\title{
Solomon Islands Election Results
}

\author{
$1967-2013$
}

\section{Terence Wood}

May 2014

The Centre for Democratic Institutions

School of International, Political \& Strategic Studies

ANU College of Asia and the Pacific

Australian National University

Canberra ACT 0200

Telephone: +61261253825

URL: http://www.cdi.anu.edu.au/

$\overline{\text { VI }}$ centre for democratic institutions 



\section{About this Document}

This book contains a record of Solomon Islands' electoral history from 1967 to 2013 . The first section provides background and some basic analysis of the results of elections for Solomon Islands' national parliament. The second section contains election results, by year and electorate, for every general election from 2010 to 1967 . The third section covers election results, by year and electorate, for every by-election for which election results still exist (some by-election results have been lost). An appendix at the end of the book provides details on current electorates and a map of Solomon Islands electorates.

Please note that the data in the results tables are not official election results. Sometimes they have come from newspaper reports and other reporting as well as the Solomon Islands Gazette (the country's official parliament gazette). You can find (most) official election results in the Solomon Islands Gazette. Results presented in this book have been checked back to source data but we cannot guarantee the original sources were accurate in every instance.

A PDF version of this document, as well as election results in Excel and other formats can be downloaded from: http://www.cdi.anu.edu.au/

Questions about the document and data should be emailed to Terence Wood:

terence.wood@anu.edu.au

\section{About the Centre for Democratic Institutions}

The Centre for Democratic Institutions (CDI) is a leading centre for policy analysis and engagement on democratic governance in South-East Asia and the Pacific. Situated in the State, Society and Governance in Melanesia Program (SSGM) in the Australian National University's College of Asia and the Pacific, our mandate is to support democratic processes in the region through engagement with current policy debates regarding democracy and political governance, and to facilitate partnerships between Australia and our close neighbours through knowledge and skills sharing.

We are committed to supporting functioning electoral processes and parliamentary systems through collaborations with democratic institutions and democratic stakeholders in the region. CDI harnesses Australian and regional expertise in democratic practice, governance and institutional development to facilitate the transfer of knowledge and skills between democratic practitioners. We conduct tailored training courses and support a program of capacity-building activities for political practitioners and institutions.

CDI is interested in how democratic change influences broader processes of political and economic development, and participation in political processes, particularly that of women. CDI's relationship with SSGM allows it to draw on current research to inform its own analysis and to enhance the effectiveness of its programming and policy engagement. For example, CDI is drawing on evidencebased knowledge of the challenges faced by woman political candidates in Melanesia to develop new strategies for supporting increased representation of women in political systems. 



\section{Acknowledgements}

We are grateful to Jon Fraenkel, Harry Greenwell and lan Frazer whose election and election-related data were useful in the creation of the results database. We are particularly grateful to the staff of the Solomon Islands Electoral Commission, the Solomon Islands Parliamentary Library, and the Solomon Islands National Archive, who were very helpful in assisting with efforts to collect results data. 



\section{Table of Contents}

Trends and Key Features of Solomon Islands Elections Results .................................................. 1

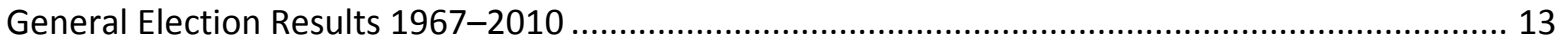

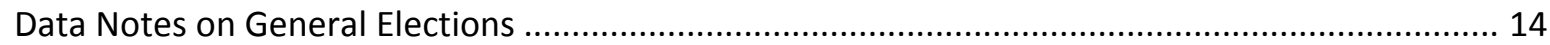

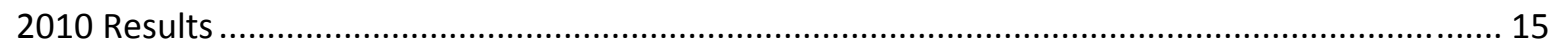

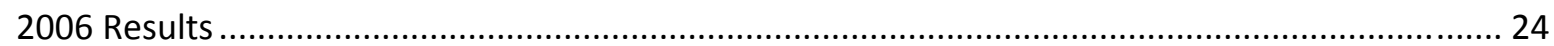

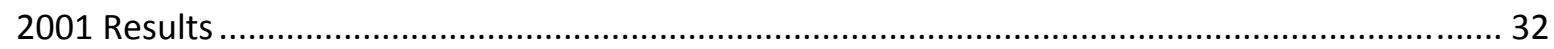

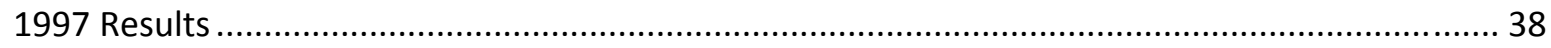

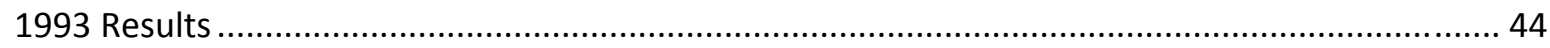

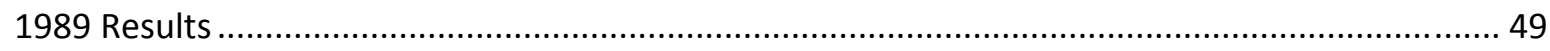

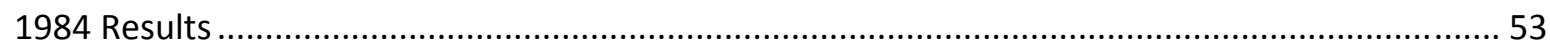

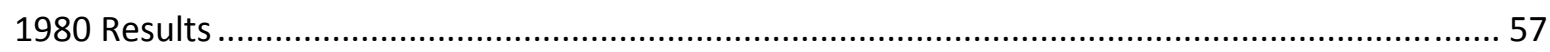

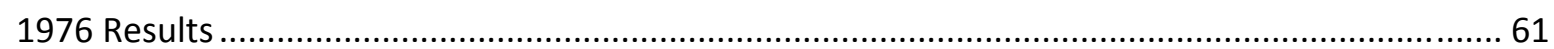

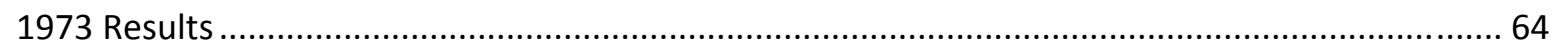

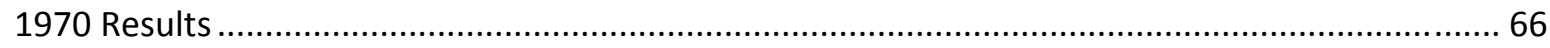

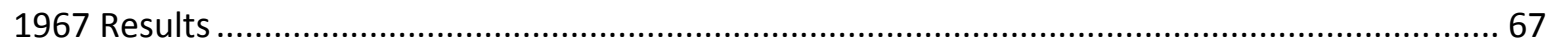

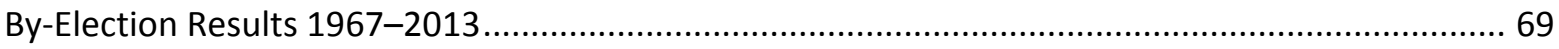

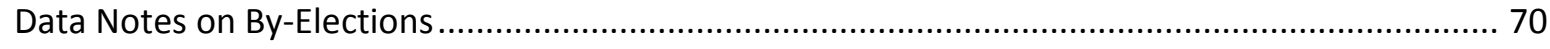

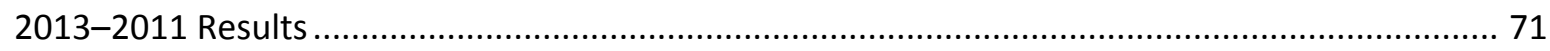

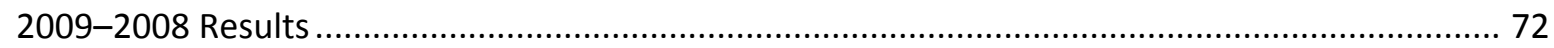

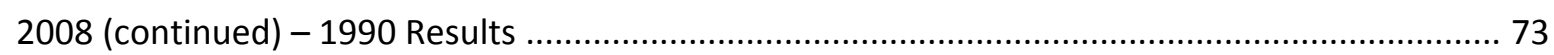

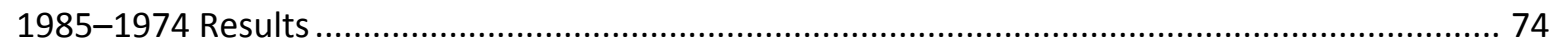

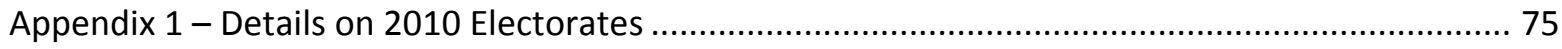

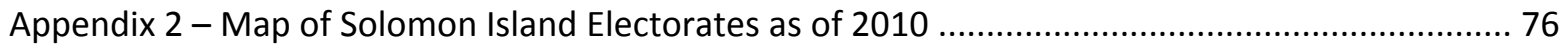





\section{Trends and Key Features of Solomon Islands Elections Results}

In 1967 Solomon Islands held its first national, mass suffrage, parliamentary elections. For the first time, voters across the British colony had a direct say in the election of 13 members of the colonial Legislative Council (Moore 2013). ${ }^{1}$ In between 1967 and the country's independence in 1978, Solomon Islands held three further general elections. Solomon Islands held its first national election as an independent nation in 1980. Between 1980 and the time of writing (May 2014) it has held eight general elections (1980, 1984, 1989, 1993, 1997, 2001, 2006 and 2010). Its ninth general election is scheduled to be held towards the end of 2014.

The results from these elections, who stood and how many votes they won, have become very hard to find. The National Archive has some and the Parliamentary Library has some in gazettes, but others exist only in copies of old newspapers kept by academics. The purpose of this book is to bring Solomon Islands election results together in one place so that future researchers and future generations of Solomon Islanders can access data from the country's founding electoral history.

The book is in three parts. The first section provides background on Solomon Islands elections including electoral rules and other aspects of the country's electoral system. It also describes the key features and trends of Solomon Islands' electoral history. The second section lists election results, by year and electorate, for every general election from 2010 to 1967 . The third section provides election results, by year and electorate, for every by-election where results were available (results were not available for all by-elections). An appendix at the end of the book contains a map of Solomon Islands electorates and details on current electorates.

Please note that the data in the results tables are not official election results. Sometimes they have come from newspaper reports and other reporting as well as the Solomon Islands Gazette. You can find (most) official election results in the gazette. Results presented in this book have been checked back to the sources they were gathered from, but we cannot guarantee the original sources were 100 per cent accurate in every instance.

\section{Electoral Rules, Elections and Electorates}

National elections in Solomon Islands are held using a single member district plurality (or 'first past the post') voting system (a system inherited from the United Kingdom, which ran the country's first pre-independence elections). Since 1997 the country has had 50 electorates, each of which sends

\footnotetext{
${ }^{1}$ There had been one previous election (in 1964) in which voters voted in Honiara, while the rest of the country used an electoral college system in which local councillors selected their parliamentary representatives. In 1967 the electoral college system was continued in the Eastern Outer Islands electorate; however, in the rest of the country voters, not members of an electoral college, chose. In addition to elected members there were also 15 un-elected members of the 1967 Legislative Council.
} 
one member of parliament (MP) to the national parliament (Steeves 2001, p. 799-800). ${ }^{2}$ The candidate who wins the plurality of votes in an electorate becomes its MP. Nationwide general elections are held approximately every four years. Intermittent by-elections have also taken place upon the death or removal, usually via court ruling, of MPs from office during the electoral term (Moore 2013; Steeves 2001).

Given they are held in an environment of low administrative capacity, and across a challenging geography, recent Solomons elections (particularly those in 2010) have been generally well run (Commonwealth Secretariat 2010). Observer teams and a system of open vote counting which permits candidates' agents to scrutinise the counting process have meant that election results, at least in recent years, have been mostly free of major wrongdoing directly involving the mechanics of the electoral process itself (Commonwealth Secretariat 2010; East-West Center 2010; Pacific Islands Forum Secretariat 2010). However, outside the formal electoral process problems with vote-buying are significant and some voters face at least tacit coercion (Wood 2014).

Elections are peaceful for the most part. Brawls between the supporters of rival candidates are not unheard of and occasional incidents such as the burning of ballot boxes have taken place, yet voting has usually been free of serious large-scale violence (Commonwealth Secretariat 2006; Commonwealth Secretariat 2010; Nanau 2011, p. 508). ${ }^{3}$

The only major blight on the operation of recent national elections has been the electoral roll, which contains many more voters than could possibly exist (Commonwealth Secretariat 2006;

Commonwealth Secretariat 2010; Kelly 2010; Paternorte and de Gabriel 2010). The 2010 roll had 448,149 registered voters, which contrasts with an estimated voting-age population of 281,161 (estimated on the basis of projections from 2009 census data).

Figure 1 charts Solomon Islands elections since independence and shows the number of registered voters, the total number of votes cast, and the estimated voting-age population. General election years are shown as dashed vertical lines. The figure also offers a sense of voter turnout. While turnout has been nominally low in recent elections (only 53 per cent of registered voters in 2010), when calculated as a proportion of the estimated voting-age population, turnout is actually fairly high (85 per cent in 2010).

\footnotetext{
${ }^{2}$ In the first election in 1967 there were 14 electorates, in 1970 there were 17 , in 1973 there were 24. From 1976 to 1993 there were 38 electorates. This increased to 47 in 1993 and to 50 in 1997.

${ }^{3}$ Sanga (2005) describes small-scale post-election violence in the East Malaita constituency after the 2001 elections, and Fraenkel (2008) and Allen (2008) note that there was considerable voter intimidation in some electorates during the 2001 elections, which took place in the midst of the Tensions. More subtle voter coercion also takes place at times. Yet large-scale election-related conflict as occurs in many developing countries, including neighbouring Papua New Guinea, has not been a feature of Solomon Islands elections.
} 
Figure 1 - Total votes, registered voters, and estimated voting-age population, 1980-2010

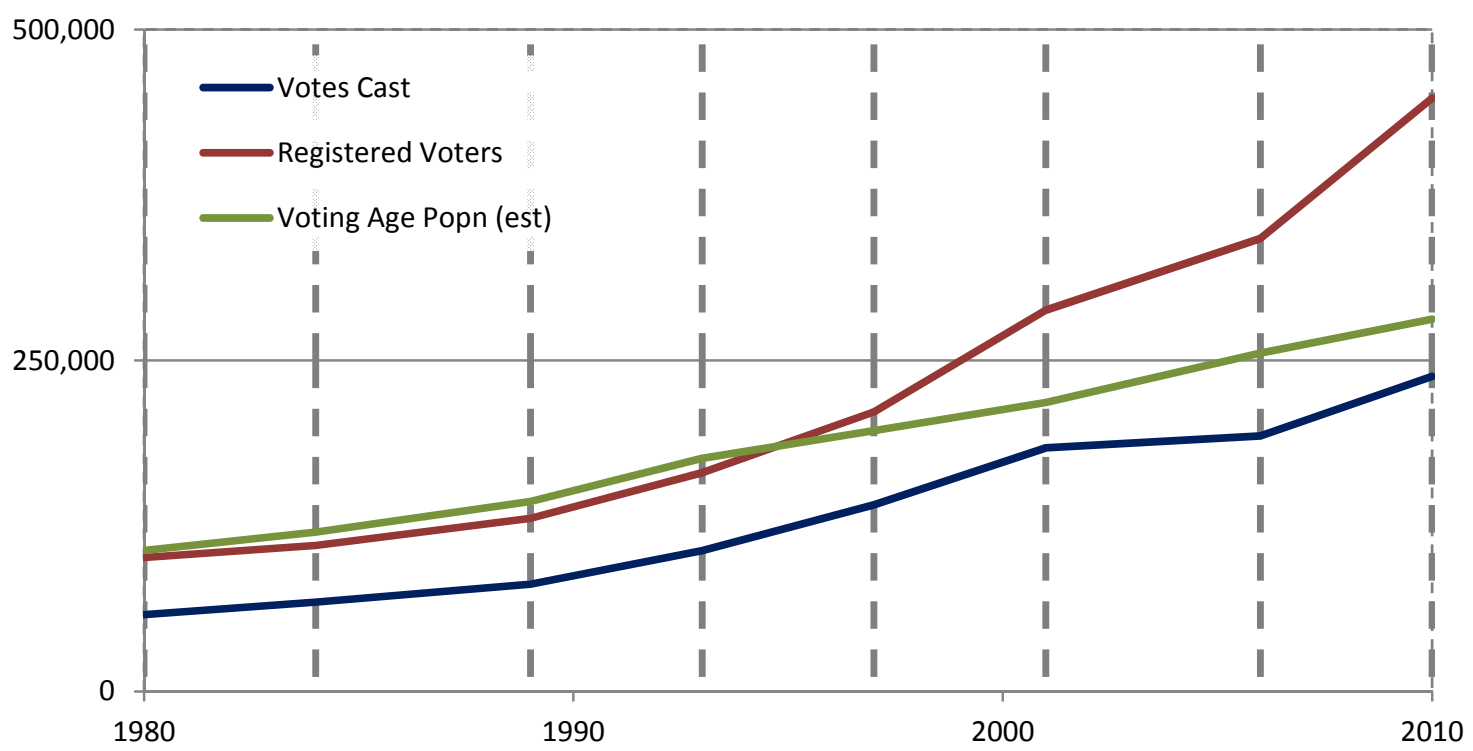

Sources: Data from election results database, calculations from censuses, and Steeves (2001) for registered voters in 1984.

\section{Candidate Numbers and Winner Vote Shares}

In the typical electorate, elections are enthusiastically contested, with numerous candidates vying for voter support. The highest number of candidates to have stood in any election was 26 in the 2008 East Honiara by-election (the highest during a general election was 23 in Central Honiara in 2010). The median electorate (over all elections since independence) has had seven candidates standing in it.

Figure 2 shows the average number of candidates and average effective number of candidates (ENC, which can be thought of as an approximation of the number of competitive candidates $)^{4}$ standing in Solomon Islands general elections since independence. Two facts stand out. First, there was no significant overarching trend in candidate numbers between 1980 and 2001, although candidate numbers have increased considerably since 2001. Second, other than a very slight upturn since 2001, average ENC has not increased over time. Divergence between the number of candidates and the

\footnotetext{
${ }^{4}$ Owing to the fact that not all candidates are equally competitive, absolute candidate counts may not accurately reflect the state of competition in any particular electorate. For example, an electorate where one candidate obtains 91 per cent of votes cast while the remaining nine candidates obtain only 1 per cent each is a very different electorate from one where 10 candidates each win 10 per cent of the vote. To account for this, political scientists typically report on electoral competition using a calculated figure, the 'effective number of candidates' (ENC) (or effective number of parties: ENP). The ENC is the reciprocal of the Herfindahl-Hirschman index of candidate vote shares in an electorate, and is calculated as 1 divided by the sum of all the candidate's squared vote-shares. (Or, in equation form: $1 / \sum_{i}^{n} v i^{2}$ where $\mathrm{n}=$ the number of candidates and $v i=$ the vote share of the $i$ th candidate). In my example electorate where one candidate obtains 91 per cent of the vote and the remaining 9 candidates obtain 1 per cent each the ENC is 1.21 , close to one, reflecting the fact that only one candidate was competitive; in the electorate with 10 candidates each obtaining 10 per cent of the vote the ENC is 10 , a reflection of the fact that all 10 were equally close to winning.
} 
ENC suggests that while candidates have contested elections in increasing numbers since 2001, the number of candidates who have polled well has not risen.

Figure 2 - Average candidates and effective number of candidates, general elections 1980-2010

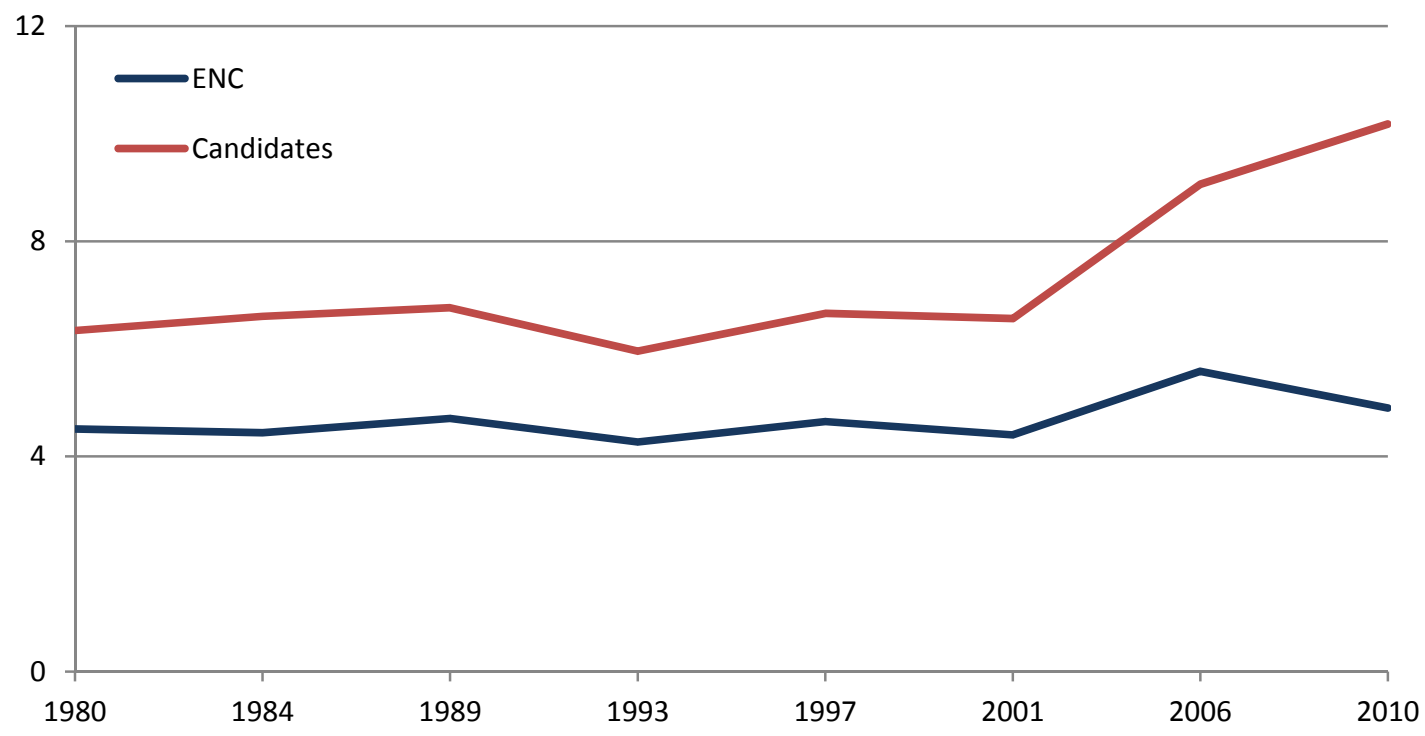

Figure 3 shows average (mean and median) winning candidate vote shares in Solomon Islands general elections since independence. As with ENC in Figure 2, there appears to be no strong trend in winning candidate vote shares. The graph also shows that the average winner of a Solomon Islands election does not win more than 50 per cent of the vote, although wins with more than 50 per cent of the vote do occur in a minority of cases (in 2010 eight winning candidates won with more than 50 per cent of votes cast in their electorates).

Figure 3 - Mean and median winner vote share, general elections 1980-2010

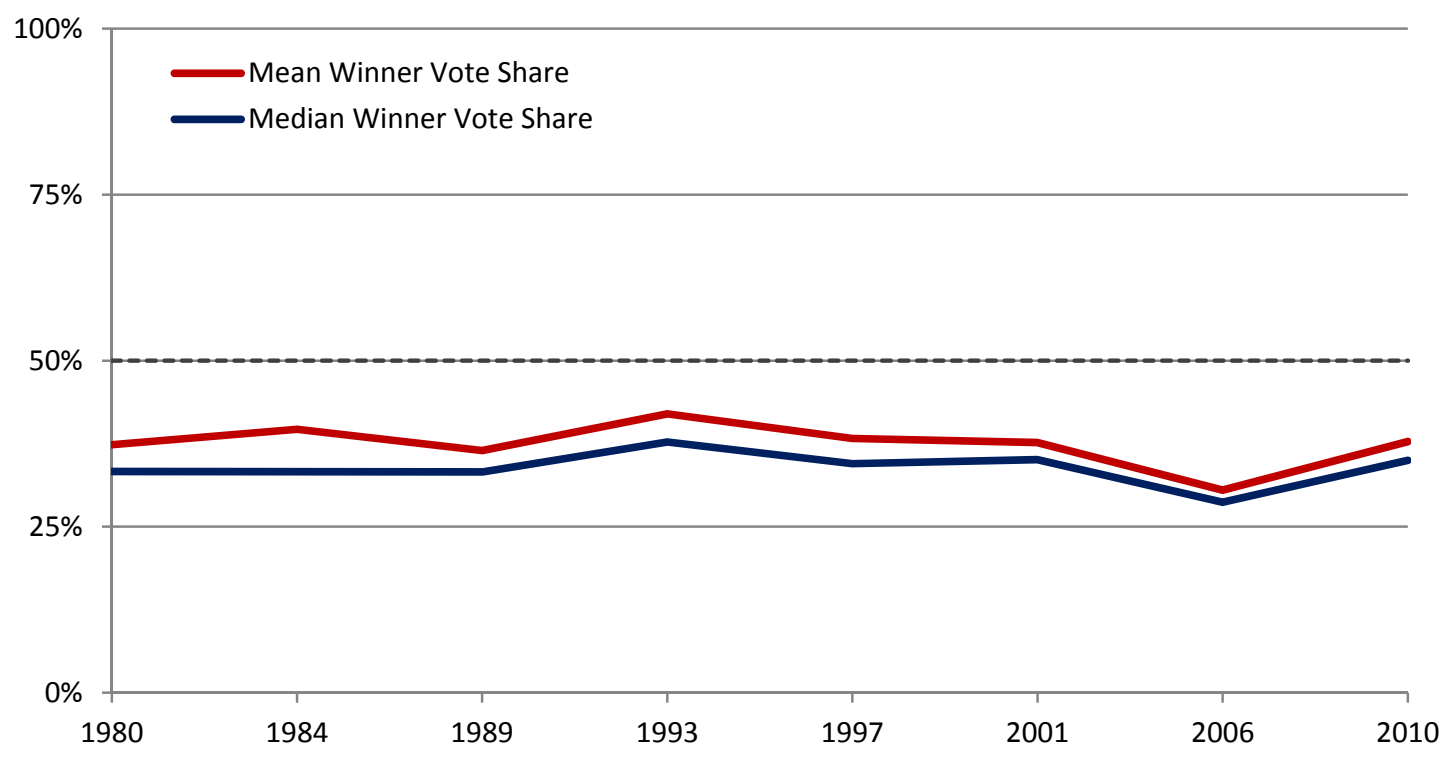


Although Solomon Islanders are enthusiastic competitors in elections, success itself, either in the form of winning, or even merely winning a significant slice of electoral support, is hard to come by. Over the eight general elections Solomon Islands has had since independence, approximately 1,700 different people have stood as candidates. Of these only 196 have ever won. Figure 4 is a histogram based on the vote share of all candidates who stood in elections from 1980 until 2011. The $X$ axis shows groupings of vote shares, the $Y$ axis shows the number of candidates falling into that grouping. For example, the first bar on the left shows that more than 800 candidates have stood and won less than 5 per cent of the votes in their electorate. The steady fall in the height of the bars from left to right reflects the fact that most candidates in Solomon Islands elections win low vote shares. The plurality have won under 5 per cent of the votes cast in their electorate; the majority less than 10 per cent.

Figure 4 - Histogram of candidates' vote shares, all candidates, all elections 1980-2012

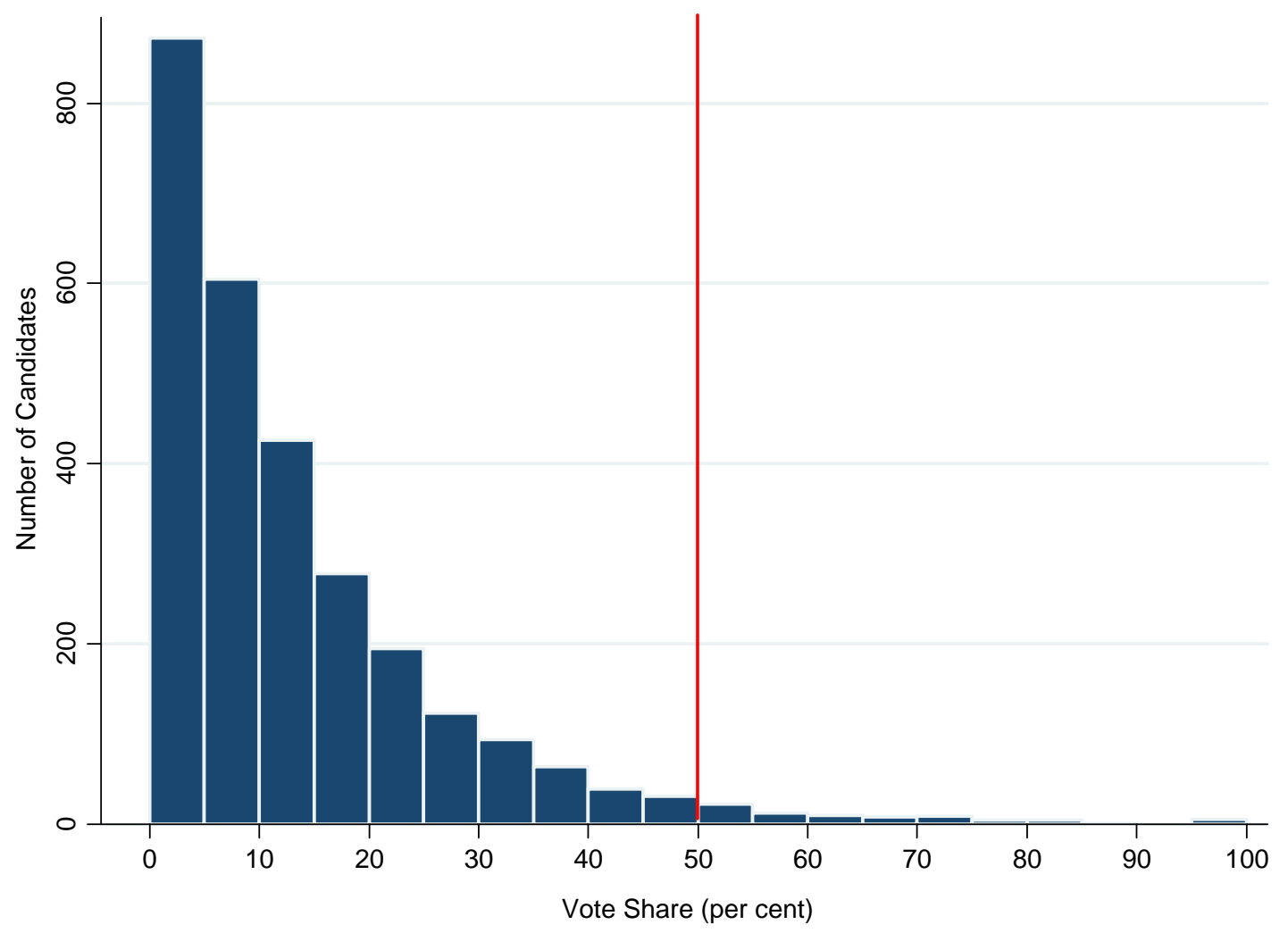

\section{Women Candidates}

The number of women candidates who have stood in national elections in Solomon Islands since 1980 is shown in Figure 5. Both the absolute number of candidates who were women and the percentage of all candidates who were women are shown. 
Figure 5 - Women candidates (as absolute number on right axis; as percentage of all candidates on left), $1980-2010$

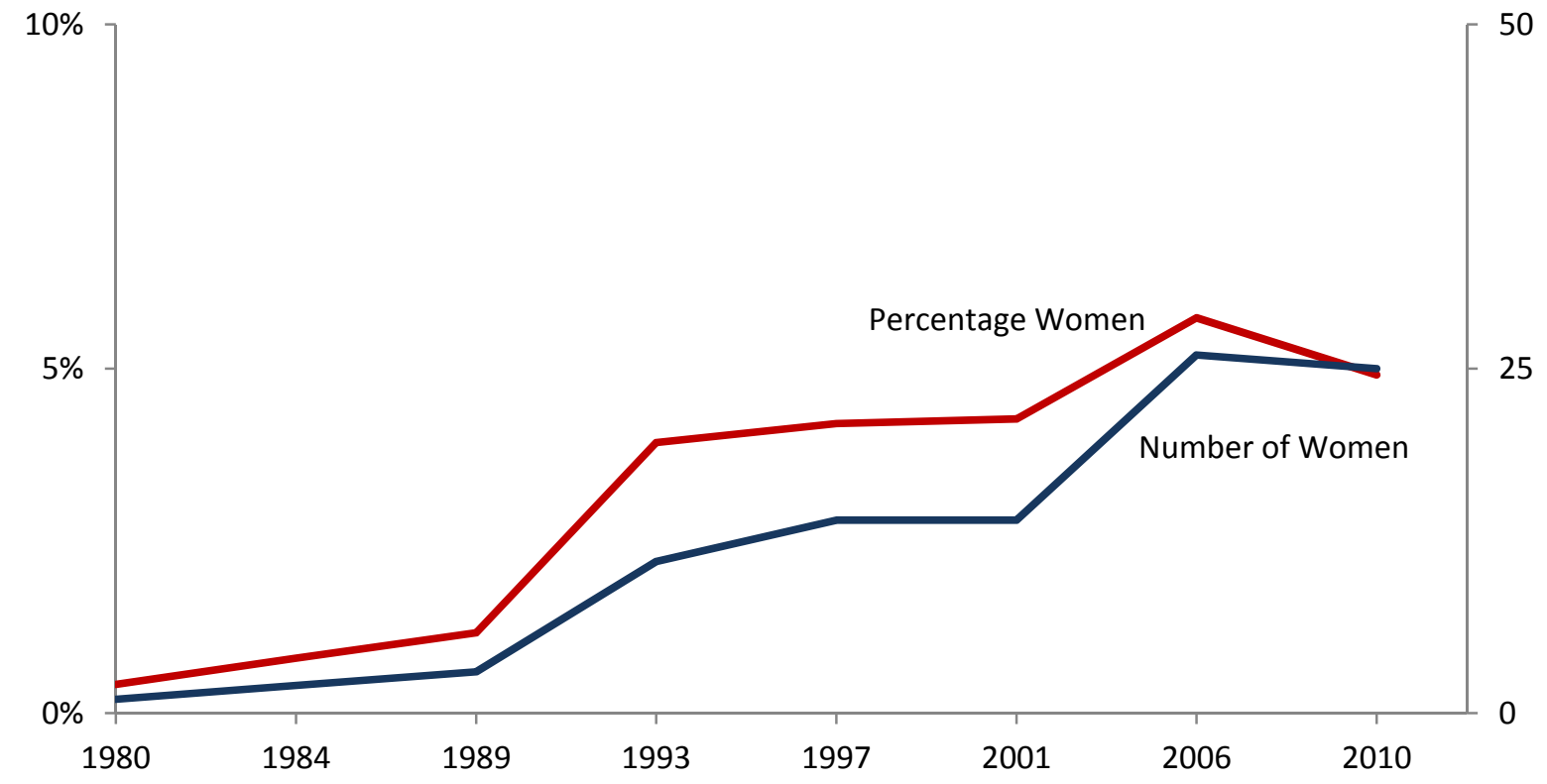

Over the eight general elections Solomon Islands has held since independence, a total of 72 different women have stood in general elections (an additional three women stood in elections preindependence). As Figure 5 shows, numbers of women candidates increased up until 2010, when there was a small decrease. Only two women - Hilda Kari and Vika Lusibaea - have won nationallevel elections in Solomon Islands since 1980.

\section{Incumbent Turnover Rates}

Tenure for those few candidates lucky enough to win is often short. Since the first postindependence election, on average nearly half (47 per cent) of those incumbent MPs who have defended their seats have lost them. ${ }^{5}$ Figure 6 shows the percentage of incumbent MPs who contested and lost in general elections.

\footnotetext{
${ }^{5}$ On average, across all general elections since independence 91.4 per cent of MPs have defended their seats. Although comprehensive data do not exist explaining instances where MPs have not defended seats, instances for which there are data suggest voluntary retirement is far from the only cause. A number of MPs have died in office, and several have gone to prison while in office. And while death and imprisonment ought to trigger byelections, when a general election is close the seat in question has often simply been held vacant until the general election. One cause of incumbent non-defence present in some other countries does not occur in Solomon Islands. Owing to the weakness of political parties in Solomon Islands (discussed more below), there is nothing akin to a party pre-selection process in Solomon Islands electorates. If an incumbent wishes to stand, and is alive and not prevented from doing so by problems with the law, they are able to.
} 
Figure 6 - Incumbent turnover as a percentage of contesting incumbents, general elections 19802010

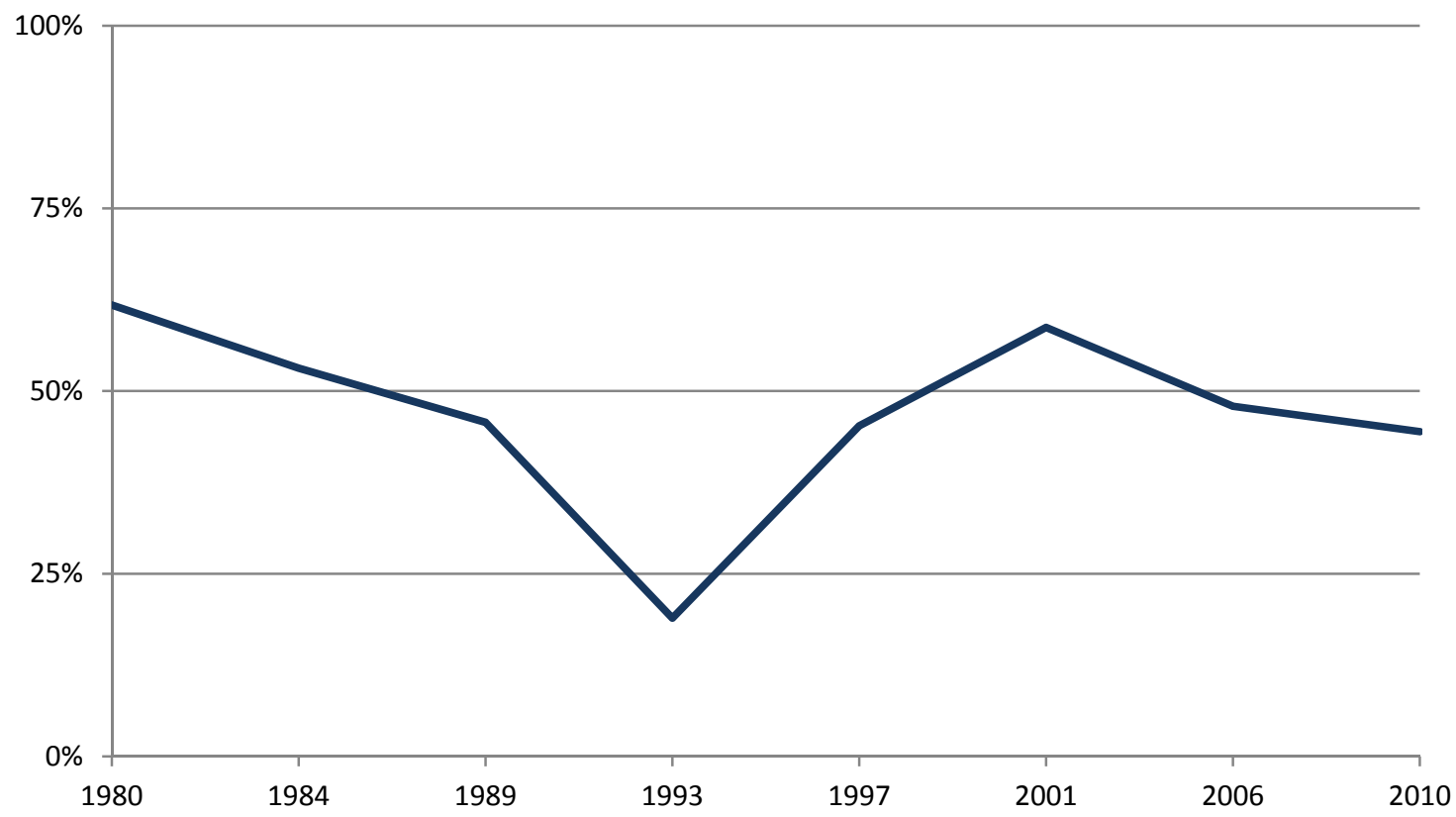

Notes: the numerator in the calculation reflected in this graph is the number of incumbent MPs who contested and lost in each general election; the denominator is the number of incumbent MPs who contested.

As can be seen in Figure 6 there is variation between elections but no clear trend. Turnover rates were at their highest in the first post-independence election in 1980, but they were nearly as high again much more recently in 2001. The lowest levels of incumbent turnover occurred in 1993, an election which saw the introduction of a dedicated constituency development fund (paid for with Taiwanese aid) provided to sitting MPs, which they could spend, effectively at their own discretion, within their electorates (Fraenkel 2011). ${ }^{6}$ Ostensibly this was meant to be a tool to assist development at the local level, yet it clearly has considerable use as a tool of patronage and, from that, is a potential source of electoral advantage. The number of electorates also rose from 38 to 47 in 1993, which meant that many sitting MPs found themselves defending smaller electorates. These two factors are the most likely causes of low turnover rates in 1993, with subsequent years seeing a return to equilibrium of sorts as aspiring challengers realised that smaller electorates meant fewer votes required to win. At the same time, voters worked out that largess in the form of constituency funds was not something solely the domain of the sitting MP and would likely flow, and possibly flow more, were that MP to be defeated.

\footnotetext{
${ }^{6}$ Something akin to these funds pre-dated 1993; however, previous funds were smaller and appeared to be less amenable to patronage spending.
} 


\section{Differences Between Electorates}

Thus far the electoral statistics summarised have mostly taken the form of national averages or aggregates, yet buried within these country-level composites is considerable variation between electorates, as well as variation over time within individual electorates.

Figure 7 is a histogram of winning candidate vote shares from all post-independence elections.

Figure 7 - Winner vote shares, all elections 1980-2010

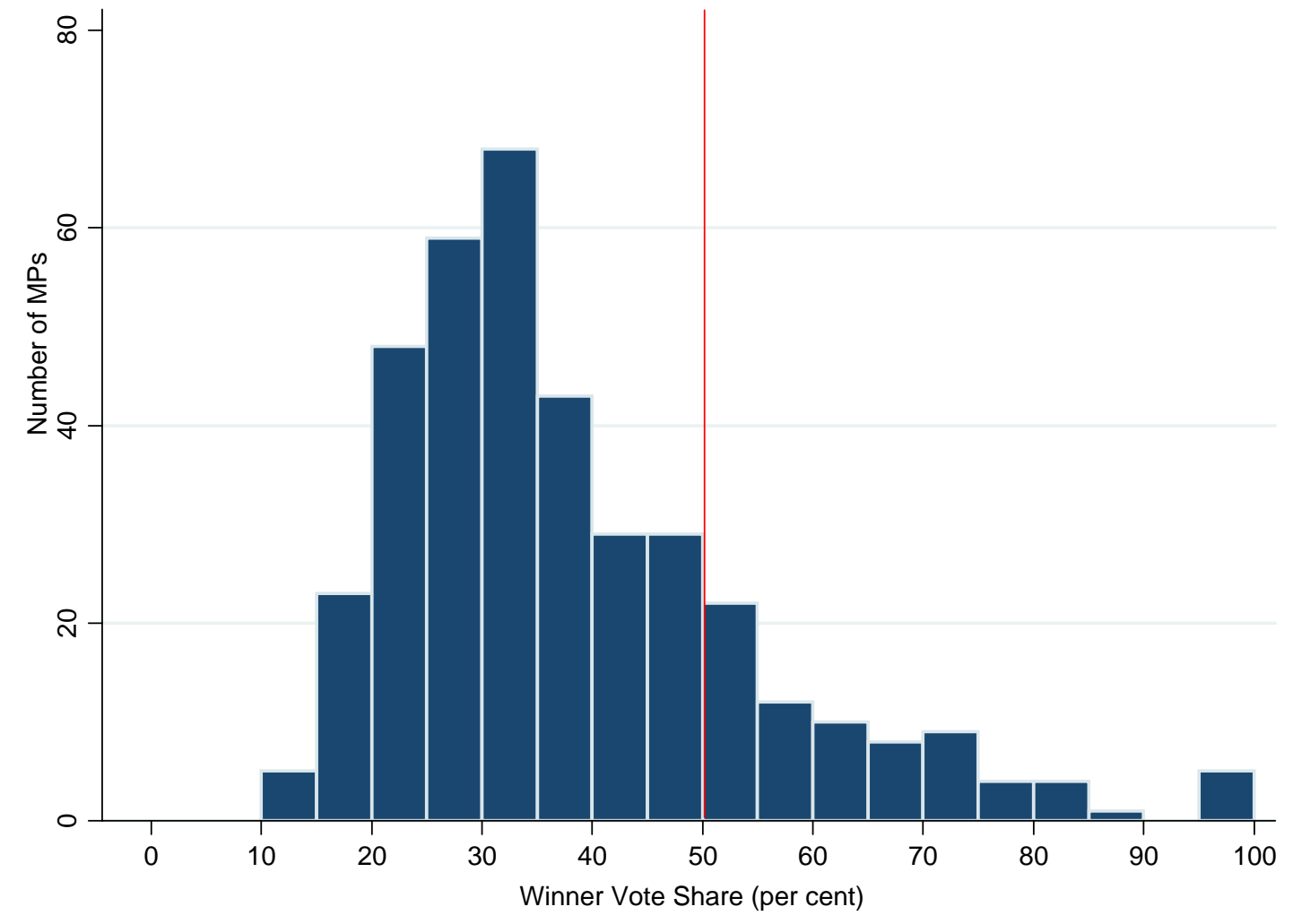

The lowest winning candidate vote share was that of Ben Foukona in Lau/Mbaelelea in 1984, who won with only 10.7 per cent of the vote. The highest winner vote share, setting aside the few instances where candidates have effectively won 100 per cent because they stood in uncontested elections, was that of Victor Ngele, who won 87 per cent of the vote in South Guadalcanal in 1993. In between these extremes, as the histogram illustrates, individual election wins have occurred across a very wide range of vote shares.

Focusing on the 2010 general election, Figure 8 is a scatterplot showing the number of candidates who stood and the percentage vote share of the winning candidate for each electorate. The red line on the chart is the (ordinary least squares) line of best fit. The two- or three-letter electorate codes are mapped to electorate names in the appendix. 
Two aspects of the graph are interesting: first, there is a lot of variation both in the number of candidates standing and the votes won by the winning candidate; second, on average, electorates where there are more candidates are also the electorates where the winner wins with lower vote shares. It is much harder to win with a large vote share when you are contesting against numerous candidates. The winner in Central Honiara in 2010, where 23 candidates stood, achieved just under 15 per cent of the vote. In North New Georgia, on the other hand, there were only three candidates and the winner won nearly 74 per cent of all votes cast.

Figure 8 - Candidate numbers and winner vote shares, 2010 general election

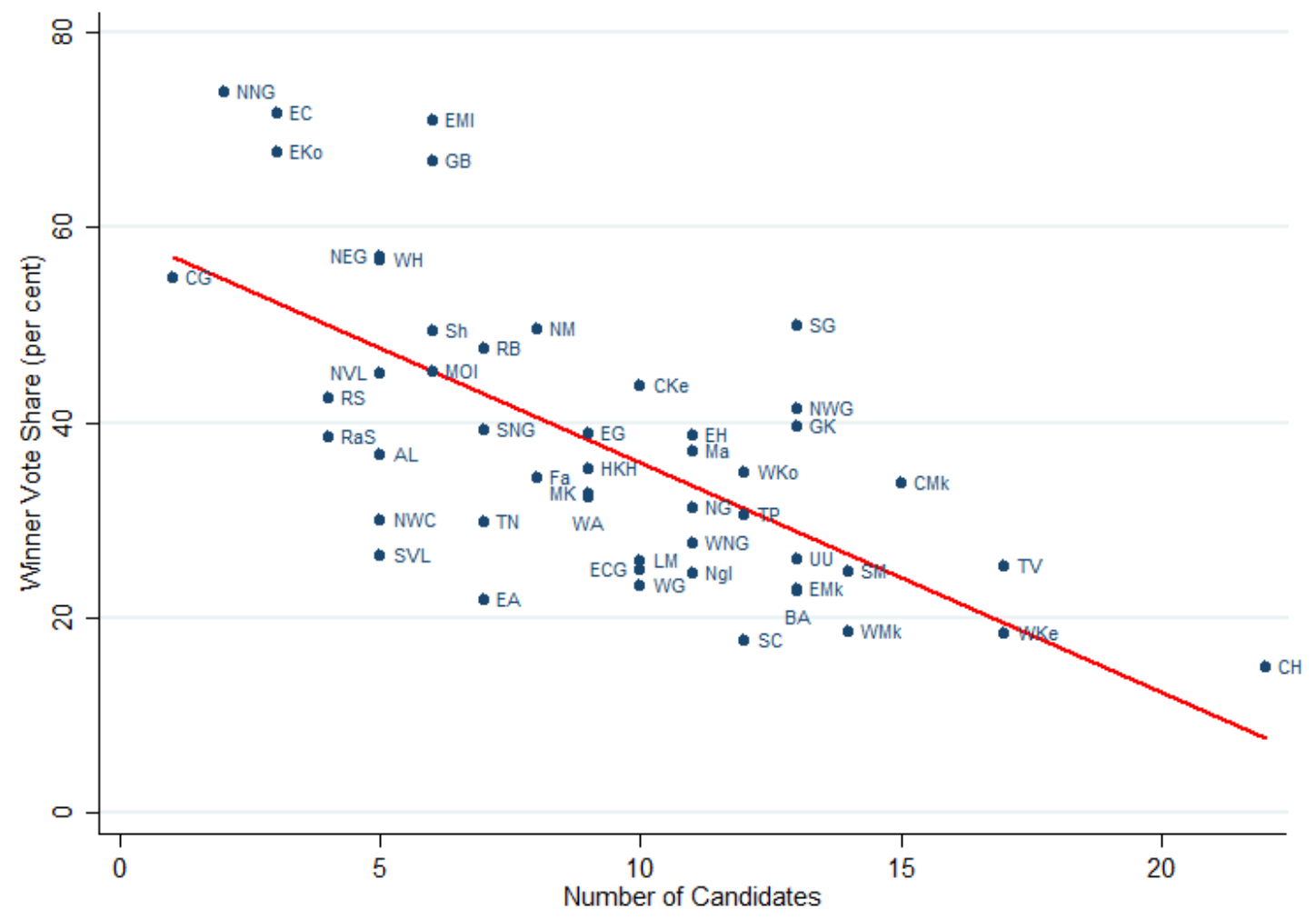

Interestingly, variance in candidate numbers or winning candidates' vote shares is not predominantly the product of between-province differences. It is true that, in terms of raw candidate numbers, the provinces of Malaita and Honiara have had more candidates standing in their electorates on average. But they also have electorates that contain, on average, more people, and this, rather than provincial culture, appears to be the main determinant of candidate numbers.

\section{Differences Within Electorates Over Time}

There is considerable variation in candidate numbers, effective numbers of candidates, and winning candidate vote shares within the same electorates over time. Figure 9 provides an example of this, plotting the number of candidates and the winning vote share over time for Central Guadalcanal electorate since independence. In 1997, eight candidates stood; by 2010 there were only two. In 
1984 the winner won with less than 30 per cent of votes cast. In the 2009 by-election the winner won almost 60 per cent of the votes cast.

Figure 9 - Number of candidates and winner vote share for Central Guadalcanal, 1980-2010

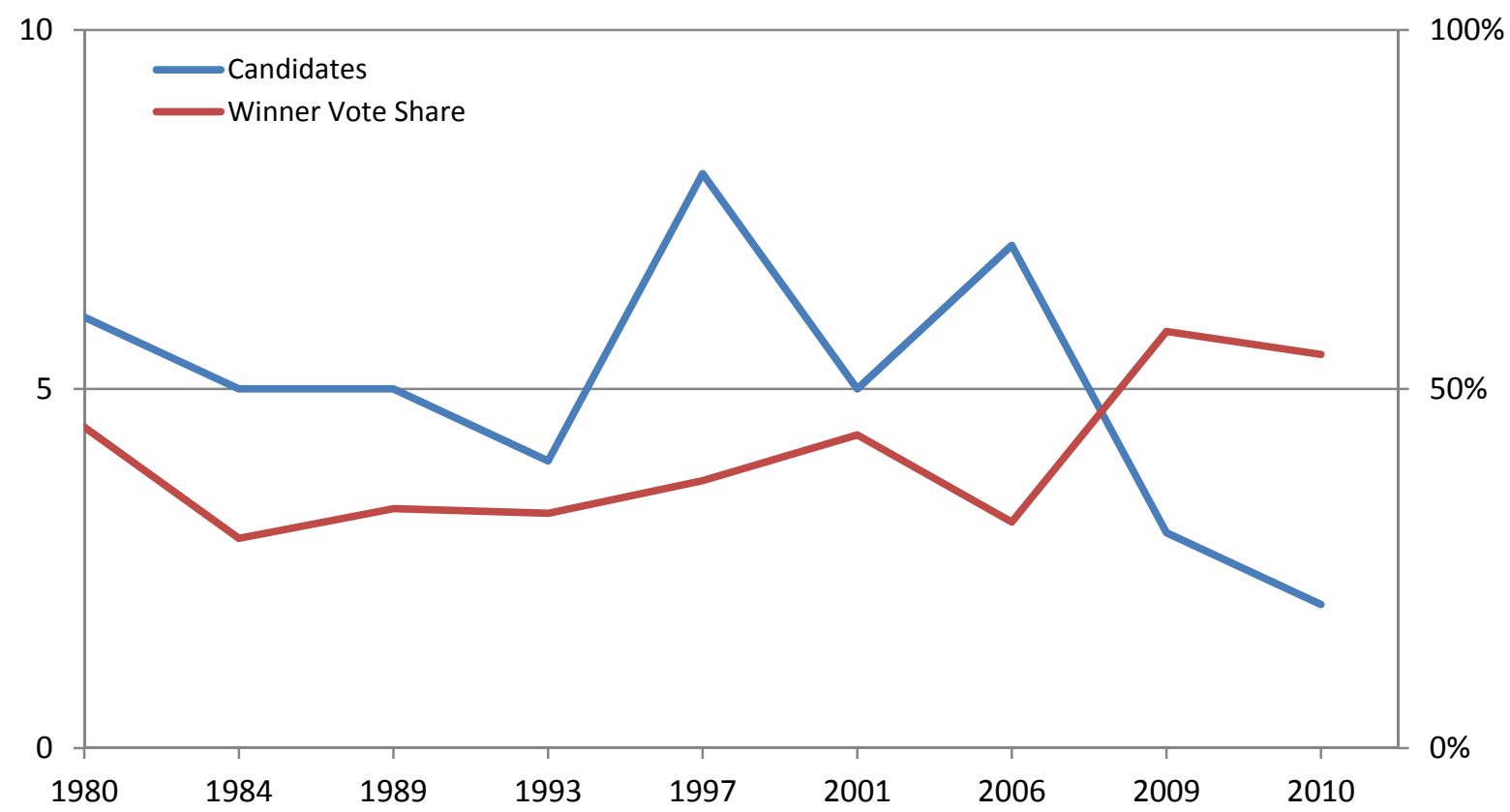

\section{Members of Parliament}

One aspect of electoral politics that is common to almost all electorates and which has remained unchanged over elections is the difference between the backgrounds of members of parliament and their constituents. Whereas around one-quarter of Solomon Islanders (26 per cent, as per 2009 census data) described themselves as employers or employees, all of the MPs in the 2010 parliament for whom researchers were able to obtain source data (49 out of 50) had worked in the formal economy before joining politics. Business backgrounds or employment in the civil service were the most common pre-parliamentary careers among MPs. Less frequent but still relatively common were MPs who had worked as teachers or school principals, and former provincial parliament MPs. Significantly, there were no subsistence farmers or people who made a living from selling produce at local markets serving as MPs in 2010. Even in 1980, while the makeup of parliament was different (civil servants formed a much higher share; private sector workers a much lower share), all or almost all members of parliament had worked in the formal economy before entering parliament (Corbett and Wood 2013, p. 327).

Similarly, according to the 2009 census, only 23.3 per cent of Solomon Islanders aged over 12 years had had some secondary education (Solomon Islands National Statistics Office 2012, p. 2). Yet, of those MPs in the 2010 parliament for whom we were able to obtain information (46 out of 50) 91.3 per cent had received some secondary education. Forty-five per cent of MPs in the 2010 
parliament had undertaken tertiary study, compared to only 4.4 per cent of Solomon Islanders aged over 12 (Corbett and Wood 2013, p. 325).

While MPs tend to come into their roles with the benefit of higher than average levels of education, and experience either as civil servants or working in the private sector, owing to the high incumbent turnover rates, the number of MPs who have political experience born of long stays in parliament is quite low. Figure 10 shows the composition of post-independence Solomon Islands parliaments broken down by the proportion of serving MPs' length of parliamentary tenure.

On average across all parliaments since independence, almost half (49 per cent) of MPs have been first-term MPs and over three-quarters (76 per cent) have been either first- or second-term MPs. In 2010, 84 per cent of MPs were serving either their first or second term in parliament.

Figure 10 - Solomon Islands parliaments by MP tenure, 1980-2010

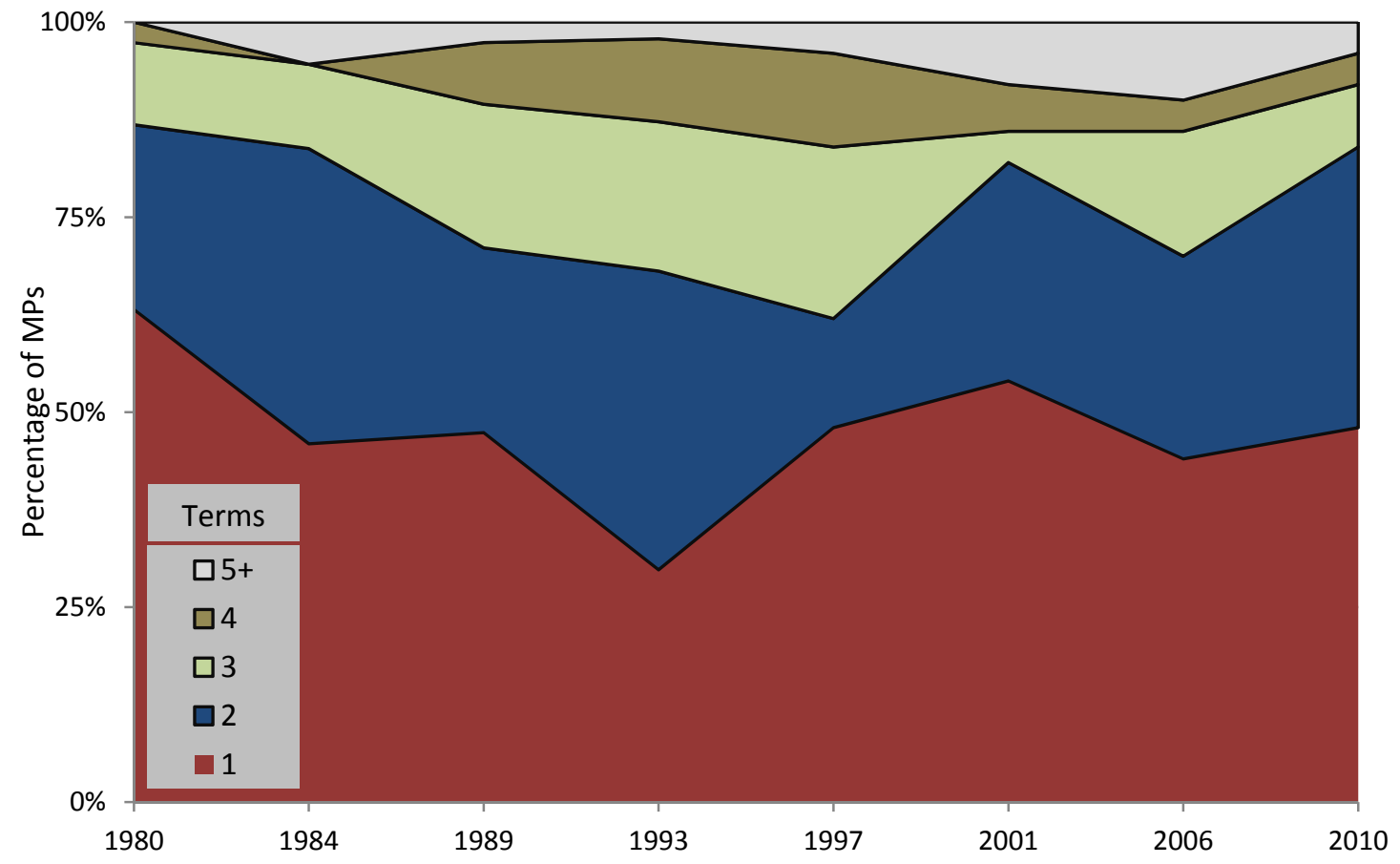




\section{References}

Allen, M. 2008. Politics of disorder: the social unrest in Honiara. In: Dinnen, S. \& Firth, S. (eds.)

Politics and State-building in Solomon Islands. Canberra: Asia Pacific Press: 39-63.

Allen, M. 2011. The Political Economy

Commonwealth Secretariat 2006. Solomon Islands General Election Report of the Commonwealth Observer Group. Commonwealth Secretariat.

Commonwealth Secretariat 2010. Report of the Commonwealth Observer Group: Solomon Islands National Parliamentary Elections. Commonwealth Secretariat.

Corbett, J. and T. Wood 2013. Profiling Politicians in Solomon Islands: Professionalisation of a Political Elite? Australian Journal of Political Science 48(3):320-34.

East-West Center 2010. Asia Pacific Democracy Partnership Election Observation of the 4 August 2010 National Parliamentary Elections Solomon Islands: Preliminary Statement. Honolulu: East-West Center. <http://www.eastwestcenter.org/news-center/news-releases/solomonislands-election-observers-issue-statement>, viewed 20/5/2014.

Fraenkel, J. 2008. The Impact of RAMSI on the 2006 Elections. Political Science, 58(2): 63-85.

Fraenkel, J. 2011. The Atrophied State: A Supply-Side perspective on Politician 'Slush Funds' in Western Melanesia. In R. Duncan (ed.) The Political Economy of Economic Reform in the Pacific. Manila: Asian Development Bank, 298-311.

Kelly, N. 2010. Electoral Democracy in Post-Conflict Melanesia: The 2010 Bougainville and Solomon Islands Elections. CDI Policy Paper Series on Political Governance (2):1-29.

Moore, C. 2013. Indigenous Participation in Constitutional Development. The Journal of Pacific History 48(2):162-76.

Nanau, G.L. 2011. Solomon Islands. The Contemporary Pacific 23(2):504-12.

Pacific Islands Forum Secretariat 2010. Report of the Pacific Islands Forum Secretariat's Election Observer Team to the 2010 General Elections for the Solomon Islands. Suva: Pacific Islands Forum Secretariat.

Paternorte, M. and J.A. de Gabriel 2010. Final Report: European Union Electoral Expert Mission to the Solomon Islands 2010. European Union.

Sanga, K. 2005. Digging Deeper: Resolving Conflict at a Community Level. In: Henderson, J. \& Watson, G. (eds.) Securing a Peaceful Pacific. Christchurch: Canterbury University Press: 442452.

Solomon Islands National Statistics Office 2012. Solomon Islands Population and Housing Census 2009: Basic Tables and Census Description. Statistical Bulletin. Honiara: Statistics Office, Ministry of Finance.

Steeves, J.S. 2001. Solomon Islands. In D. Nohlen, F. Grotz and C. Hartmann (eds). Elections in Asia and the Pacific: A Data Handbook. Oxford: Oxford University Press, 795-808.

Wood, T. 2014. Ties that Unbind? Ethnic Identity, Social Rules and Electoral Politics in Solomon Islands. PhD thesis, The Australian National University. 
General Election Results 1967-2010 


\section{Data Notes General Elections}

Data are from the following sources:

2010 the Solomon Islands Gazette

2006 the Solomon Islands Gazette

2001 the Solomon Star Newspaper (Monday 10 December 2001)

1997 the Solomon Nius (August 1997)

1993 the Solomon Islands Gazette

1989 the Solomon Islands Gazette

1984 the Solomon Islands Gazette

1980 Newspaper reporting (the name of the paper the results copy is taken from is not clear)

1976 the Solomon Islands Gazette

1973 the Solomon Islands Gazette

1970 the Solomon Islands Gazette

1967 the Solomon Islands Gazette

Spelling is not standardised in Solomon Islands. To allow for comparisons across time, names of candidates have been standardised. This was done carefully, but could potentially have introduced errors. Original names, spelt as reported in the source data, can be found in the data files which accompany this report on the CDI's website.

Minor redistricting occurred in 1997. Significant redistricting occurred in 1993. There was also some redistricting pre-1976.

A map of electorates (as they have been since 1997) is in the appendices of this document.

A table mapping pre-1997 (and pre 1993) electorates to current electorates can be downloaded from: http://wp.me/aSqRs-zC. Mapping for pre-1976 redistricting is not available.

Data in the following tables has been reconciled to source data. However, there may be errors in the source data. There is one error which I am aware of. These are the results for Joseph Wane in the electorate of small Malaita in 2010. Here they are reported as per the gazette; however, polling station data and interviews suggest he won 544 votes not 13 . 
General Election Results

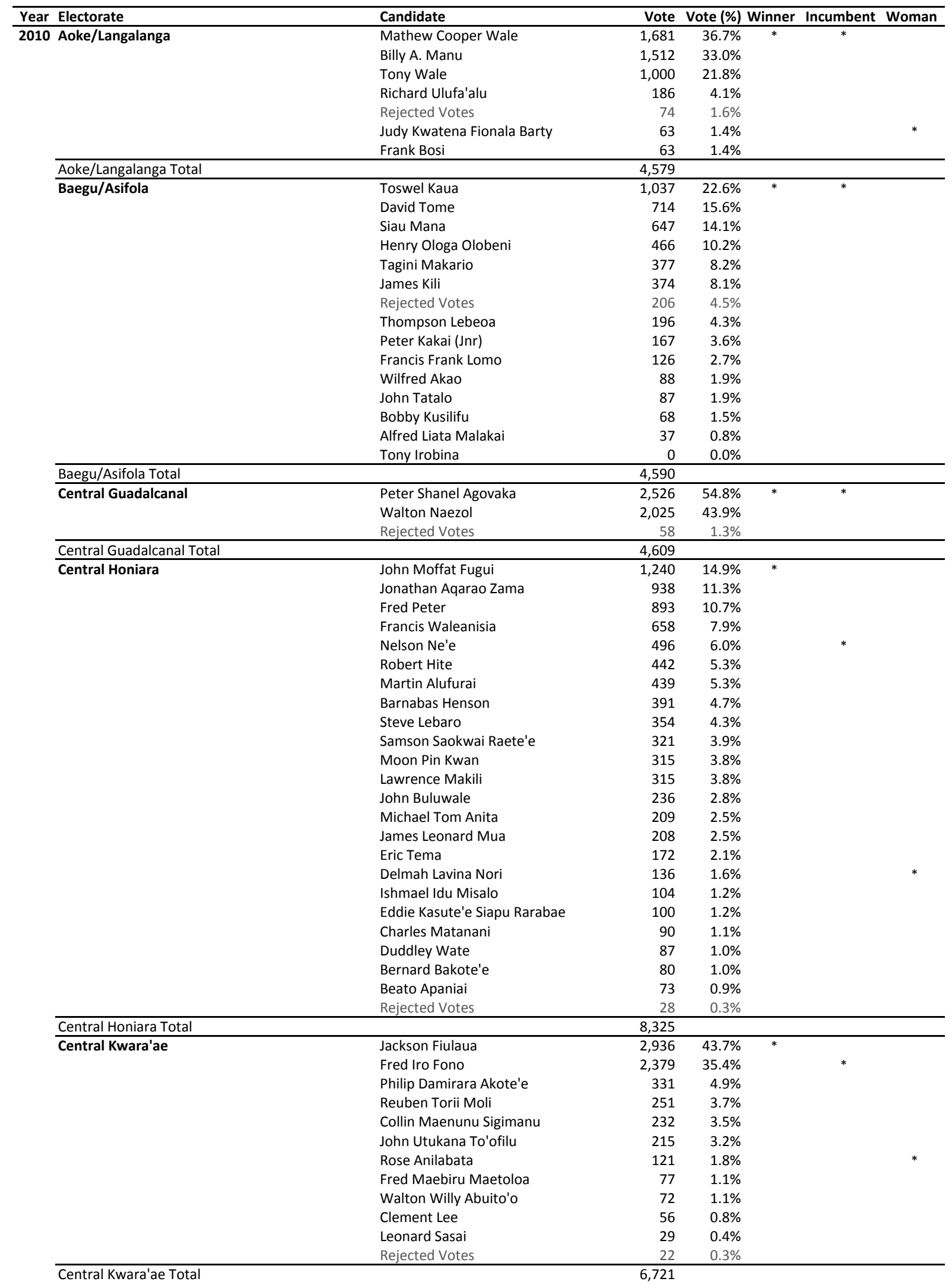


General Election Results

\begin{tabular}{|c|c|c|c|c|c|c|c|}
\hline Year & Electorate & Candidate & Vote & Vote (\%) & Winner & Incumbent & Woman \\
\hline \multirow[t]{17}{*}{2010} & Central Makira & Hypolite Taremae & 1,360 & $33.8 \%$ & $*$ & \multirow[t]{17}{*}{ 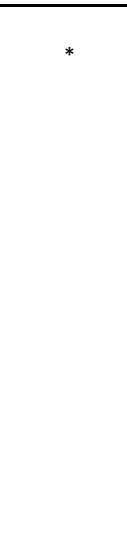 } & \multirow{17}{*}{$*$} \\
\hline & & Bernard Ghiro & 817 & $20.3 \%$ & & & \\
\hline & & Nestor Ghiro & 478 & $11.9 \%$ & & & \\
\hline & & Vkey Mansugu & 232 & $5.8 \%$ & & & \\
\hline & & Fredson Fenua & 225 & $5.6 \%$ & & & \\
\hline & & Fox Qwaina & 172 & $4.3 \%$ & & & \\
\hline & & Jack Faga & 137 & $3.4 \%$ & & & \\
\hline & & Joseph Tamuatara & 124 & $3.1 \%$ & & & \\
\hline & & Henry Hagawusia & 122 & $3.0 \%$ & & & \\
\hline & & Nesta Marahora & 121 & $3.0 \%$ & & & \\
\hline & & Paul Watoto & 65 & $1.6 \%$ & & & \\
\hline & & Thomas Nukuafi & 48 & $1.2 \%$ & & & \\
\hline & & Alfred Wato & 42 & $1.0 \%$ & & & \\
\hline & & Romano Taro & 31 & $0.8 \%$ & & & \\
\hline & & Edmund Mehare & 25 & $0.6 \%$ & & & \\
\hline & & Rejected Votes & 19 & $0.5 \%$ & & & \\
\hline & & Aaron Koroa & 8 & $0.2 \%$ & & & \\
\hline & Central Makira Total & & 4,026 & & & & \\
\hline \multirow{9}{*}{\multicolumn{2}{|c|}{ East Are' Are }} & Andrew Hanaria Keniasina & 1,000 & $21.7 \%$ & $*$ & & \\
\hline & & Aliki Tokii Ha'apio & 947 & $20.5 \%$ & & & \\
\hline & & Andrew Manepora'a & 903 & $19.6 \%$ & & & \\
\hline & & Abraham Namokari & 792 & $17.2 \%$ & & & \\
\hline & & Michael Ahikau & 628 & $13.6 \%$ & & & \\
\hline & & Brian Aonima & 274 & $5.9 \%$ & & & \\
\hline & & Joseph Hatamane Ririmae & 54 & $1.2 \%$ & & & \\
\hline & & Rejected Votes & 11 & $0.2 \%$ & & & \\
\hline & & Jerry Haipora Terenihona & 3 & $0.1 \%$ & & & \\
\hline & East Are' Are Total & & 4,612 & & & & \\
\hline \multirow{12}{*}{\multicolumn{2}{|c|}{ East Central Guadalcanal }} & Joseph Onika & 1,133 & $24.8 \%$ & * & \multirow{12}{*}{$*$} & \\
\hline & & Nollen C. Leni & 961 & $21.0 \%$ & & & \\
\hline & & Gordon Tapalia & 630 & $13.8 \%$ & & & \\
\hline & & Reuben Tovutovu & 606 & $13.3 \%$ & & & \\
\hline & & Molia Gemali & 392 & $8.6 \%$ & & & \\
\hline & & Abel Arambola & 330 & $7.2 \%$ & & & \\
\hline & & Mark Gatu & 155 & $3.4 \%$ & & & \\
\hline & & Eric Thogole & 108 & $2.4 \%$ & & & \\
\hline & & Rejected Votes & 98 & $2.1 \%$ & & & \\
\hline & & Nathaniel Mara & 75 & $1.6 \%$ & & & \\
\hline & & Job Maneka Geseni & 44 & $1.0 \%$ & & & \\
\hline & & Kamilo Kevin Gaoma & 40 & $0.9 \%$ & & & \\
\hline & East Central Guadalcanal Total & & 4,572 & & & & \\
\hline \multirow{5}{*}{\multicolumn{2}{|c|}{ East Choiseul }} & Mannaseh Sogavare & 1,913 & $71.8 \%$ & * & \multirow[t]{5}{*}{ * } & \\
\hline & & Moses Kurebose Biliki & 384 & $14.4 \%$ & & & \\
\hline & & Sheperd Lapo & 248 & $9.3 \%$ & & & \\
\hline & & Hence Vaekesa & 100 & $3.8 \%$ & & & \\
\hline & & Rejected Votes & 20 & $0.8 \%$ & & & \\
\hline & East Choiseul Total & & 2,665 & & & & \\
\hline \multirow{11}{*}{\multicolumn{2}{|c|}{ East Guadalcanal }} & Bradley Tovosia & 1,630 & $38.9 \%$ & * & & \\
\hline & & Sampson Tahuniara & 818 & $19.5 \%$ & & & \\
\hline & & Johnson Koli & 505 & $12.0 \%$ & & * & \\
\hline & & John Hue & 404 & $9.6 \%$ & & & \\
\hline & & Ezekiel Alebua & 293 & $7.0 \%$ & & & \\
\hline & & Kennedy Hoda & 168 & $4.0 \%$ & & & \\
\hline & & Henry Pechakibo & 153 & $3.6 \%$ & & & \\
\hline & & Joe Tuti Ruriti & 117 & $2.8 \%$ & & & \\
\hline & & Joseph Hikuta'a & 64 & $1.5 \%$ & & & \\
\hline & & Bendick Tova & 40 & $1.0 \%$ & & & \\
\hline & & Rejected Votes & & $0.0 \%$ & & & \\
\hline & East Guadalcanal Total & & 4,192 & & & & \\
\hline & East Honiara & Douglas Ete & 3,178 & $38.6 \%$ & * & & \\
\hline & & Charles Dausabea & 958 & $11.6 \%$ & & & \\
\hline & & Paul Maenu'u & 913 & $11.1 \%$ & & & \\
\hline & & David Jack Maesua & 912 & $11.1 \%$ & & & \\
\hline & & Simeon Bouro & 678 & $8.2 \%$ & & & \\
\hline & & Geofferry Faisi Samuel & 655 & $8.0 \%$ & & & \\
\hline & & Wycliff Ene & 323 & $3.9 \%$ & & & \\
\hline & & Thompson Guralaua & 246 & $3.0 \%$ & & & \\
\hline & & Catherine Adifaka & 146 & $1.8 \%$ & & & $*$ \\
\hline & & John Nelson Ross & 105 & $1.3 \%$ & & & \\
\hline & & John Laosao & 62 & $0.8 \%$ & & & \\
\hline & & Eddie Misi & 28 & $0.3 \%$ & & & \\
\hline & & Rejected Votes & 25 & $0.3 \%$ & & & \\
\hline
\end{tabular}


General Election Results

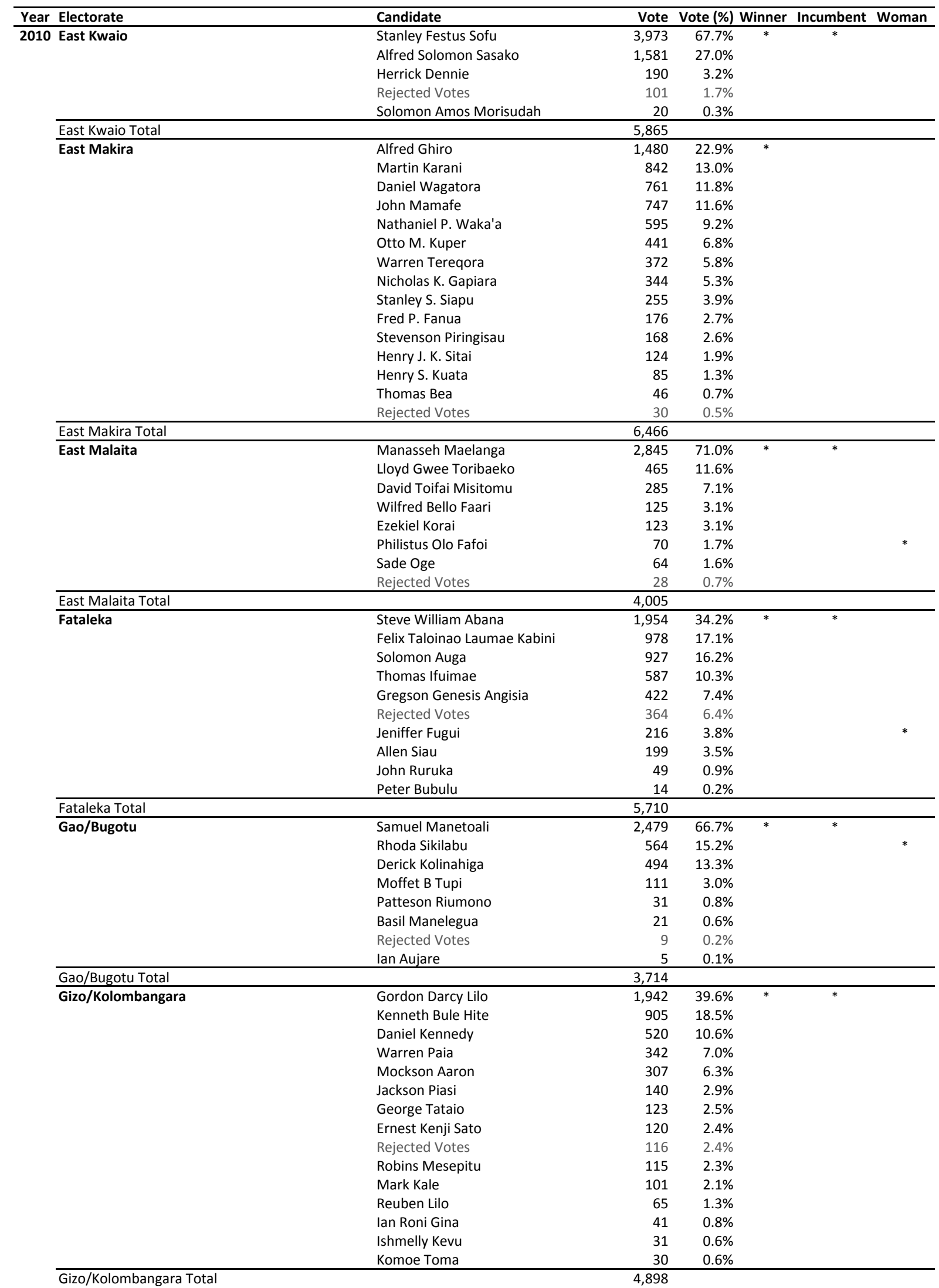


General Election Results

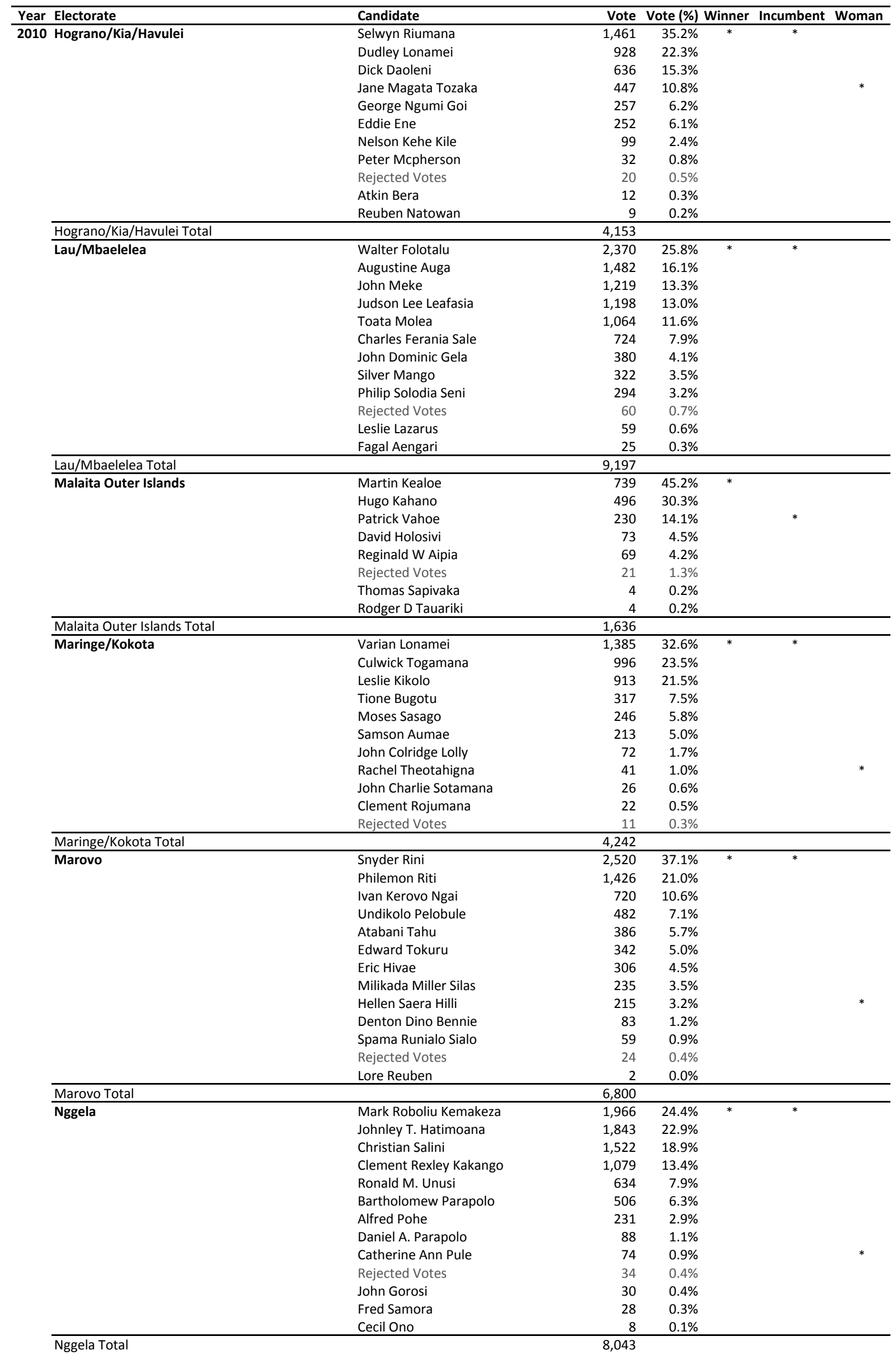


General Election Results

\begin{tabular}{|c|c|c|c|c|c|c|c|}
\hline Year & Electorate & Candidate & Vote & Vote (\%) & Winner & Incumbent & Woman \\
\hline \multirow[t]{21}{*}{2010} & North East Guadalcanal & Derek Sikua & 2,535 & $57.0 \%$ & $*$ & $*$ & \\
\hline & & Alfred Mane Ngelea Lovanitilia & 887 & $19.9 \%$ & & & \\
\hline & & Henry Saea & 317 & $7.1 \%$ & & & \\
\hline & & Ishmael Robert Leuape & 241 & $5.4 \%$ & & & \\
\hline & & Brally Jim Tavalia & 217 & $4.9 \%$ & & & \\
\hline & & Farral Wilfred & 209 & $4.7 \%$ & & & \\
\hline & & Rejected Votes & 43 & $1.0 \%$ & & & \\
\hline & North East Guadalcanal Total & & 4,449 & & & & \\
\hline & \multirow[t]{13}{*}{ North Guadalcanal } & Martin Sopage & 1,489 & $31.2 \%$ & \multirow[t]{13}{*}{$*$} & \multirow[t]{13}{*}{ * } & \multirow{13}{*}{ * } \\
\hline & & Alfred Maeke Junior & 940 & $19.7 \%$ & & & \\
\hline & & Daniel Vedar Buto & 611 & $12.8 \%$ & & & \\
\hline & & Andrew Kuvu & 574 & $12.0 \%$ & & & \\
\hline & & Samson Maneka & 373 & $7.8 \%$ & & & \\
\hline & & Benedict Garimane & 254 & $5.3 \%$ & & & \\
\hline & & Greenta Vienna Tome & 231 & $4.8 \%$ & & & \\
\hline & & John Rossivaena & 154 & $3.2 \%$ & & & \\
\hline & & Harry Barnabas & 64 & $1.3 \%$ & & & \\
\hline & & Rejected Votes & 37 & $0.8 \%$ & & & \\
\hline & & David Qwan & 20 & $0.4 \%$ & & & \\
\hline & & Edmond Sonitavea & 16 & $0.3 \%$ & & & \\
\hline & & Stephen Paeni & 15 & $0.3 \%$ & & & \\
\hline & North Guadalcanal Total & & 4,778 & & & & \\
\hline \multirow{10}{*}{\multicolumn{2}{|c|}{ North Malaita }} & Jimmy Lusibaea & 3,091 & $49.6 \%$ & $*$ & & \\
\hline & & Michael Maeliau & 882 & $14.2 \%$ & & & \\
\hline & & Leslie Leau Kwaiga & 813 & $13.0 \%$ & & & \\
\hline & & Daniel E. Kwanairara & 566 & $9.1 \%$ & & $*$ & \\
\hline & & Mahlon Oduramo Suilifia & 342 & $5.5 \%$ & & & \\
\hline & & Sensie George & 296 & $4.8 \%$ & & & \\
\hline & & Joel Moffat Konofilia & 102 & $1.6 \%$ & & & \\
\hline & & Raymond Aumae & 64 & $1.0 \%$ & & & \\
\hline & & Lawrence Foanaota & 55 & $0.9 \%$ & & & \\
\hline & & Rejected Votes & 19 & $0.3 \%$ & & & \\
\hline & North Malaita Total & & 6,230 & & & & \\
\hline & North New Georgia & Job Dudley Tausinga & 1,419 & $73.9 \%$ & * & * & \\
\hline & & Dewin Alick & 458 & $23.9 \%$ & & & \\
\hline & & Nuatali Tongarutu & 36 & $1.9 \%$ & & & $*$ \\
\hline & & Rejected Votes & 7 & $0.4 \%$ & & & \\
\hline & North New Georgia Total & & 1,920 & & & & \\
\hline & North Vella Lavella & Milner Tozaka & 1,225 & $45.0 \%$ & * & * & \\
\hline & & Pye Robert Kuve & 1,082 & $39.7 \%$ & & & \\
\hline & & Alistair Porebangara Paekera & 292 & $10.7 \%$ & & & \\
\hline & & Maleli Zalao & 64 & $2.3 \%$ & & & \\
\hline & & Casper Dorauvo & 40 & $1.5 \%$ & & & \\
\hline & & Gwen Abana Jitukalo & 12 & $0.4 \%$ & & & $*$ \\
\hline & & Rejected Votes & 9 & $0.3 \%$ & & & \\
\hline & North Vella Lavella Total & & 2,724 & & & & \\
\hline & North West Choiseul & Connelly Sadakabatu & 1,408 & $30.0 \%$ & * & & \\
\hline & & Francis Qalo & 1,151 & $24.5 \%$ & & & \\
\hline & & Ralph Billy Takubala & 1,027 & $21.9 \%$ & & & \\
\hline & & Clement Pikabatu Kengava & 775 & $16.5 \%$ & & * & \\
\hline & & Alpha Kimata & 206 & $4.4 \%$ & & & \\
\hline & & Sylvia Nowak Anderson & 113 & $2.4 \%$ & & & $*$ \\
\hline & & Rejected Votes & 12 & $0.3 \%$ & & & \\
\hline & North West Choiseul Total & & 4,692 & & & & \\
\hline & North West Guadalcanal & Horst Heinz Bodo Dettke & 2,228 & $41.3 \%$ & * & & \\
\hline & & Siriako Usa & 1,382 & $25.6 \%$ & & $*$ & \\
\hline & & Joseph Pali Neilsen & 507 & $9.4 \%$ & & & \\
\hline & & Charles Brown Beu & 456 & $8.5 \%$ & & & \\
\hline & & Solomon Love & 270 & $5.0 \%$ & & & \\
\hline & & Francis Mocho Belande Sade & 176 & $3.3 \%$ & & & \\
\hline & & Hilda Padavera Kii & 117 & $2.2 \%$ & & & * \\
\hline & & Charles Keku Chilivi & 82 & $1.5 \%$ & & & \\
\hline & & Michael Ben Walahoula & 54 & $1.0 \%$ & & & \\
\hline & & Stephen Labu & 48 & $0.9 \%$ & & & \\
\hline & & Rejected Votes & 32 & $0.6 \%$ & & & \\
\hline & & Joseph Solomon Anea & 14 & $0.3 \%$ & & & \\
\hline & & John Quan & 12 & $0.2 \%$ & & & \\
\hline & & Craig Pelu & 9 & $0.2 \%$ & & & \\
\hline & & George Kavoa & 6 & $0.1 \%$ & & & \\
\hline & North West Guadalcanal Total & & 5,393 & & & & \\
\hline & Ranongga/Simbo & Charles Sigoto & 1,485 & $38.4 \%$ & * & & \\
\hline & & Francis Billy Hilly & 1,277 & $33.0 \%$ & & $*$ & \\
\hline & & Belani Tekulu & 697 & $18.0 \%$ & & & \\
\hline & & Elizabeth Tamugula Pearson & 254 & $6.6 \%$ & & & * \\
\hline & & Stephen Suti-Agalo & 118 & $3.1 \%$ & & & \\
\hline & & Rejected Votes & 33 & $0.9 \%$ & & & \\
\hline & Ranongga/Simbo Total & & 3,864 & & & & \\
\hline
\end{tabular}


General Election Results

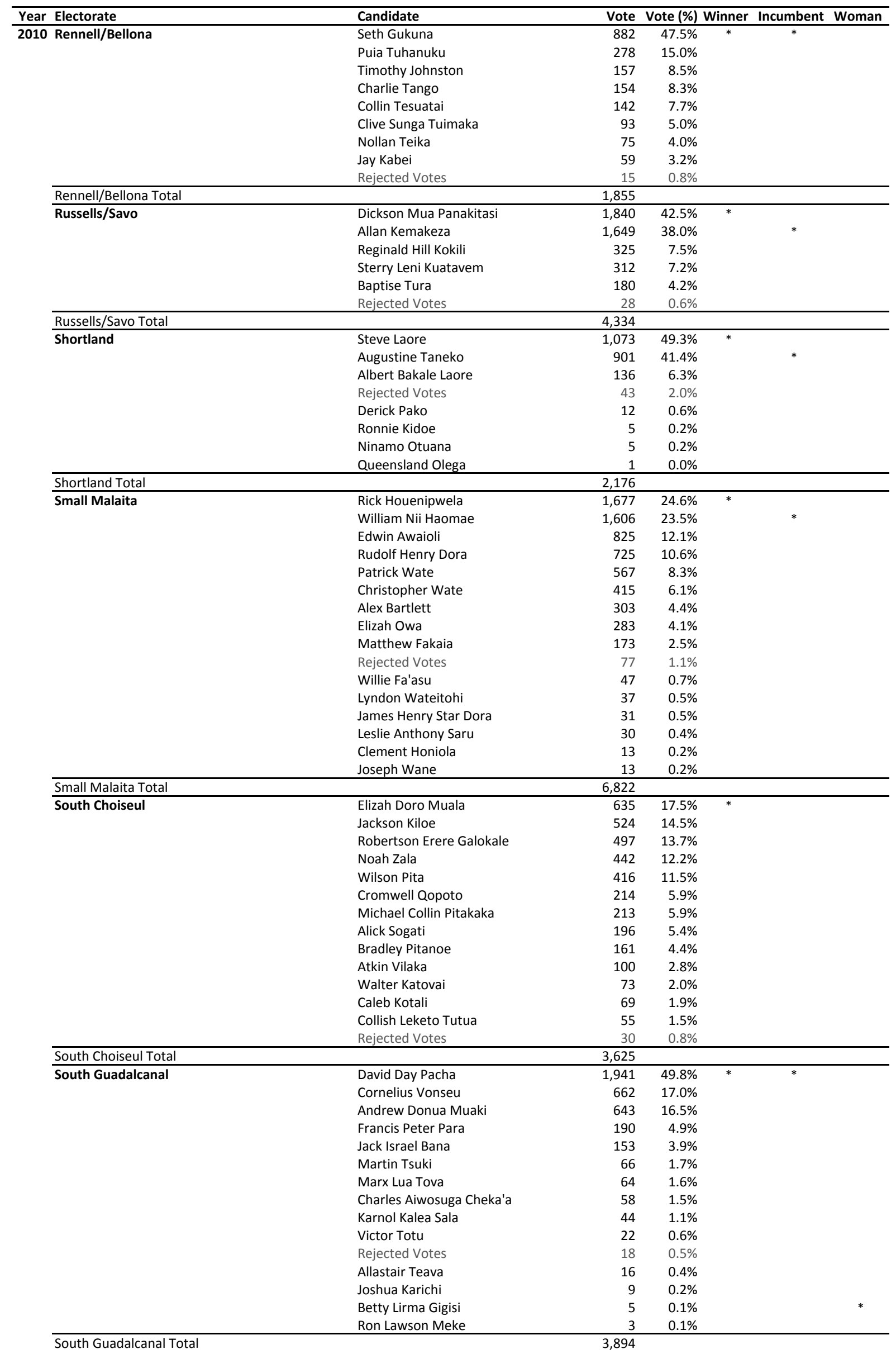


General Election Results

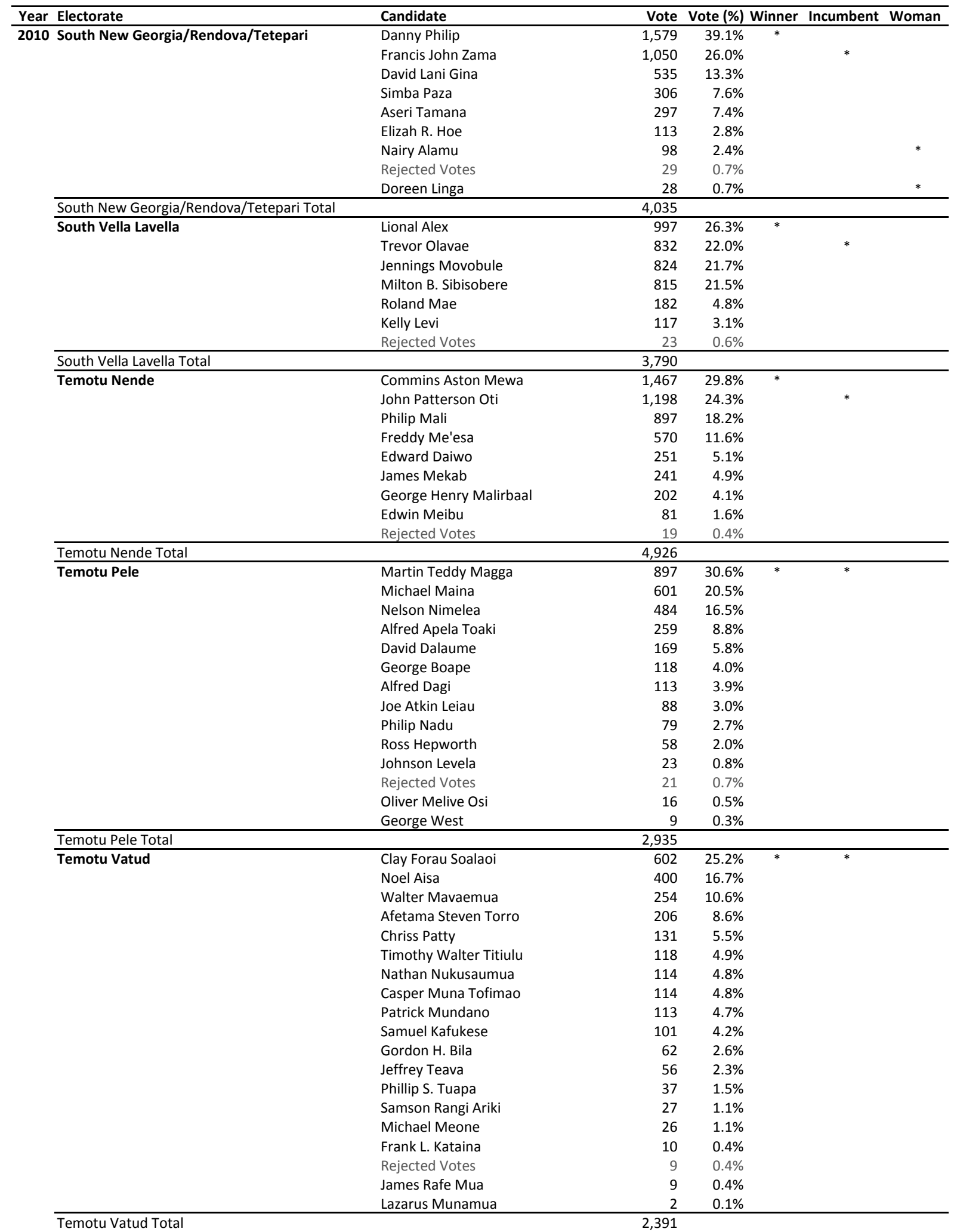


General Election Results

\begin{tabular}{|c|c|c|c|c|c|c|c|}
\hline Year & Electorate & Candidate & Vote & Vote (\%) & Winner & Incumbent & Woman \\
\hline \multirow[t]{15}{*}{2010} & Ulawa/Ugi & James Tora & 641 & $26.0 \%$ & $*$ & $*$ & \\
\hline & & Nathaniel Rahumae Waena & 563 & $22.8 \%$ & & & \\
\hline & & Noel Mamau & 291 & $11.8 \%$ & & & \\
\hline & & Carl Warren Beldon & 214 & $8.7 \%$ & & & \\
\hline & & Augustine Waetara & 182 & $7.4 \%$ & & & \\
\hline & & Peter Titiulu & 116 & $4.7 \%$ & & & \\
\hline & & Henry Marau & 94 & $3.8 \%$ & & & \\
\hline & & Ashley Rohorua Riwenimae & 89 & $3.6 \%$ & & & \\
\hline & & Michael Ramsey Poki & 80 & $3.2 \%$ & & & \\
\hline & & Wilfred Robertson Natei & 66 & $2.7 \%$ & & & \\
\hline & & Meffrey Awao & 51 & $2.1 \%$ & & & \\
\hline & & Raphael Oli & 39 & $1.6 \%$ & & & \\
\hline & & Fox Cornes Sumaheniau & 26 & $1.1 \%$ & & & \\
\hline & & Rejected Votes & 7 & $0.3 \%$ & & & \\
\hline & & Joseph Harry Maka'a & 5 & $0.2 \%$ & & & \\
\hline & Ulawa/Ugi Total & & 2,464 & & & & \\
\hline \multirow{11}{*}{\multicolumn{2}{|c|}{ West Are' Are }} & John Maneniaru & 1,281 & $32.2 \%$ & * & & \\
\hline & & Severino Nuaiasi & 1,178 & $29.6 \%$ & & * & \\
\hline & & Martin Tome Haikau & 406 & $10.2 \%$ & & & \\
\hline & & Campion Ohasio & 259 & $6.5 \%$ & & & \\
\hline & & Andrew Nori & 190 & $4.8 \%$ & & & \\
\hline & & Samson Maeniuta Rihuoha & 175 & $4.4 \%$ & & & \\
\hline & & Peter Hauia & 161 & $4.1 \%$ & & & \\
\hline & & Paul Rasuhiraro Opaka & 146 & $3.7 \%$ & & & \\
\hline & & Slayde Waiwaki Ehakeni & 130 & $3.3 \%$ & & & \\
\hline & & Joe Timothy Ariaria & 34 & $0.9 \%$ & & & \\
\hline & & Rejected Votes & 15 & $0.4 \%$ & & & \\
\hline & West Are' Are Total & & 3,975 & & & & \\
\hline \multirow{12}{*}{\multicolumn{2}{|c|}{ West Guadalcanal }} & Moses Garu & 1,006 & $23.2 \%$ & * & & \\
\hline & & Pascal Belamataga & 840 & $19.3 \%$ & & & \\
\hline & & Anthony Kamu Veke & 778 & $17.9 \%$ & & & \\
\hline & & Peter S. Haeo & 466 & $10.7 \%$ & & & \\
\hline & & David Rosalio & 451 & $10.4 \%$ & & & \\
\hline & & Samson Teteha & 245 & $5.6 \%$ & & & \\
\hline & & Obadiah Gadi & 201 & $4.6 \%$ & & & \\
\hline & & Joshua Bulolo & 165 & $3.8 \%$ & & & \\
\hline & & Edme Ziokera & 101 & $2.3 \%$ & & & $*$ \\
\hline & & Rejected Votes & 70 & $1.6 \%$ & & & \\
\hline & & Silas Devine Gift Lauvisu & 20 & $0.5 \%$ & & & \\
\hline & & George W. Mangale & 1 & $0.0 \%$ & & & \\
\hline & West Guadalcanal Total & & 4,344 & & & & \\
\hline \multirow{7}{*}{\multicolumn{2}{|c|}{ West Honiara }} & Namson Tran & 4,499 & $56.6 \%$ & * & & \\
\hline & & Isaac Inoke Tosika & 1,552 & $19.5 \%$ & & $*$ & \\
\hline & & Alfred Soaki & 892 & $11.2 \%$ & & & \\
\hline & & Catherine Sheardown Atanikakia & 516 & $6.5 \%$ & & & $*$ \\
\hline & & Andrew Mua & 299 & $3.8 \%$ & & & \\
\hline & & Toxi Polyn & 103 & $1.3 \%$ & & & \\
\hline & & Rejected Votes & 90 & $1.1 \%$ & & & \\
\hline & West Honiara Total & & 7,951 & & & & \\
\hline \multirow{14}{*}{\multicolumn{2}{|c|}{ West Kwaio }} & Peter Tom & 1,550 & $34.8 \%$ & * & * & \\
\hline & & Augustine Lafo & 790 & $17.7 \%$ & & & \\
\hline & & Jack Ofoata & 611 & $13.7 \%$ & & & \\
\hline & & Mathias Olofia & 387 & $8.7 \%$ & & & \\
\hline & & Fred Sisifiu & 303 & $6.8 \%$ & & & \\
\hline & & Harry Kwalafunu & 253 & $5.7 \%$ & & & \\
\hline & & Robert Wales Feraltelia & 126 & $2.8 \%$ & & & \\
\hline & & Alfred Afeau & 125 & $2.8 \%$ & & & \\
\hline & & Charles Karaori & 118 & $2.7 \%$ & & & \\
\hline & & Fred Saega & 59 & $1.3 \%$ & & & \\
\hline & & Tony Uania & 57 & $1.3 \%$ & & & \\
\hline & & Henry Dada & 40 & $0.9 \%$ & & & \\
\hline & & Rejected Votes & 18 & $0.4 \%$ & & & \\
\hline & & Anderson K. Raenaitoro & 14 & $0.3 \%$ & & & \\
\hline
\end{tabular}


General Election Results

\begin{tabular}{|c|c|c|c|c|c|c|c|}
\hline Year & Electorate & Candidate & Vote & Vote (\%) & Winner & Incumbent & Woman \\
\hline \multirow[t]{50}{*}{2010} & West Kwara'ae & Sam Shemuel Iduri & 1,451 & $18.4 \%$ & $*$ & $*$ & \\
\hline & & Martin Saefafia & 1,015 & $12.8 \%$ & & & \\
\hline & & Jack Kaota & 961 & $12.2 \%$ & & & \\
\hline & & Sam Alasia & 827 & $10.5 \%$ & & & \\
\hline & & Casper Kosute'e Dausabea & 789 & $10.0 \%$ & & & \\
\hline & & Allan Tori Tomu & 631 & $8.0 \%$ & & & \\
\hline & & Martin Aebata & 614 & $7.8 \%$ & & & \\
\hline & & Paul Kukute Daokalia & 461 & $5.8 \%$ & & & \\
\hline & & Martin Fini & 337 & $4.3 \%$ & & & \\
\hline & & Simon Mannie & 251 & $3.2 \%$ & & & \\
\hline & & Augustine Faliomea Maelifaka & 207 & $2.6 \%$ & & & \\
\hline & & Erickson Otia & 64 & $0.8 \%$ & & & \\
\hline & & Fred Maniau & 63 & $0.8 \%$ & & & \\
\hline & & John Alfred Tuasulia & 63 & $0.8 \%$ & & & \\
\hline & & Henry Tagini Anita & 58 & $0.7 \%$ & & & \\
\hline & & Rejected Votes & 40 & $0.5 \%$ & & & \\
\hline & & Robert Madeo & 35 & $0.4 \%$ & & & \\
\hline & & Jared Daudau Tagini & 29 & $0.4 \%$ & & & \\
\hline & & Leslie Osimae & 8 & $0.1 \%$ & & & \\
\hline & West Kwara'ae Total & & 7,904 & & & & \\
\hline & West Makira & Dick Ha'amori & 871 & $18.5 \%$ & $*$ & & \\
\hline & & Jackson Sunaone & 788 & $16.8 \%$ & & & \\
\hline & & Paul Marita & 518 & $11.0 \%$ & & & \\
\hline & & Japhet Waipora & 377 & $8.0 \%$ & & $*$ & \\
\hline & & James Morea & 331 & $7.0 \%$ & & & \\
\hline & & Jimmy Hanson Riunga & 327 & $7.0 \%$ & & & \\
\hline & & Daniel Dautaha & 310 & $6.6 \%$ & & & \\
\hline & & Golden Kiloko & 271 & $5.8 \%$ & & & \\
\hline & & Nelson Nausi & 227 & $4.8 \%$ & & & \\
\hline & & Peter Trena Raraha'abura & 160 & $3.4 \%$ & & & \\
\hline & & Edmond Dangi & 134 & $2.9 \%$ & & & \\
\hline & & Alick Dangi & 121 & $2.6 \%$ & & & \\
\hline & & Richard Taro & 120 & $2.6 \%$ & & & \\
\hline & & Jackton Raeri & 92 & $2.0 \%$ & & & \\
\hline & & John Mepuke Ta'aru & 36 & $0.8 \%$ & & & \\
\hline & & Rejected Votes & 18 & $0.4 \%$ & & & \\
\hline & West Makira Total & & 4,701 & & & & \\
\hline & West New Georgia/Vona Vona & Silas Kerry Vaqara Tausinga & 1,487 & $27.5 \%$ & * & & \\
\hline & & Peter James Boyers & 1,327 & $24.6 \%$ & & $*$ & \\
\hline & & Aquila Talasasa & 680 & $12.6 \%$ & & & \\
\hline & & Gloria Sibisobere & 594 & $11.0 \%$ & & & $*$ \\
\hline & & Billy Veo & 508 & $9.4 \%$ & & & \\
\hline & & Selina Boso & 211 & $3.9 \%$ & & & $*$ \\
\hline & & Nelson Boso & 186 & $3.4 \%$ & & & \\
\hline & & Joseph Douglas & 159 & $2.9 \%$ & & & \\
\hline & & Patt R. Loe & 96 & $1.8 \%$ & & & \\
\hline & & Milton Talasasa & 84 & $1.6 \%$ & & & \\
\hline & & Rejected Votes & 37 & $0.7 \%$ & & & \\
\hline & & Robertson Bato & 24 & $0.4 \%$ & & & \\
\hline & & Wilson Gina & 7 & $0.1 \%$ & & & \\
\hline
\end{tabular}


General Election Results

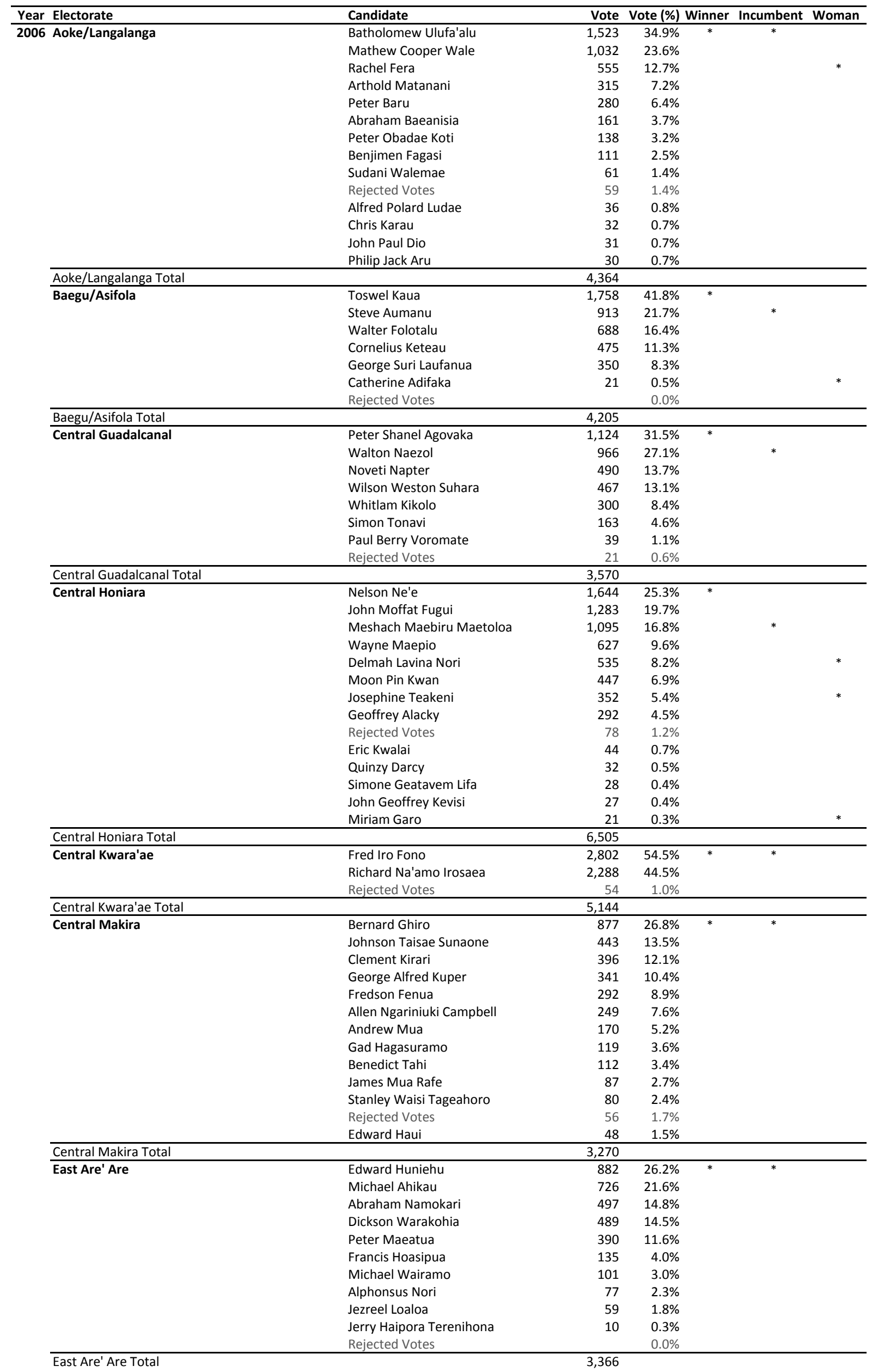


General Election Results

\begin{tabular}{|c|c|c|c|c|c|c|c|}
\hline Year & Electorate & Candidate & Vote & Vote (\%) & Winner & Incumbent & Woman \\
\hline \multirow[t]{10}{*}{2006} & East Central Guadalcanal & Nollen C. Leni & 984 & $23.2 \%$ & \multirow[t]{10}{*}{$*$} & \multirow[t]{10}{*}{$*$} & \multirow{10}{*}{$*$} \\
\hline & & Gordon Tapalia & 799 & $18.8 \%$ & & & \\
\hline & & Hilda Thugea Kari & 655 & $15.4 \%$ & & & \\
\hline & & John Gela & 577 & $13.6 \%$ & & & \\
\hline & & Benjamin Savino & 377 & $8.9 \%$ & & & \\
\hline & & Nathaniel Mara & 294 & $6.9 \%$ & & & \\
\hline & & Jamie Lency Vokia & 269 & $6.3 \%$ & & & \\
\hline & & John Selwyn Besa'A & 261 & $6.1 \%$ & & & \\
\hline & & Johnson Meshach Villia & 30 & $0.7 \%$ & & & \\
\hline & & Rejected Votes & & $0.0 \%$ & & & \\
\hline & East Central Guadalcanal Total & & 4,246 & & & & \\
\hline \multirow{6}{*}{\multicolumn{2}{|c|}{ East Choiseul }} & Mannaseh Sogavare & 854 & $35.7 \%$ & \multirow[t]{6}{*}{ * } & * & \\
\hline & & Francis Qalokamake & 646 & $27.0 \%$ & & & \\
\hline & & Gordon Volaka & 371 & $15.5 \%$ & & & \\
\hline & & Moses Kurebose Biliki & 355 & $14.8 \%$ & & & \\
\hline & & Billy Takubala & 136 & $5.7 \%$ & & & \\
\hline & & Rejected Votes & 32 & $1.3 \%$ & & & \\
\hline & East Choiseul Total & & 2,394 & & & & \\
\hline & East Guadalcanal & Johnson Koli & 1,172 & $34.6 \%$ & * & $*$ & \\
\hline & & Fred Laku & 571 & $16.9 \%$ & & & \\
\hline & & Bendick Tova & 568 & $16.8 \%$ & & & \\
\hline & & Joseph Hikuta'a & 493 & $14.6 \%$ & & & \\
\hline & & John Marahare & 280 & $8.3 \%$ & & & \\
\hline & & Shaniella Talasifera & 153 & $4.5 \%$ & & & $*$ \\
\hline & & Rejected Votes & 150 & $4.4 \%$ & & & \\
\hline & East Guadalcanal Total & & 3,387 & & & & \\
\hline & East Honiara & Charles Dausabea & 1,892 & $23.0 \%$ & * & & \\
\hline & & Simeon Bouro & 1,232 & $15.0 \%$ & & $*$ & \\
\hline & & Edward Jacob Ronia & 1,110 & $13.5 \%$ & & & \\
\hline & & George Mamimu & 1,026 & $12.5 \%$ & & & \\
\hline & & Jack Donga & 514 & $6.2 \%$ & & & \\
\hline & & Dominic Tata & 466 & $5.7 \%$ & & & \\
\hline & & Ronald Ila Fugui & 443 & $5.4 \%$ & & & \\
\hline & & Samuel Maesatana & 210 & $2.5 \%$ & & & \\
\hline & & Dickson Waimora & 204 & $2.5 \%$ & & & \\
\hline & & Wilson B. Karamui & 202 & $2.5 \%$ & & & \\
\hline & & Robert Wales Feraltelia & 176 & $2.1 \%$ & & & \\
\hline & & Rejected Votes & 162 & $2.0 \%$ & & & \\
\hline & & Francis Ramoifuila & 151 & $1.8 \%$ & & & \\
\hline & & John Maetia Kaliuae & 90 & $1.1 \%$ & & & \\
\hline & & Paul Kakai & 71 & $0.9 \%$ & & & \\
\hline & & Gabriel Taloikwai & 68 & $0.8 \%$ & & & \\
\hline & & Peter Usi & 63 & $0.8 \%$ & & & \\
\hline & & Fred Binta Talafunu & 47 & $0.6 \%$ & & & \\
\hline & & Elson Maetia Hilly & 46 & $0.6 \%$ & & & \\
\hline & & Saxon Talo & 42 & $0.5 \%$ & & & \\
\hline & & Edwin Sitori Nanau & 24 & $0.3 \%$ & & & \\
\hline & East Honiara Total & & 8,239 & & & & \\
\hline & East Kwaio & Stanley Festus Sofu & 1,557 & $33.7 \%$ & * & & \\
\hline & & Senda Fifi & 849 & $18.4 \%$ & & & \\
\hline & & Billy Abae & 701 & $15.2 \%$ & & & \\
\hline & & Alfred Solomon Sasako & 652 & $14.1 \%$ & & $*$ & \\
\hline & & Delson Wane Safa'a & 475 & $10.3 \%$ & & & \\
\hline & & Henry Faasifoabae & 226 & $4.9 \%$ & & & \\
\hline & & Nelson Richard Isika & 163 & $3.5 \%$ & & & \\
\hline & & Rejected Votes & & $0.0 \%$ & & & \\
\hline & East Kwaio Total & & 4,623 & & & & \\
\hline & East Makira & David Sitai & 1,240 & $25.3 \%$ & * & * & \\
\hline & & Alfred Ghiro & 1,132 & $23.1 \%$ & & & \\
\hline & & Fred P. Fanua & 579 & $11.8 \%$ & & & \\
\hline & & Doreen Ysabel Kuper & 567 & $11.6 \%$ & & & $*$ \\
\hline & & George Kuata & 488 & $10.0 \%$ & & & \\
\hline & & Warren Tereqora & 324 & $6.6 \%$ & & & \\
\hline & & Daniel Dannah Nahusu & 301 & $6.2 \%$ & & & \\
\hline & & Stanley S. Siapu & 200 & $4.1 \%$ & & & \\
\hline & & Francis Tagua & 62 & $1.3 \%$ & & & \\
\hline & & Rejected Votes & & $0.0 \%$ & & & \\
\hline & East Makira Total & & 4,893 & & & & \\
\hline & East Malaita & Joses Wawari Sanga & 1,601 & $45.3 \%$ & * & $*$ & \\
\hline & & Afu Lia Billy & 738 & $20.9 \%$ & & & $*$ \\
\hline & & Alfred Maetia & 583 & $16.5 \%$ & & & \\
\hline & & Chris Maebiru & 254 & $7.2 \%$ & & & \\
\hline & & Nation Sia Saelea & 178 & $5.0 \%$ & & & \\
\hline & & Robert Nathan Mautai & 119 & $3.4 \%$ & & & \\
\hline & & Rejected Votes & 57 & $1.6 \%$ & & & \\
\hline & & Eddie Misitee Leanafaka & 6 & $0.2 \%$ & & & \\
\hline & East Malaita Total & & 3,536 & & & & \\
\hline
\end{tabular}


General Election Results

\begin{tabular}{|c|c|c|c|c|c|c|c|}
\hline Year & Electorate & Candidate & Vote & Vote (\%) & Winner & Incumbent & Woman \\
\hline \multirow[t]{42}{*}{2006} & \multirow[t]{16}{*}{ Fataleka } & Steve William Abana & 1,056 & $26.0 \%$ & $*$ & \multirow[t]{16}{*}{ 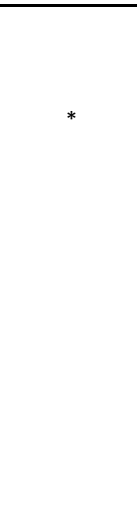 } & \multirow{16}{*}{$\begin{array}{l}* \\
*\end{array}$} \\
\hline & & Felix Taloinao Laumae Kabini & 989 & $24.4 \%$ & & & \\
\hline & & Gabriel Kaula & 684 & $16.9 \%$ & & & \\
\hline & & Casper Cassidy Luiramo & 574 & $14.2 \%$ & & & \\
\hline & & Andy Tony Tosasai & 143 & $3.5 \%$ & & & \\
\hline & & Wilson Maemae & 143 & $3.5 \%$ & & & \\
\hline & & David Siau & 127 & $3.1 \%$ & & & \\
\hline & & George Paul Fia & 122 & $3.0 \%$ & & & \\
\hline & & Hendry Ra'aga & 46 & $1.1 \%$ & & & \\
\hline & & Rejected Votes & 41 & $1.0 \%$ & & & \\
\hline & & Alice Kakabu Baekalia & 37 & $0.9 \%$ & & & \\
\hline & & Catherine Leta & 34 & $0.8 \%$ & & & \\
\hline & & Samuel Ifuna'au & 28 & $0.7 \%$ & & & \\
\hline & & Patrick Uma & 17 & $0.4 \%$ & & & \\
\hline & & George Abana Sanga & 13 & $0.3 \%$ & & & \\
\hline & & Billy Dauma & 1 & $0.0 \%$ & & & \\
\hline & Fataleka Total & & 4,055 & & & & \\
\hline & \multirow{16}{*}{ Gao/Bugotu } & Samuel Manetoali & 978 & $31.6 \%$ & * & \multirow{16}{*}{ * } & \\
\hline & & Basil Manelegua & 306 & $9.9 \%$ & & & \\
\hline & & Nathaniel Supa & 301 & $9.7 \%$ & & & \\
\hline & & Warren B Sikilabu & 268 & $8.7 \%$ & & & \\
\hline & & Edmund Bourne Gagahe & 234 & $7.6 \%$ & & & \\
\hline & & Trasel Gilbert & 202 & $6.5 \%$ & & & \\
\hline & & Eric Notere & 178 & $5.8 \%$ & & & \\
\hline & & Nicholas Lolita & 171 & $5.5 \%$ & & & \\
\hline & & Doris Bava & 97 & $3.1 \%$ & & & $*$ \\
\hline & & John Patteson Bako & 97 & $3.1 \%$ & & & \\
\hline & & William Manepolo & 74 & $2.4 \%$ & & & \\
\hline & & Ian Aujare & 54 & $1.7 \%$ & & & \\
\hline & & Rejected Votes & 47 & $1.5 \%$ & & & \\
\hline & & Nathaniel Gudfraede & 42 & $1.4 \%$ & & & \\
\hline & & John Salano & 34 & $1.1 \%$ & & & \\
\hline & & Ambrose H Bugotu & 11 & $0.4 \%$ & & & \\
\hline & Gao/Bugotu Total & & 3,094 & & & & \\
\hline & \multirow[t]{7}{*}{ Gizo/Kolombangara } & Gordon Darcy Lilo & 1,810 & $45.7 \%$ & * & \multirow[t]{7}{*}{ * } & \\
\hline & & Chachabule Amoi & 726 & $18.3 \%$ & & & \\
\hline & & Stephen Suti-Agalo & 519 & $13.1 \%$ & & & \\
\hline & & Jackson Piasi & 408 & $10.3 \%$ & & & \\
\hline & & Vainga Taniera Tion & 323 & $8.2 \%$ & & & \\
\hline & & Demetrius Tarabangara Piziki & 143 & $3.6 \%$ & & & \\
\hline & & Rejected Votes & 33 & $0.8 \%$ & & & \\
\hline & Gizo/Kolombangara Total & & 3,962 & & & & \\
\hline \multirow[t]{27}{*}{2006} & Hograno/Kia/Havulei & Selwyn Riumana & 937 & $27.4 \%$ & * & \multirow{10}{*}{$*$} & \\
\hline & & Dick Daoleni & 541 & $15.8 \%$ & & & \\
\hline & & Jane Magata Tozaka & 507 & $14.8 \%$ & & & $*$ \\
\hline & & Nelson Kehe Kile & 449 & $13.1 \%$ & & & \\
\hline & & Luke Layman Eta & 298 & $8.7 \%$ & & & \\
\hline & & Johnson Leamana & 237 & $6.9 \%$ & & & \\
\hline & & Cornelius Rathamana & 199 & $5.8 \%$ & & & \\
\hline & & Jason B Leguhavi & 177 & $5.2 \%$ & & & \\
\hline & & Rejected Votes & 37 & $1.1 \%$ & & & \\
\hline & & Charles Misari Ravinago & 36 & $1.1 \%$ & & & \\
\hline & Hograno/Kia/Havulei Total & & 3,418 & & & & \\
\hline & Lau/Mbaelelea & Bentley Samuel Rogosomani & 1,546 & $22.2 \%$ & * & & \\
\hline & & Judson Lee Leafasia & 1,246 & $17.9 \%$ & & & \\
\hline & & Francis Maaka & 1,072 & $15.4 \%$ & & & \\
\hline & & Paul Maenu'u & 1,045 & $15.0 \%$ & & * & \\
\hline & & Charles Ferania Sale & 762 & $10.9 \%$ & & & \\
\hline & & John Beui Lamani & 304 & $4.4 \%$ & & & \\
\hline & & Aaron Rubin Olofia & 290 & $4.2 \%$ & & & \\
\hline & & Peter Satu & 177 & $2.5 \%$ & & & \\
\hline & & Toata Molea & 150 & $2.2 \%$ & & & \\
\hline & & Philip Oeta & 138 & $2.0 \%$ & & & \\
\hline & & Hedley Aluta Toata & 77 & $1.1 \%$ & & & \\
\hline & & Duddley Wate & 69 & $1.0 \%$ & & & \\
\hline & & Frederick Taloimatakwa & 44 & $0.6 \%$ & & & \\
\hline & & William R. Garaema & 32 & $0.5 \%$ & & & \\
\hline & & Luke Tome & 10 & $0.1 \%$ & & & \\
\hline & & Rejected Votes & & $0.0 \%$ & & & \\
\hline
\end{tabular}


General Election Results

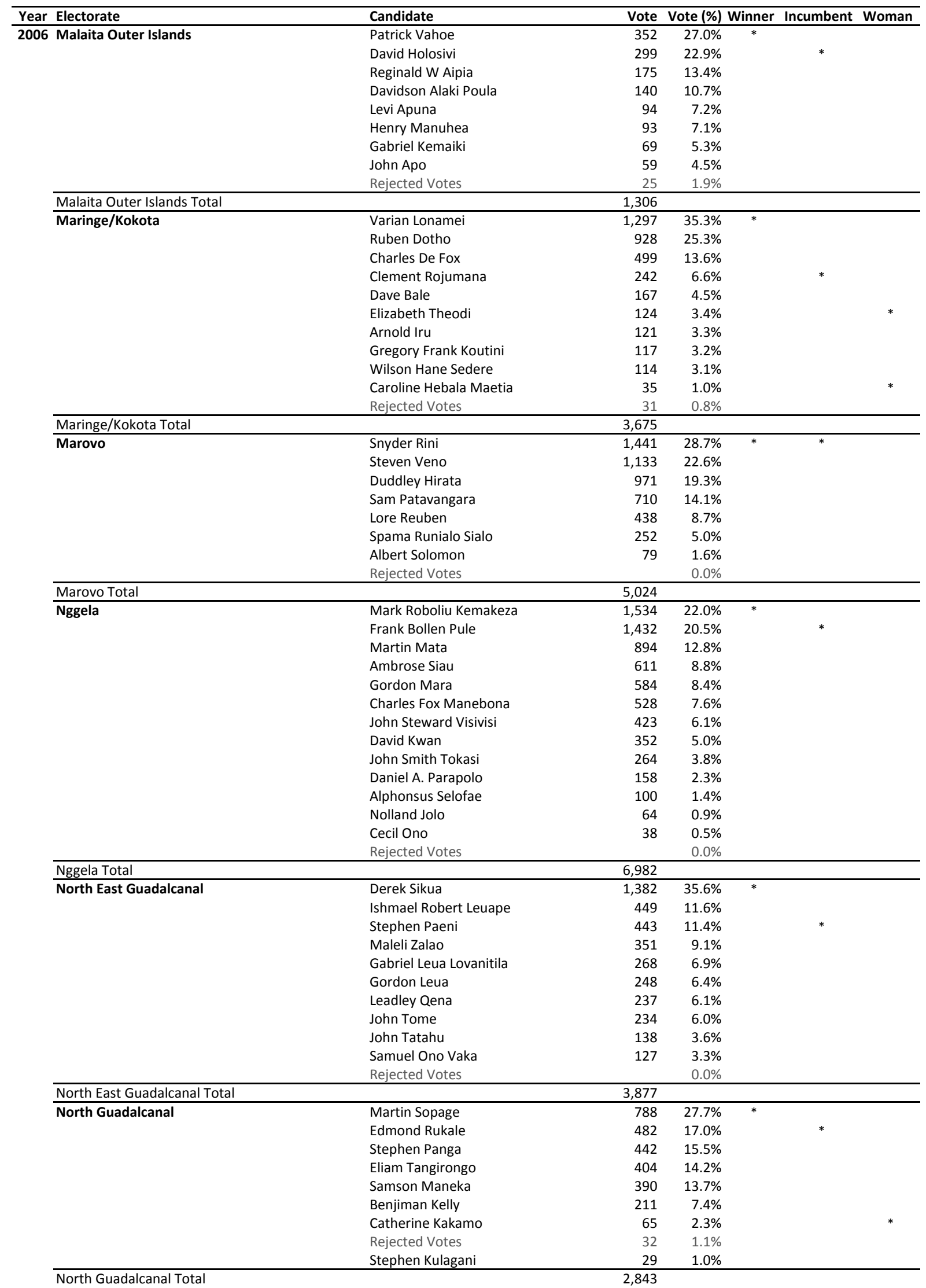


General Election Results

\begin{tabular}{|c|c|c|c|c|c|c|c|}
\hline $\begin{array}{l}\text { Year E } \\
2006 \quad 1\end{array}$ & \multirow{2}{*}{$\begin{array}{l}\text { Electorate } \\
\text { North Malaita }\end{array}$} & \multirow{2}{*}{$\begin{array}{l}\text { Candidate } \\
\text { Daniel E Kwanairara }\end{array}$} & \multirow{2}{*}{$\begin{array}{r}\text { Vote } \\
2,292\end{array}$} & \multirow{2}{*}{$\begin{array}{r}\text { Vote (\%) } \\
41.6 \%\end{array}$} & \multirow{2}{*}{$\frac{\text { Winner }}{*}$} & \multirow{2}{*}{$\frac{\text { Incumbent }}{*}$} & Woman \\
\hline \multirow[t]{69}{*}{2006} & & & & & & & \\
\hline & & Michael Maeliau & 1,487 & $27.0 \%$ & & & \\
\hline & & Michael Iro & 478 & $8.7 \%$ & & & \\
\hline & & Ronnie Faiga & 474 & $8.6 \%$ & & & \\
\hline & & Jemuel William Liobana & 413 & $7.5 \%$ & & & \\
\hline & & Benjamin Laefanaomea Riiga & 221 & $4.0 \%$ & & & \\
\hline & & Starling Daefa & 118 & $2.1 \%$ & & & \\
\hline & & George Walenenea & 22 & $0.4 \%$ & & & \\
\hline & & Moffat Stephen Ganisua & 9 & $0.2 \%$ & & & \\
\hline & & Rejected Votes & & $0.0 \%$ & & & \\
\hline & North Malaita Total & & 5,514 & & & & \\
\hline & North New Georgia & Job Dudley Tausinga & & $100.0 \%$ & * & * & \\
\hline & North New Georgia Total & & & & & & \\
\hline & North Vella Lavella & Milner Tozaka & 573 & $26.4 \%$ & * & & \\
\hline & & Danny Bula & 571 & $26.3 \%$ & & $*$ & \\
\hline & & lodine Panasasa & 285 & $13.1 \%$ & & & \\
\hline & & Pye Robert Kuve & 262 & $12.1 \%$ & & & \\
\hline & & Lepesi Paul Jama & 235 & $10.8 \%$ & & & \\
\hline & & Billy Maelagi & 217 & $10.0 \%$ & & & \\
\hline & & Rejected Votes & 28 & $1.3 \%$ & & & \\
\hline & North Vella Lavella Total & & 2,171 & & & & \\
\hline & North West Choiseul & Clement Pikabatu Kengava & 1,271 & $31.4 \%$ & * & * & \\
\hline & & Jerold Simmy Vazarabatu & 722 & $17.8 \%$ & & & \\
\hline & & John Ridd Kure & 611 & $15.1 \%$ & & & \\
\hline & & Alpha Kimata & 571 & $14.1 \%$ & & & \\
\hline & & Luke Pitakoe & 470 & $11.6 \%$ & & & \\
\hline & & William Pita Kutinikolo & 241 & $5.9 \%$ & & & \\
\hline & & Gabby Taniveke & 117 & $2.9 \%$ & & & \\
\hline & & Rejected Votes & 51 & $1.3 \%$ & & & \\
\hline & North West Choiseul Total & & 4,054 & & & & \\
\hline & North West Guadalcanal & Siriako Usa & 1,028 & $29.1 \%$ & * & * & \\
\hline & & Joseph Pali Neilsen & 803 & $22.7 \%$ & & & \\
\hline & & David Sali & 590 & $16.7 \%$ & & & \\
\hline & & Richard Selwyn Baokosu & 456 & $12.9 \%$ & & & \\
\hline & & Doreen Maeke & 181 & $5.1 \%$ & & & $*$ \\
\hline & & Japhet Voselau & 175 & $5.0 \%$ & & & \\
\hline & & Francis Orodani & 164 & $4.6 \%$ & & & \\
\hline & & Kanuto Kobi & 81 & $2.3 \%$ & & & \\
\hline & & Bernadette Tadakusu & 44 & $1.2 \%$ & & & $*$ \\
\hline & & Gordon Billy Gatu & 12 & $0.3 \%$ & & & \\
\hline & & Rejected Votes & & $0.0 \%$ & & & \\
\hline & North West Guadalcanal Total & & 3,534 & & & & \\
\hline & Ranongga/Simbo & Francis Billy Hilly & 1,098 & $33.0 \%$ & * & * & \\
\hline & & Jimmy Sendersley & 1,024 & $30.8 \%$ & & & \\
\hline & & Reuben Lilo & 738 & $22.2 \%$ & & & \\
\hline & & Jay Hong & 288 & $8.7 \%$ & & & \\
\hline & & Charles Kelly & 94 & $2.8 \%$ & & & \\
\hline & & Rejected Votes & 45 & $1.4 \%$ & & & \\
\hline & & Pelopi Tada Lomae & 42 & $1.3 \%$ & & & \\
\hline & Ranongga/Simbo Total & & 3,329 & & & & \\
\hline & Rennell/Bellona & Seth Gukuna & 431 & $25.0 \%$ & * & & \\
\hline & & Charlie Tango & 307 & $17.8 \%$ & & & \\
\hline & & Joses Taungenga Tuhanuku & 262 & $15.2 \%$ & & $*$ & \\
\hline & & Lence R. Tagosia & 248 & $14.4 \%$ & & & \\
\hline & & Chard-Richard Maui Hatingongo & 163 & $9.4 \%$ & & & \\
\hline & & Saueha Joses Tahua & 145 & $8.4 \%$ & & & \\
\hline & & Ajilon J. Nasiu & 100 & $5.8 \%$ & & & \\
\hline & & T. Tuhenua & 55 & $3.2 \%$ & & & \\
\hline & & Rejected Votes & 15 & $0.9 \%$ & & & \\
\hline & Rennell/Bellona Total & & 1,726 & & & & \\
\hline & Russells/Savo & Allan Kemakeza & 1,310 & $30.0 \%$ & * & * & \\
\hline & & Reginald Hill Kokili & 1,055 & $24.1 \%$ & & & \\
\hline & & Stanley S Manetiva & 806 & $18.4 \%$ & & & \\
\hline & & Christopher Narasia & 359 & $8.2 \%$ & & & \\
\hline & & Tony Kagovai & 313 & $7.2 \%$ & & & \\
\hline & & Peter Damien Tura & 288 & $6.6 \%$ & & & \\
\hline & & Leotina Kikitu & 177 & $4.0 \%$ & & & $*$ \\
\hline & & Nivardo Tuanikebu & 64 & $1.5 \%$ & & & \\
\hline & & Rejected Votes & & $0.0 \%$ & & & \\
\hline
\end{tabular}


General Election Results

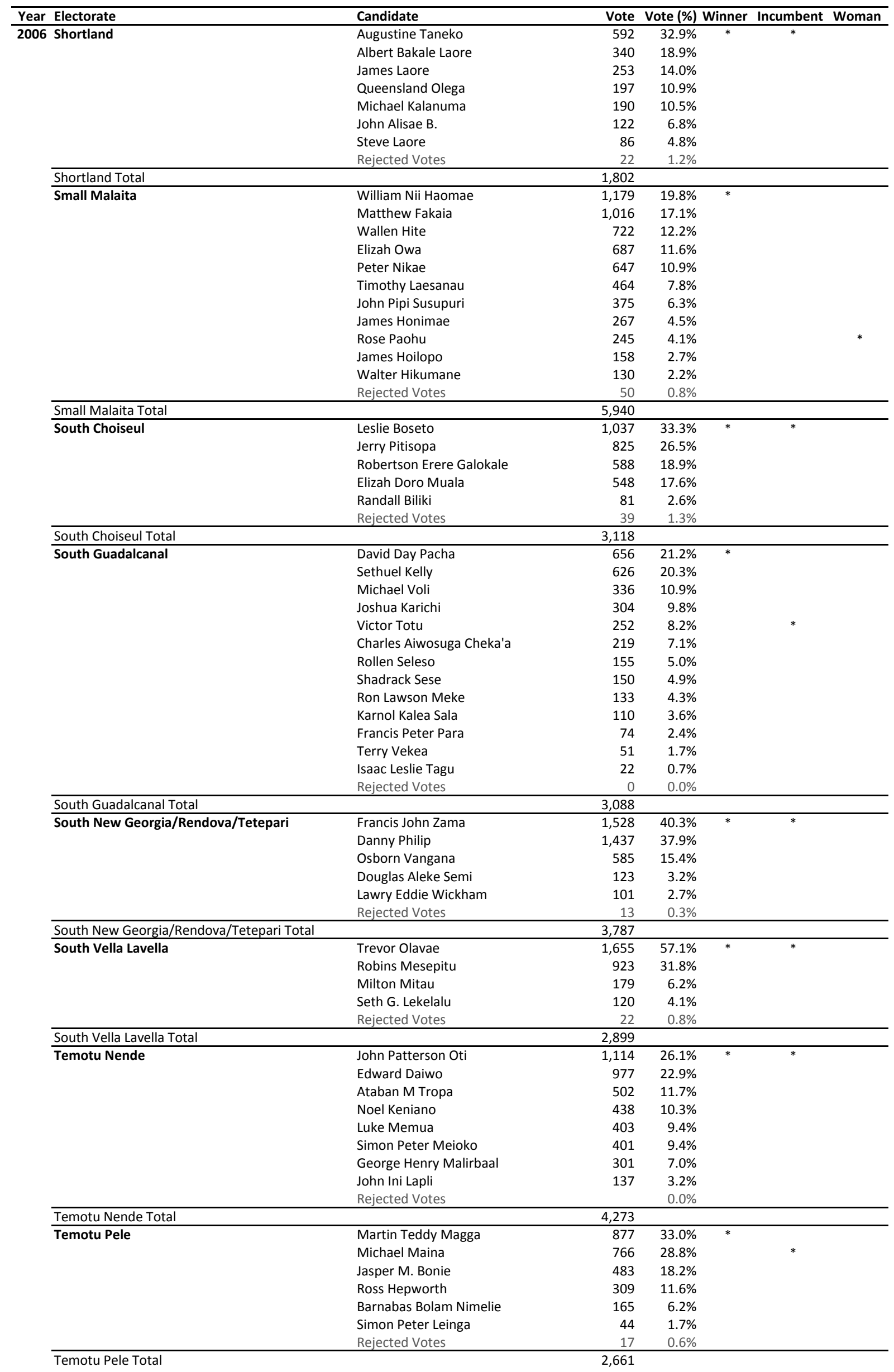


General Election Results

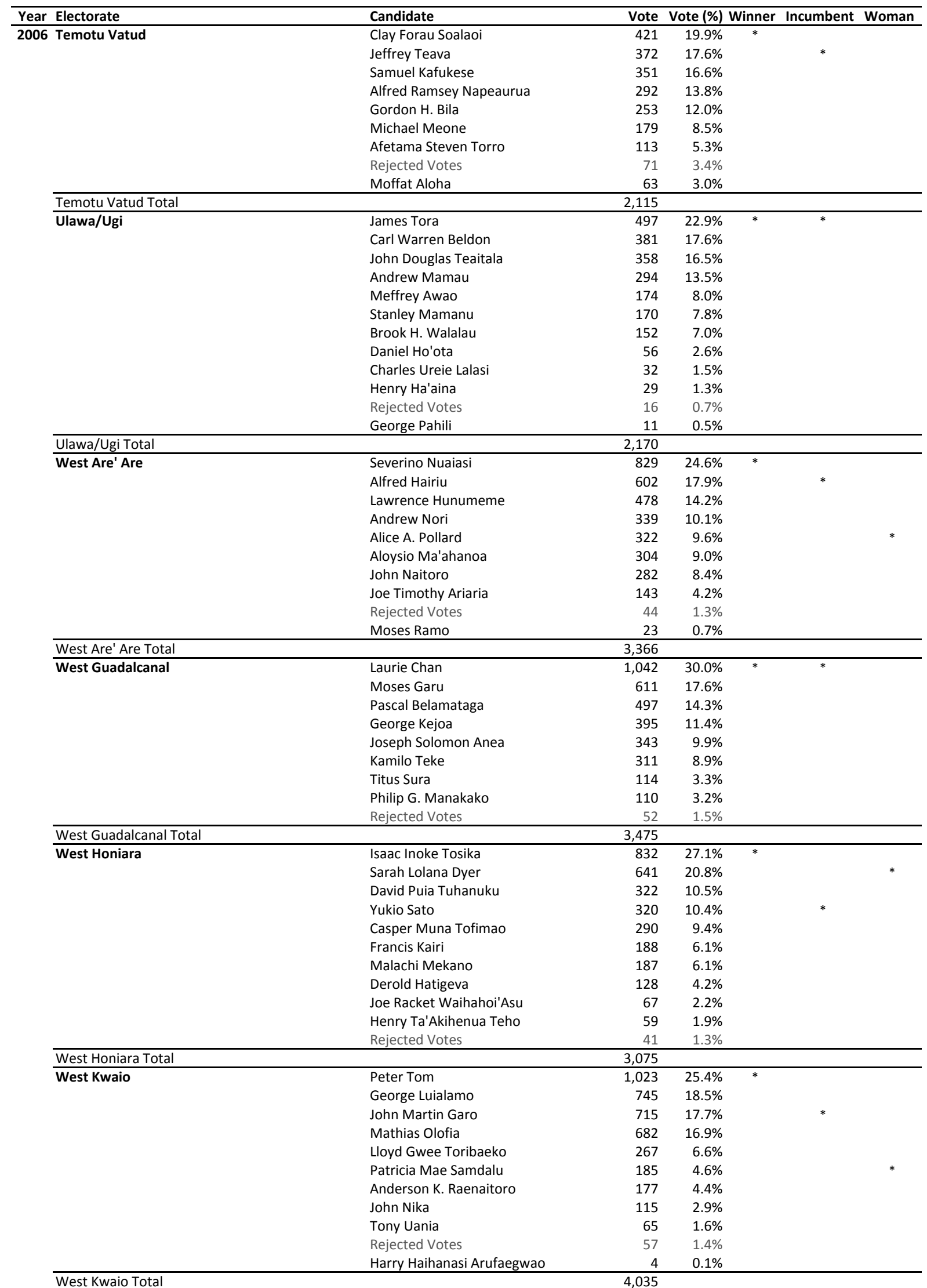




\begin{tabular}{|c|c|c|c|c|c|c|c|}
\hline Year & Electorate & Candidate & Vote & Vote (\%) & Winner & Incumbent & Woman \\
\hline \multirow[t]{46}{*}{2006} & West Kwara'ae & Sam Shemuel Iduri & 1,297 & $20.1 \%$ & $*$ & & \\
\hline & & Martin Aebata & 1,022 & $15.8 \%$ & & & \\
\hline & & David Dausabea & 597 & $9.2 \%$ & & & \\
\hline & & Rose Anilabata & 502 & $7.8 \%$ & & & $*$ \\
\hline & & Freddy Ratu Saenile & 457 & $7.1 \%$ & & & \\
\hline & & Andrew Loboi & 450 & $7.0 \%$ & & & \\
\hline & & Fagal Aengari & 358 & $5.5 \%$ & & & \\
\hline & & Paul Kukute Daokalia & 315 & $4.9 \%$ & & & \\
\hline & & John Alfred Tuasulia & 303 & $4.7 \%$ & & & \\
\hline & & Casper Joseph Fa'asala & 237 & $3.7 \%$ & & & \\
\hline & & Andrew Moli & 231 & $3.6 \%$ & & & \\
\hline & & Hudson Faitadi & 178 & $2.8 \%$ & & & \\
\hline & & Walton Willy Abuito'o & 165 & $2.6 \%$ & & & \\
\hline & & Robert Oi & 130 & $2.0 \%$ & & & \\
\hline & & Joses Naumai & 119 & $1.8 \%$ & & & \\
\hline & & John Donation Maefaididia & 78 & $1.2 \%$ & & & \\
\hline & & Joshua Waneta & 19 & $0.3 \%$ & & & \\
\hline & & Peter Indu & 9 & $0.1 \%$ & & & \\
\hline & & Rejected Votes & & $0.0 \%$ & & & \\
\hline & West Kwara'ae Total & & 6,467 & & & & \\
\hline & West Makira & Japhet Waipora & 790 & $19.4 \%$ & * & & \\
\hline & & Jackson Sunaone & 767 & $18.8 \%$ & & & \\
\hline & & Ben Hoda Mato'o & 338 & $8.3 \%$ & & & \\
\hline & & John Mark Huta & 320 & $7.8 \%$ & & & \\
\hline & & Dick Ha'amori & 310 & $7.6 \%$ & & & \\
\hline & & David Bo'orauniara Aitora & 282 & $6.9 \%$ & & & \\
\hline & & Mathias Taro & 259 & $6.4 \%$ & & $*$ & \\
\hline & & Charles Stennett Kereau & 187 & $4.6 \%$ & & & \\
\hline & & David Wakasi & 175 & $4.3 \%$ & & & \\
\hline & & Haga Mataroha John Palmer & 127 & $3.1 \%$ & & & \\
\hline & & Clara Rebitai & 120 & $2.9 \%$ & & & $*$ \\
\hline & & Thompson Orimatawa & 106 & $2.6 \%$ & & & \\
\hline & & Peter Tahaani & 79 & $1.9 \%$ & & & \\
\hline & & Kennedy Hoda & 65 & $1.6 \%$ & & & \\
\hline & & Rejected Votes & 61 & $1.5 \%$ & & & \\
\hline & & Michael Saiki Waokahi & 47 & $1.2 \%$ & & & \\
\hline & & Leslie Gua & 45 & $1.1 \%$ & & & \\
\hline & West Makira Total & & 4,078 & & & & \\
\hline & West New Georgia/Vona Vona & Peter James Boyers & 1,699 & $34.3 \%$ & * & * & \\
\hline & & John Deane Kuku & 926 & $18.7 \%$ & & & \\
\hline & & Andrew Prakash & 853 & $17.2 \%$ & & & \\
\hline & & Ashley Wickham & 795 & $16.0 \%$ & & & \\
\hline & & Nuatali Tongarutu & 331 & $6.7 \%$ & & & $*$ \\
\hline & & Warren Paia & 209 & $4.2 \%$ & & & \\
\hline & & Wilson Gina & 78 & $1.6 \%$ & & & \\
\hline & & Rejected Votes & 68 & $1.4 \%$ & & & \\
\hline
\end{tabular}


General Election Results

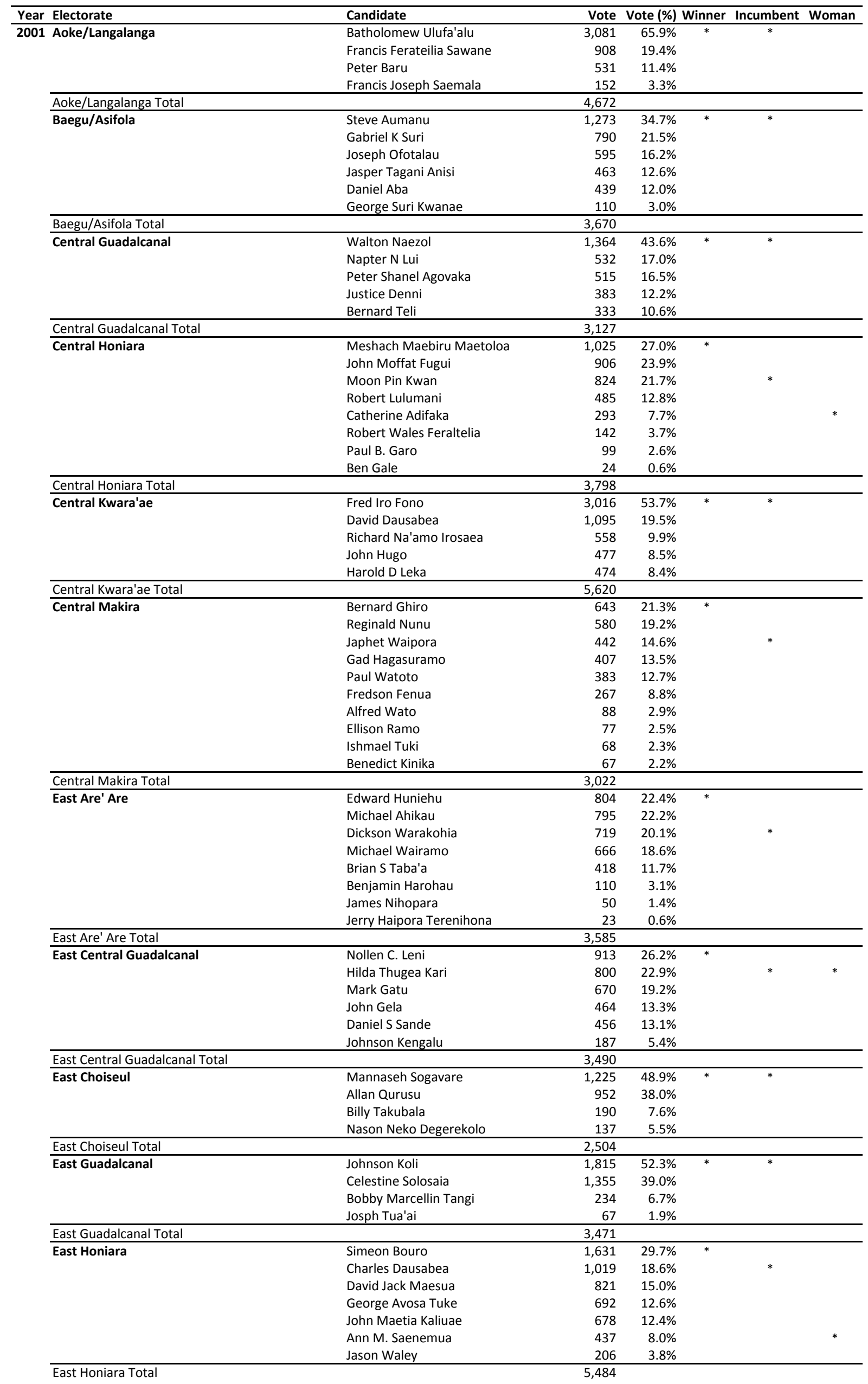




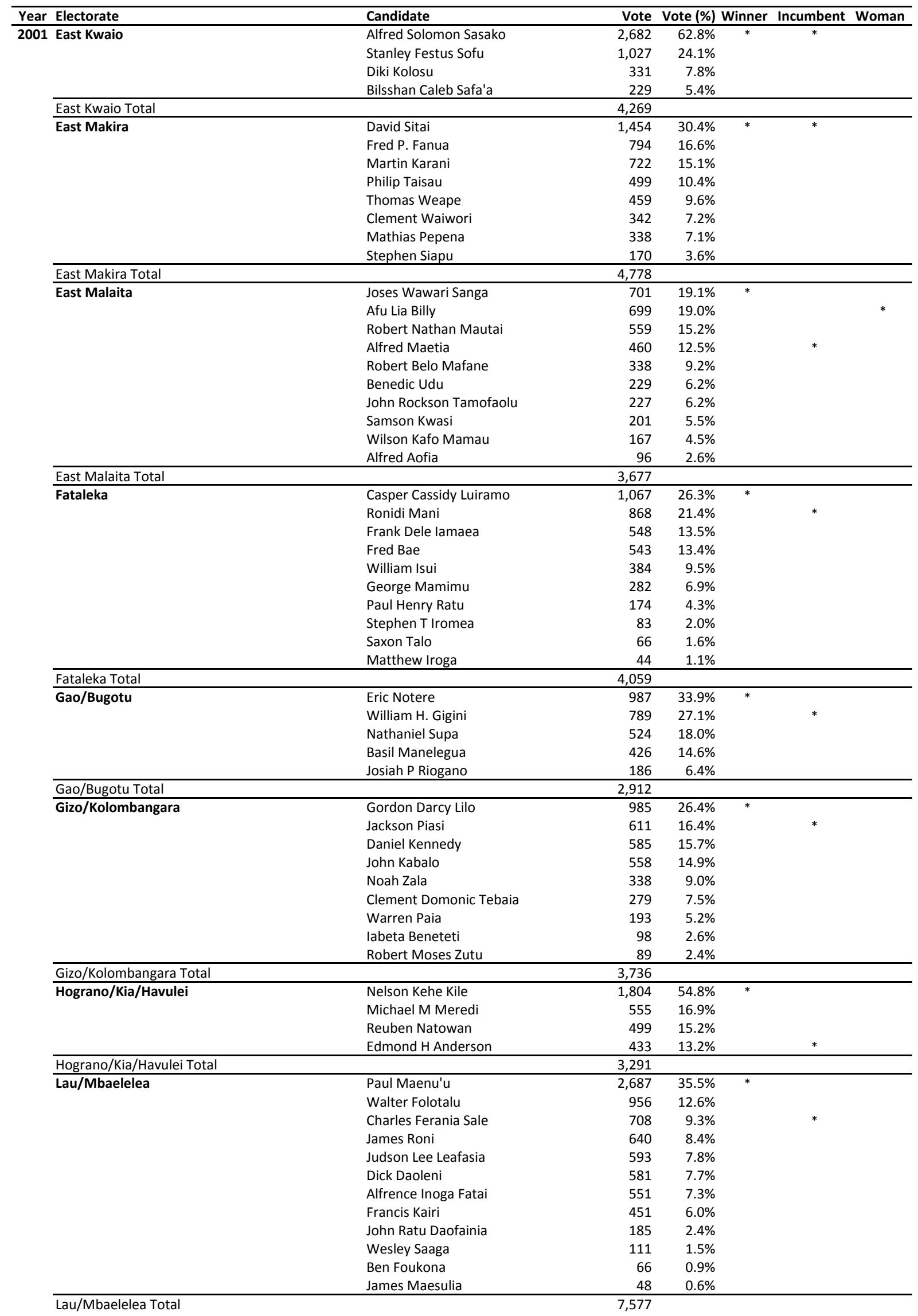


General Election Results

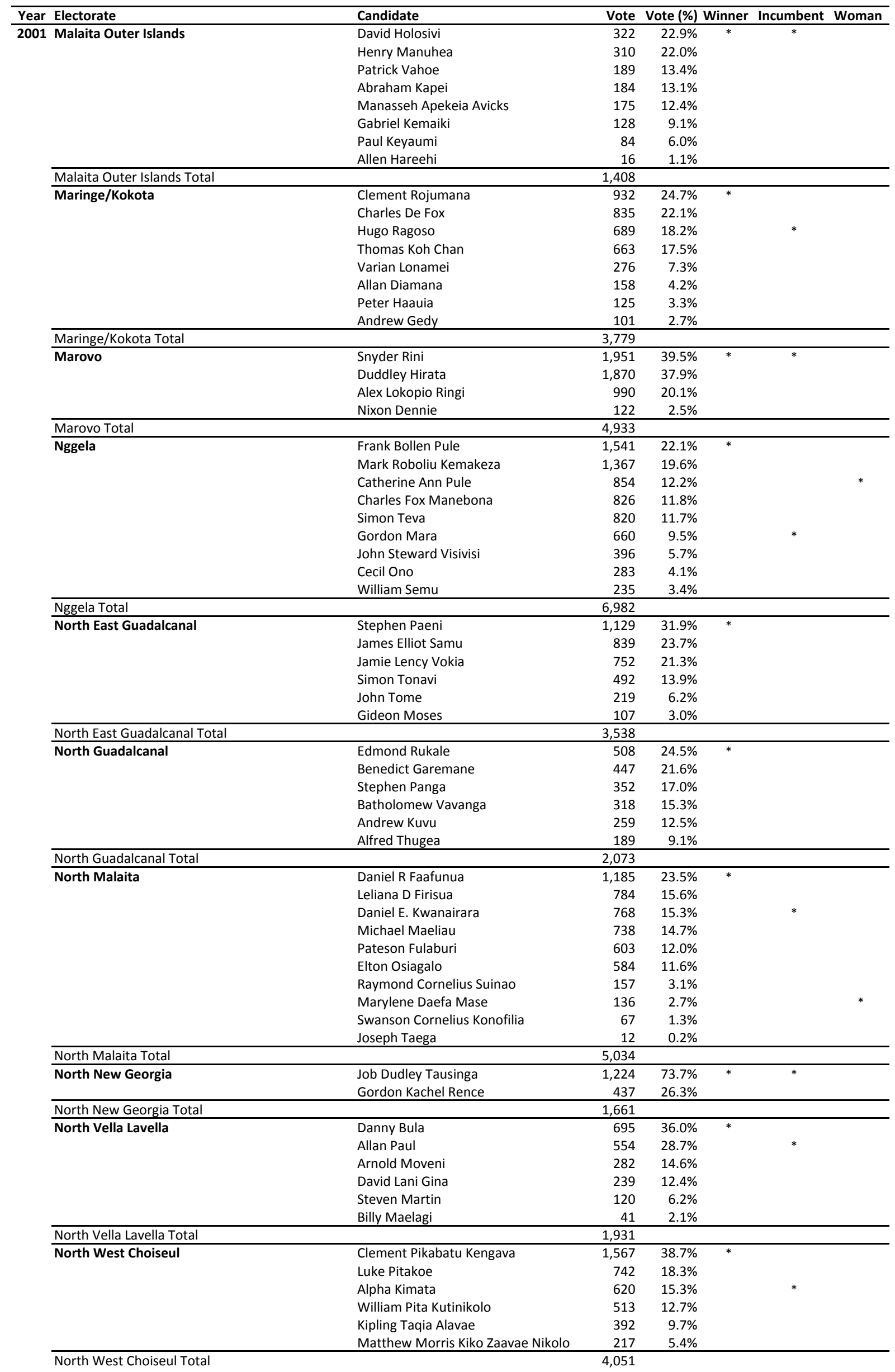


General Election Results

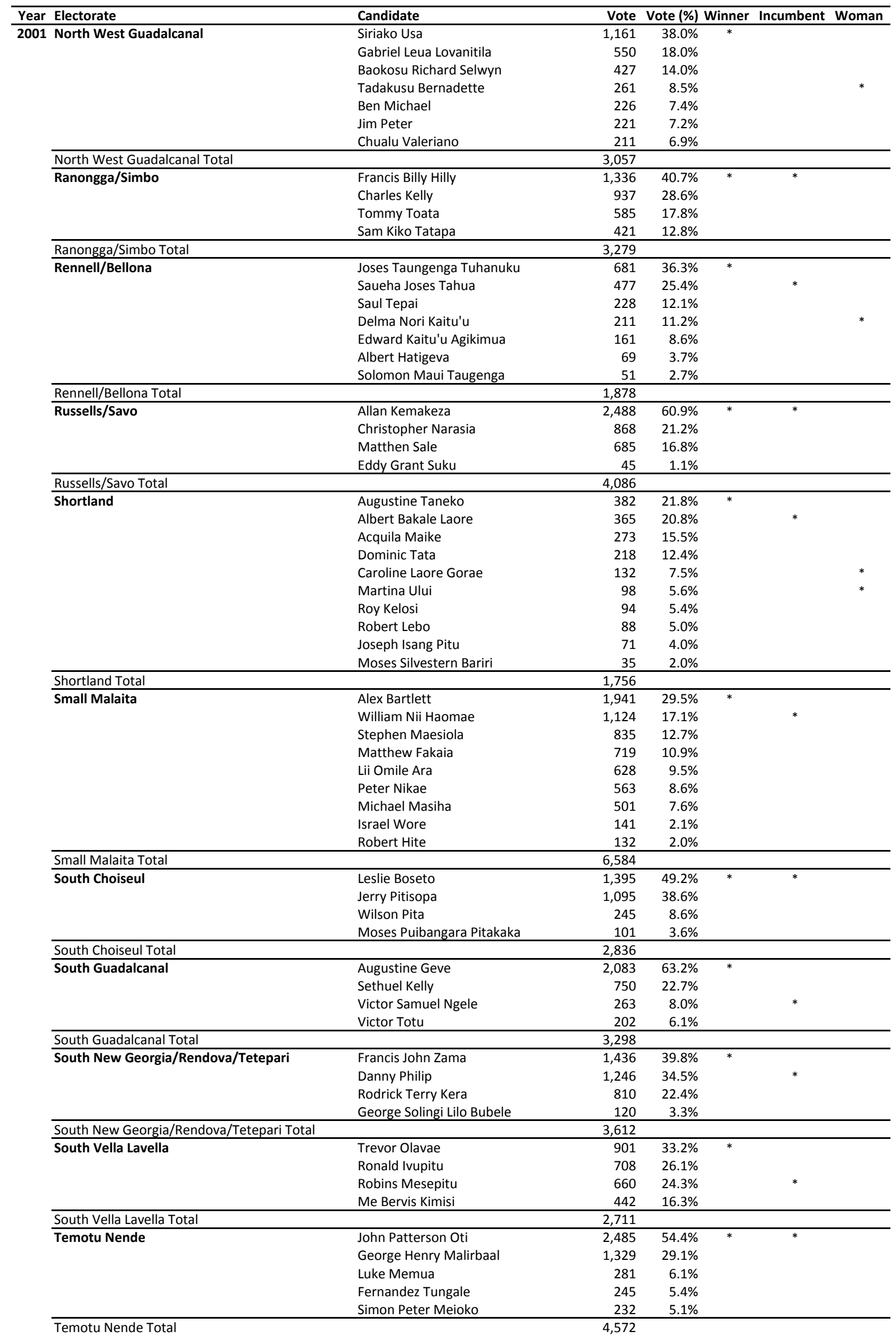


General Election Results

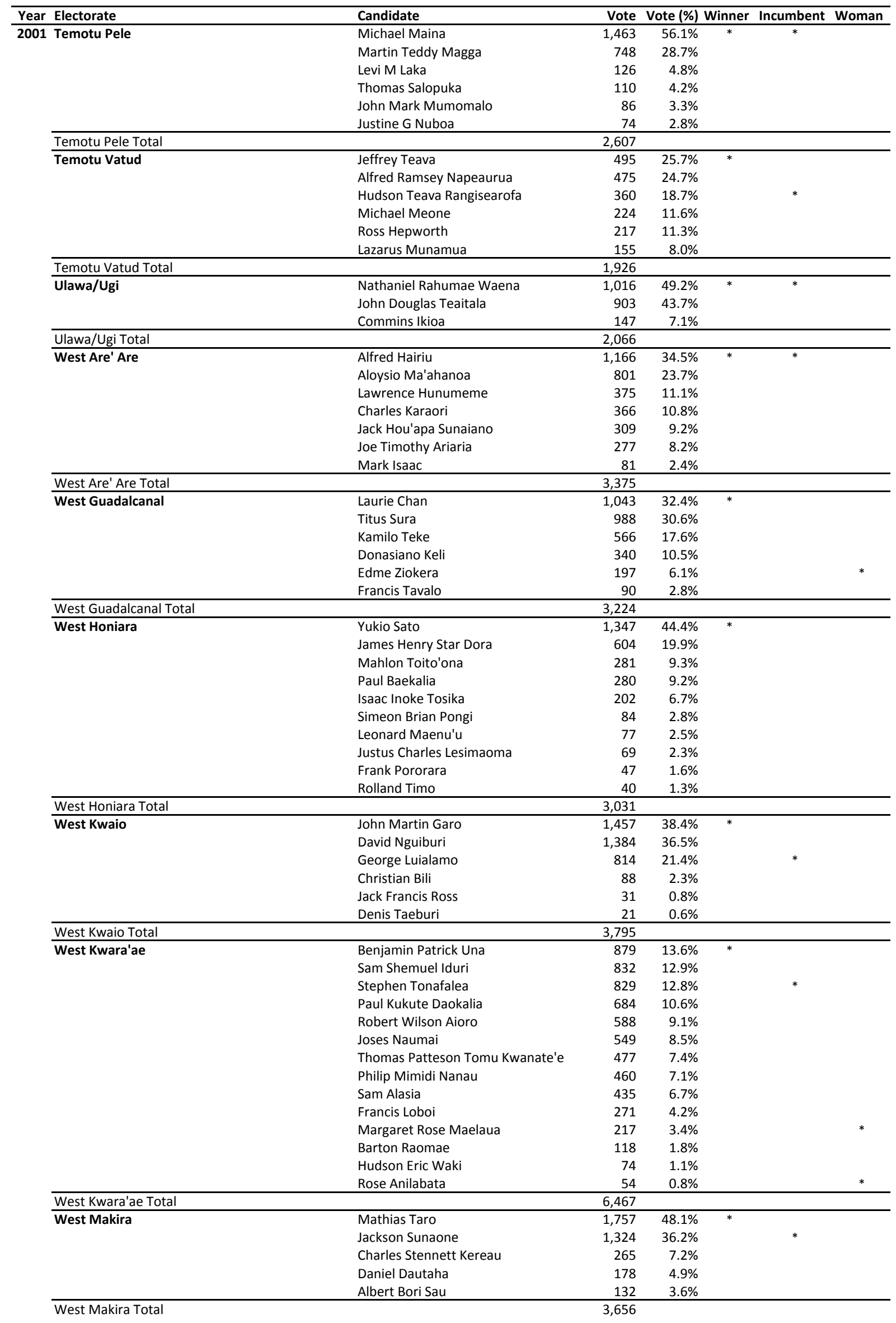


General Election Results

\begin{tabular}{|c|c|c|c|c|c|c|c|}
\hline \multirow{2}{*}{\multicolumn{2}{|c|}{$\begin{array}{l}\text { Year Electorate } \\
2001 \text { West New Georgia/Vona Vona }\end{array}$}} & Candidate & Vote & Vote (\%) & Winner & Incumbent & Woman \\
\hline \multirow[t]{9}{*}{2001} & & Peter James Boyers & 845 & $20.9 \%$ & $*$ & \multirow{9}{*}{$*$} & \multirow{9}{*}{$*$} \\
\hline & & Charles Kere & 781 & $19.3 \%$ & & & \\
\hline & & Ashley Wickham & 539 & $13.3 \%$ & & & \\
\hline & & Nelson Boso & 482 & $11.9 \%$ & & & \\
\hline & & Nuatali Tongarutu & 435 & $10.8 \%$ & & & \\
\hline & & John Talasasa & 419 & $10.4 \%$ & & & \\
\hline & & Ronald Kuba Ziru & 262 & $6.5 \%$ & & & \\
\hline & & Allan H Tekulu & 201 & $5.0 \%$ & & & \\
\hline & & Edward Daga & 81 & $2.0 \%$ & & & \\
\hline
\end{tabular}

West New Georgia/Vona Vona Total

4,045 
General Election Results

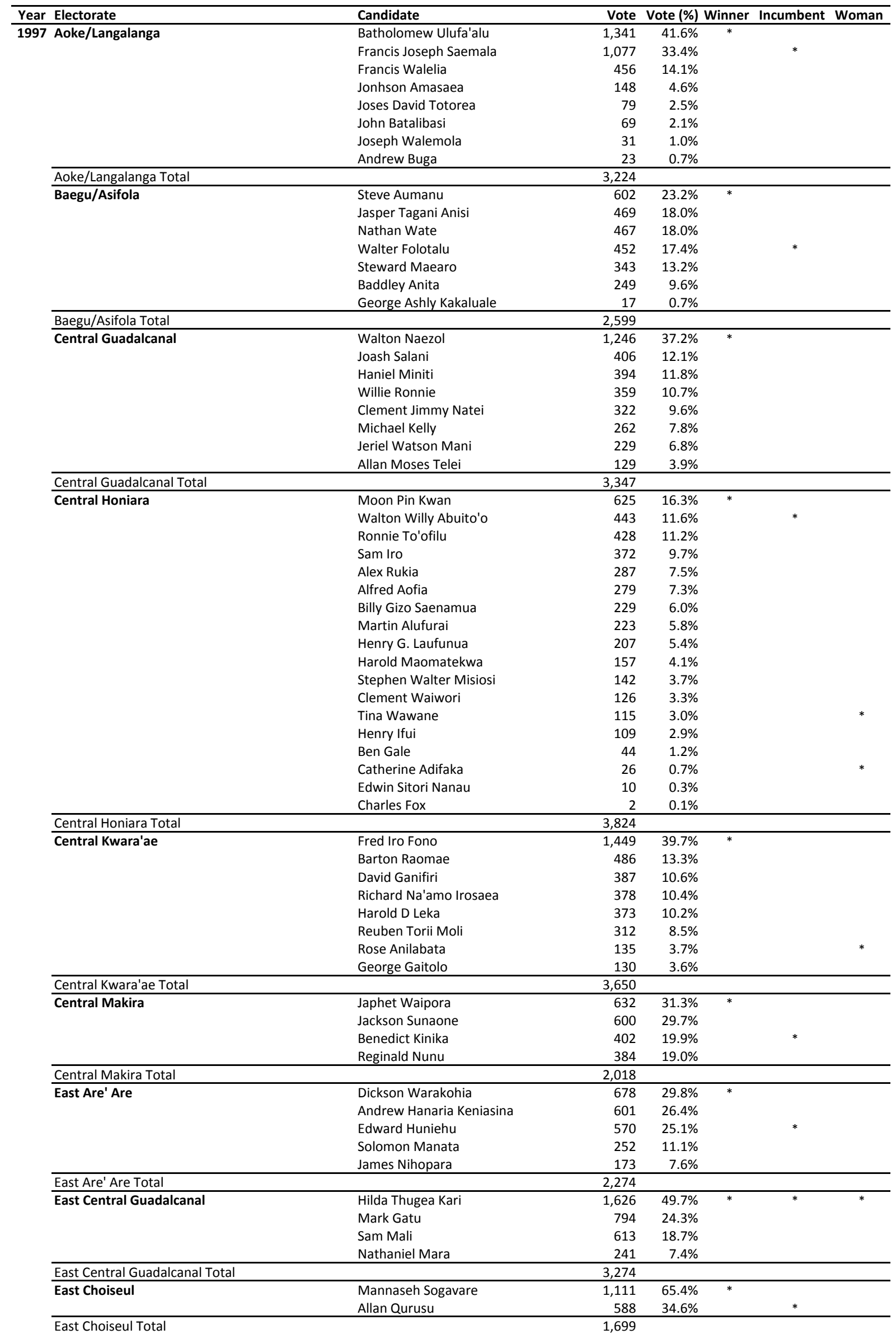


General Election Results

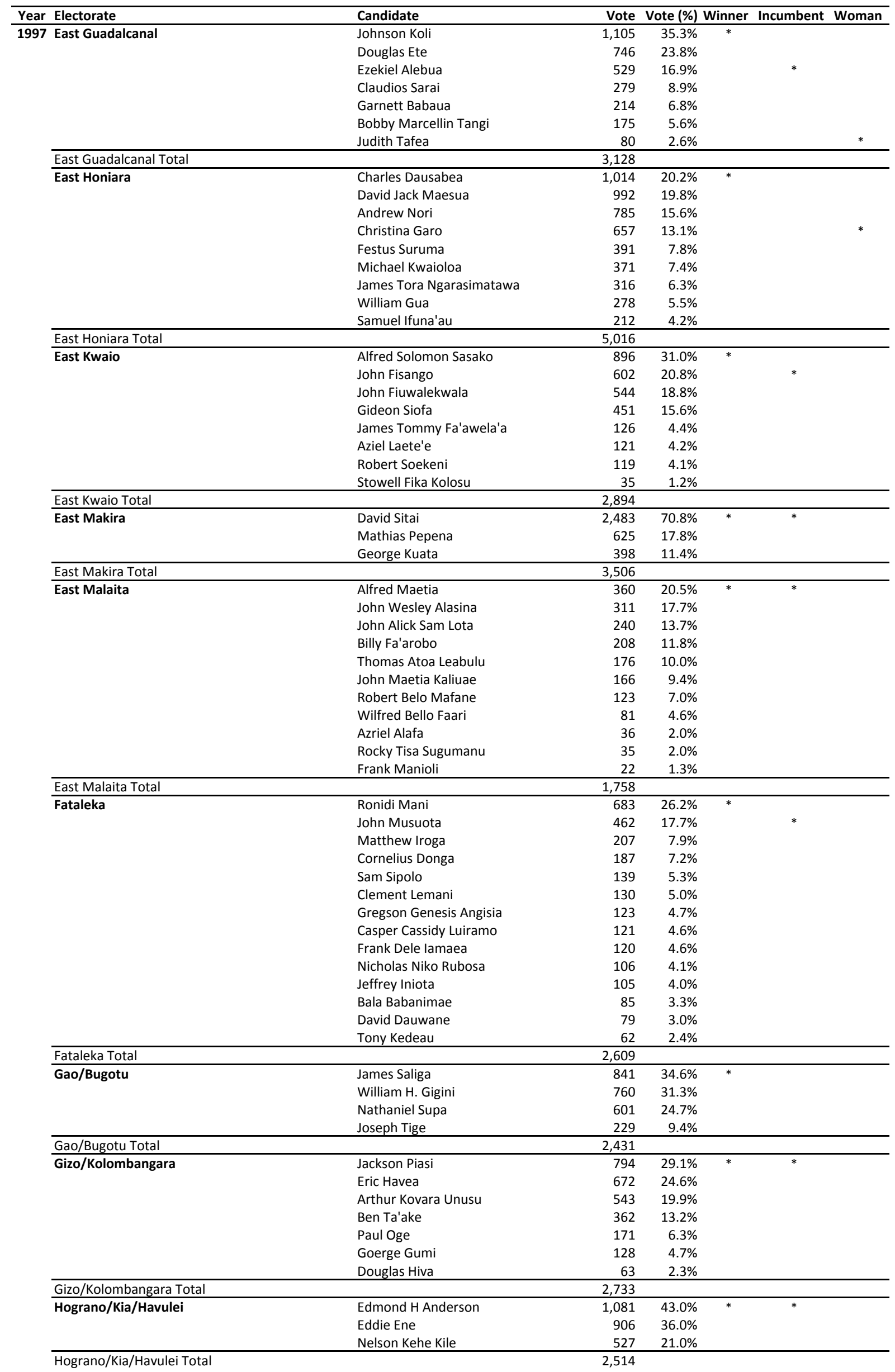




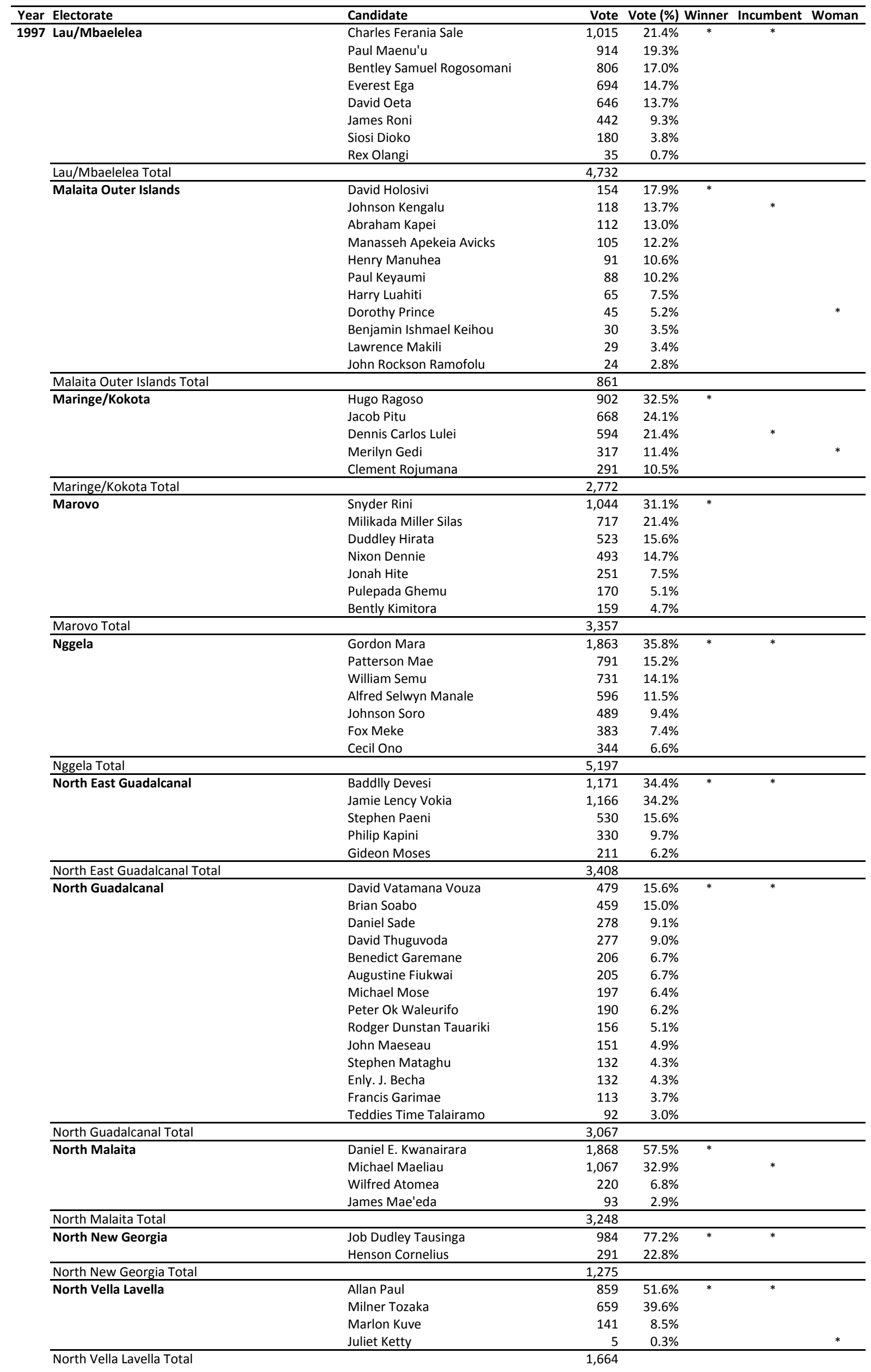


General Election Results

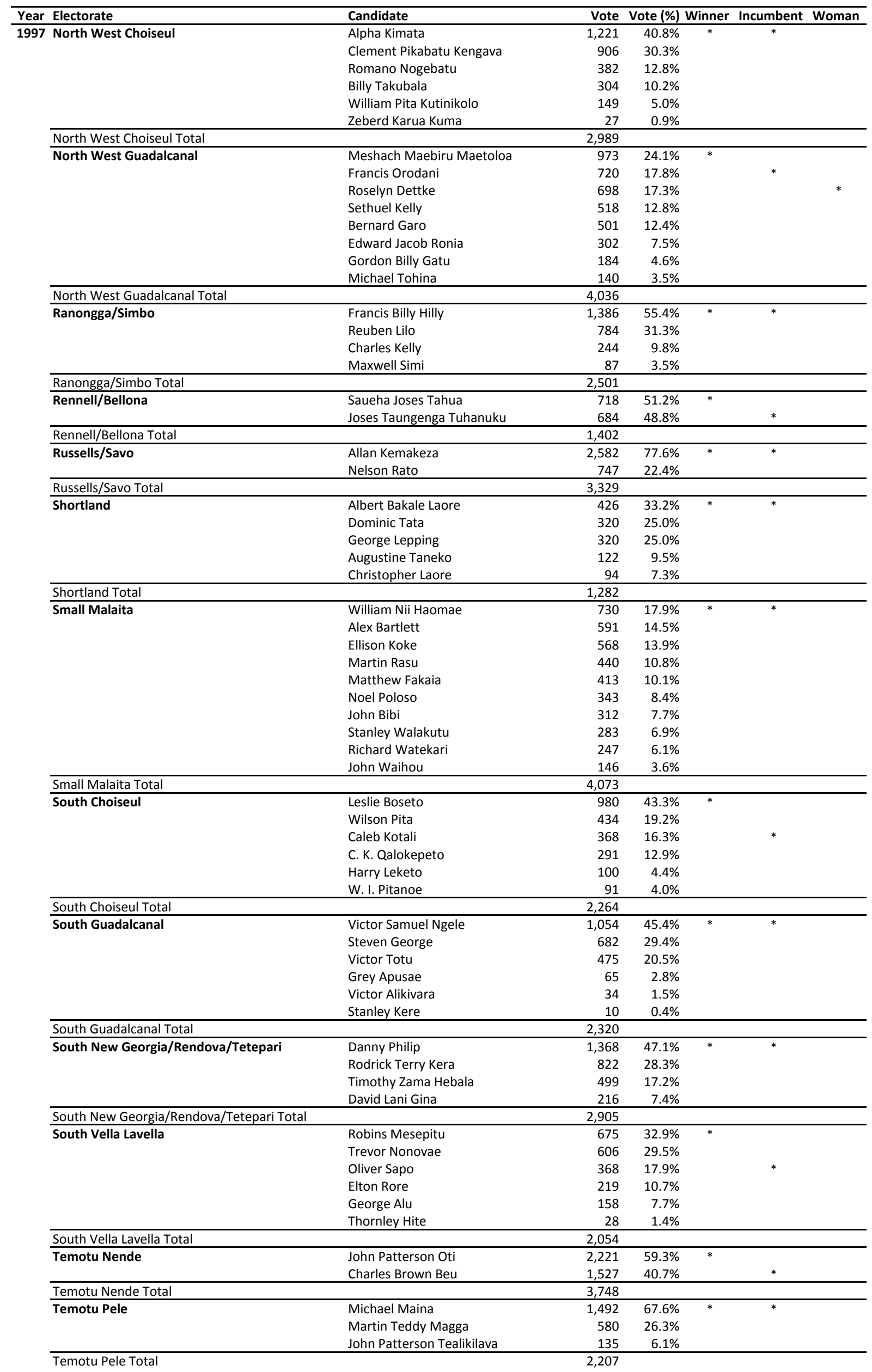




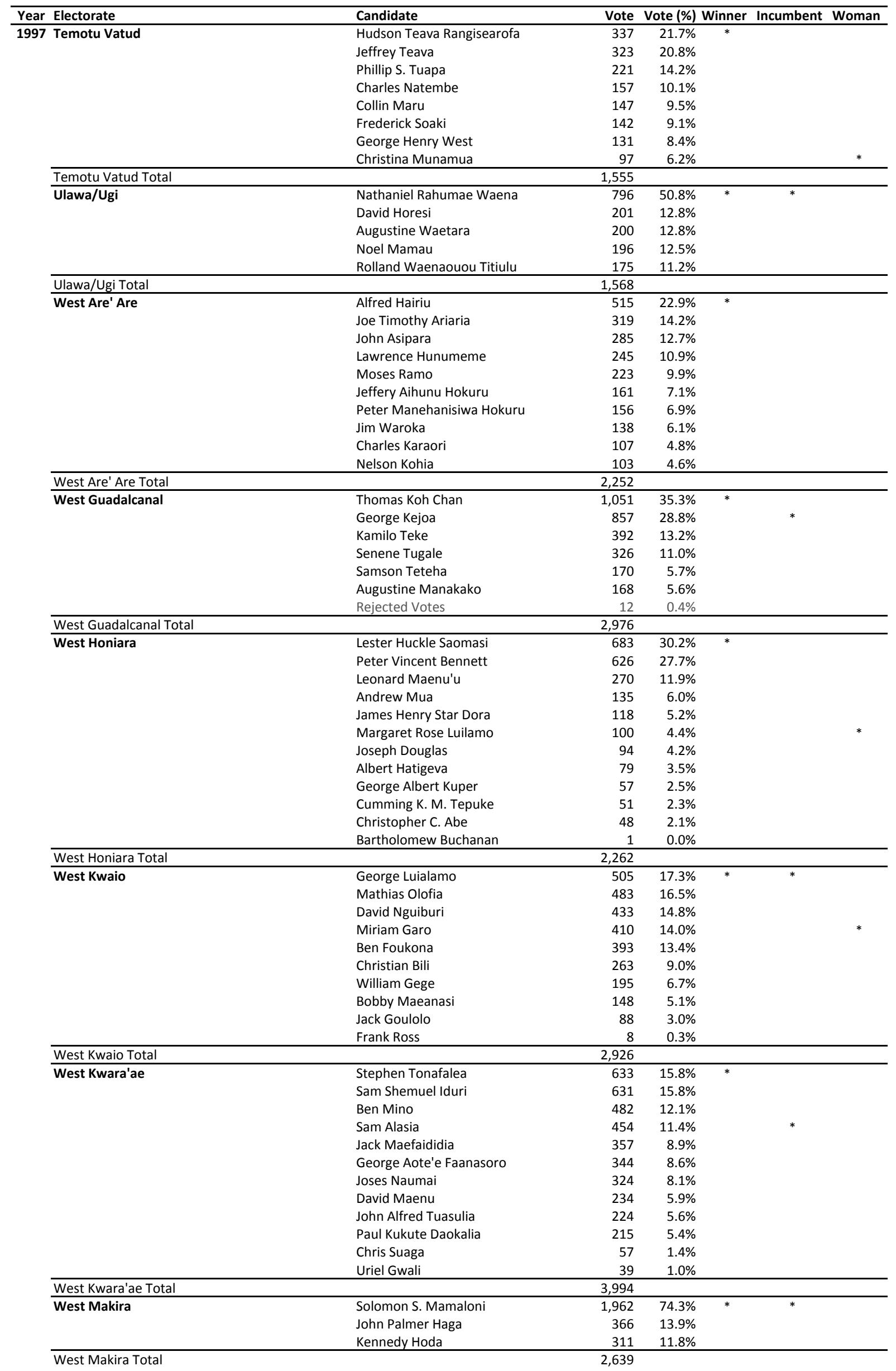


General Election Results

Year Electorate

1997 West New Georgia/Vona Vona

Candidate

Nelson Boso

Aquila Talasasa

Hugh Soakai

Merlie Aqorau

Ronald Kuba Ziru

George Tuke

West New Georgia/Vona Vona Total
Vote Vote (\%) Winner Incumbent Woman

$1,112 \quad 30.6 \%$

$848 \quad 23.3 \%$

$773 \quad 21.3 \%$

$388 \quad 10.7 \%$

$313 \quad 8.6 \%$

$202 \quad 5.6 \%$ 


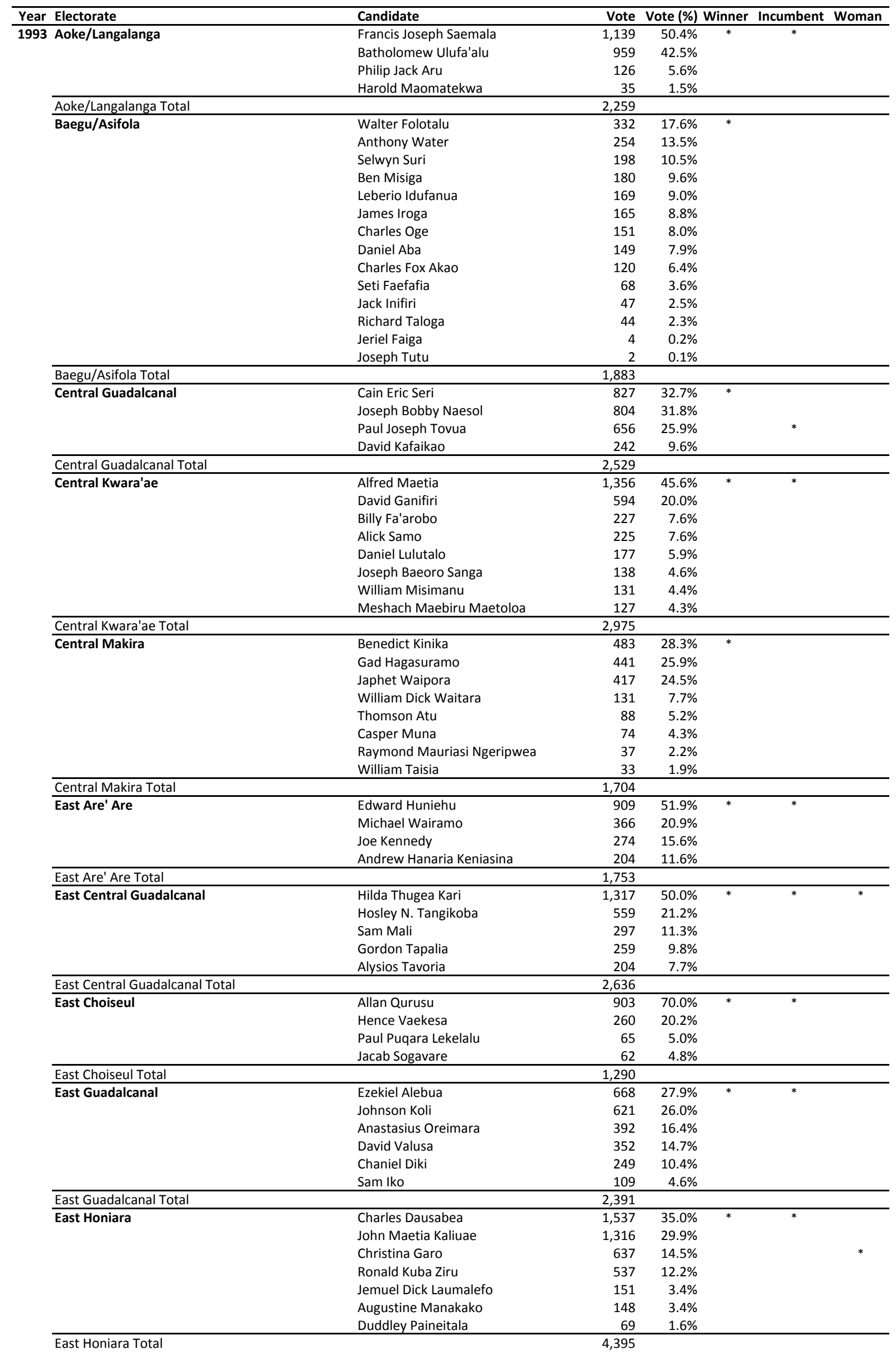


General Election Results

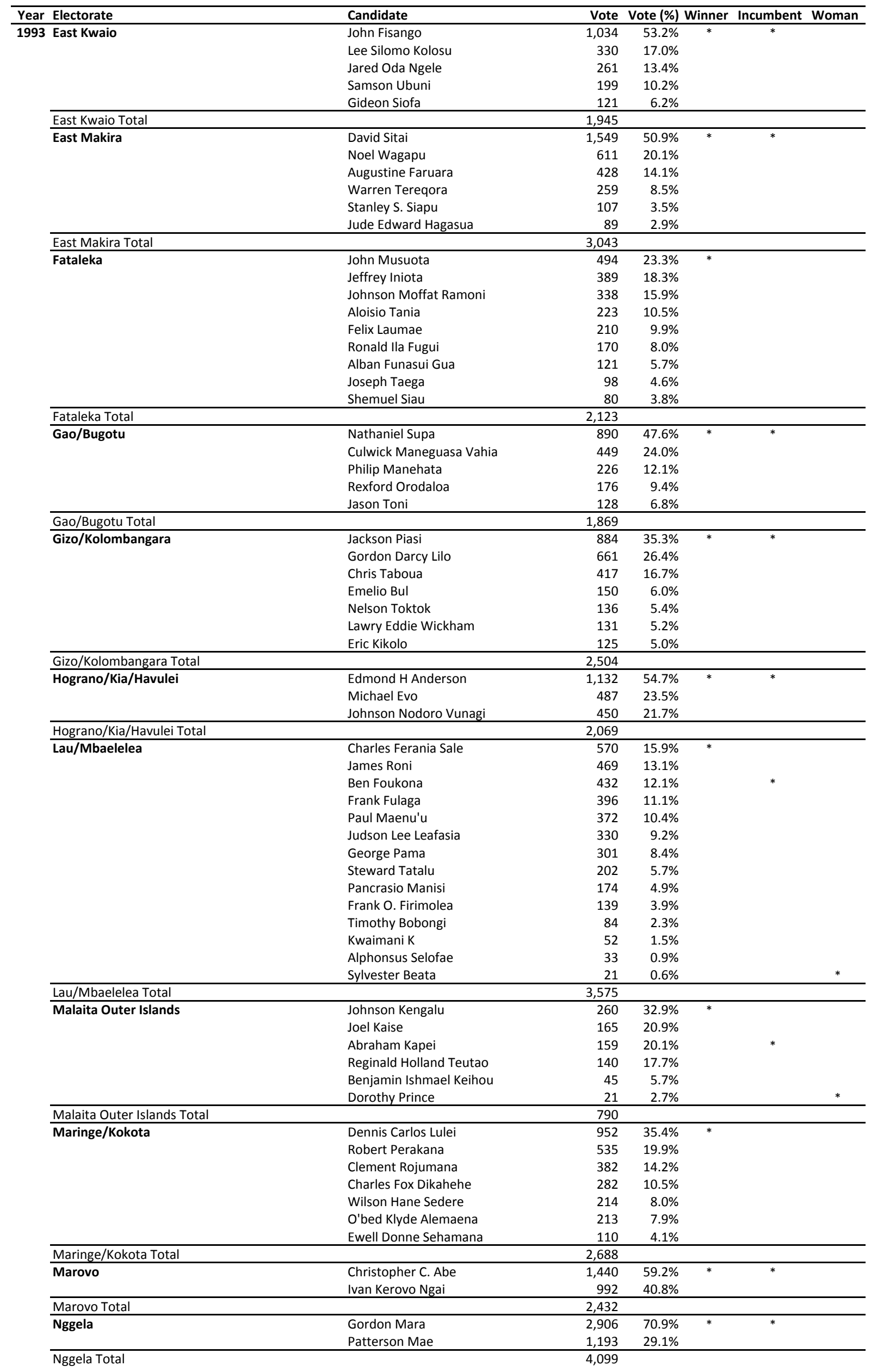




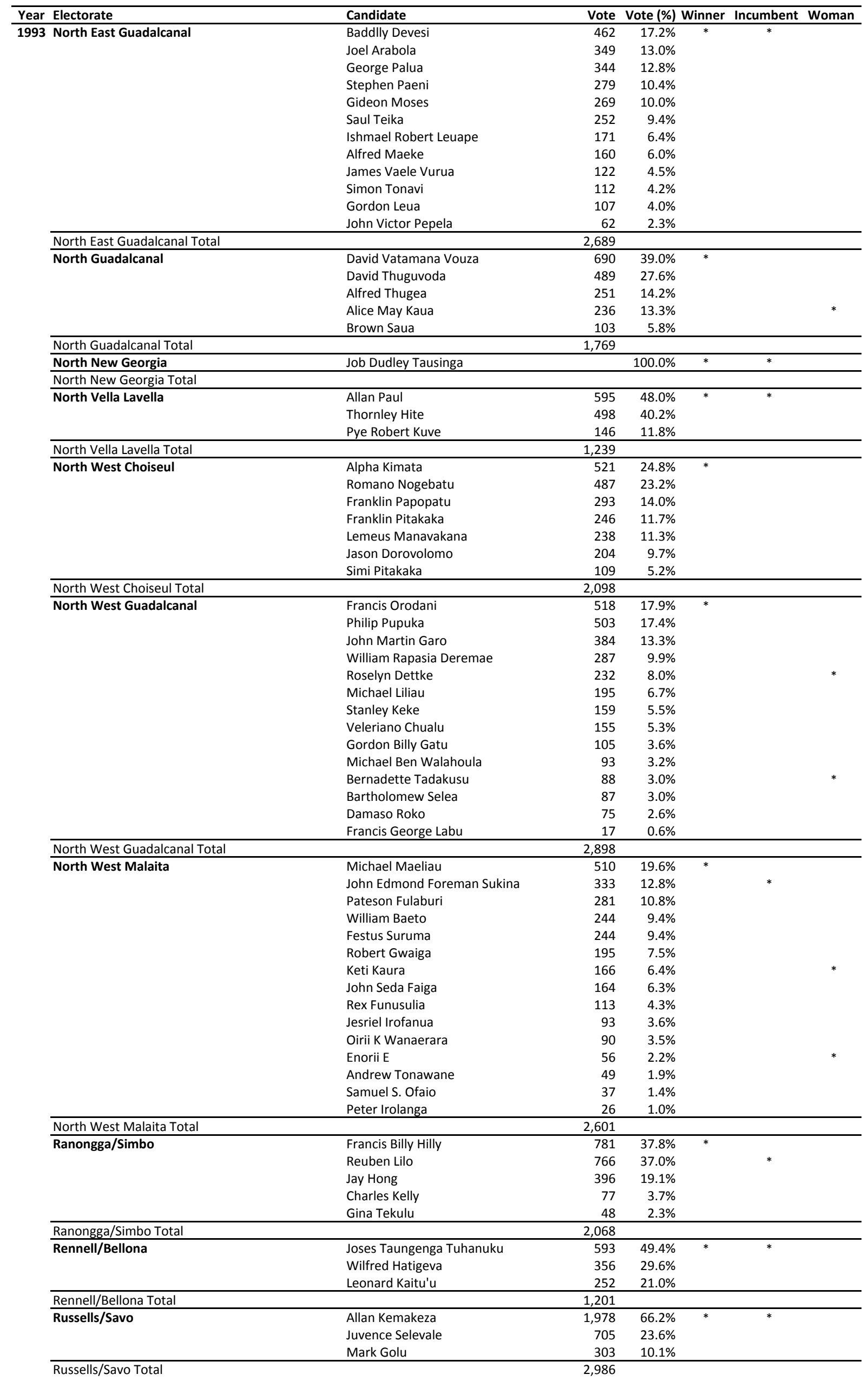




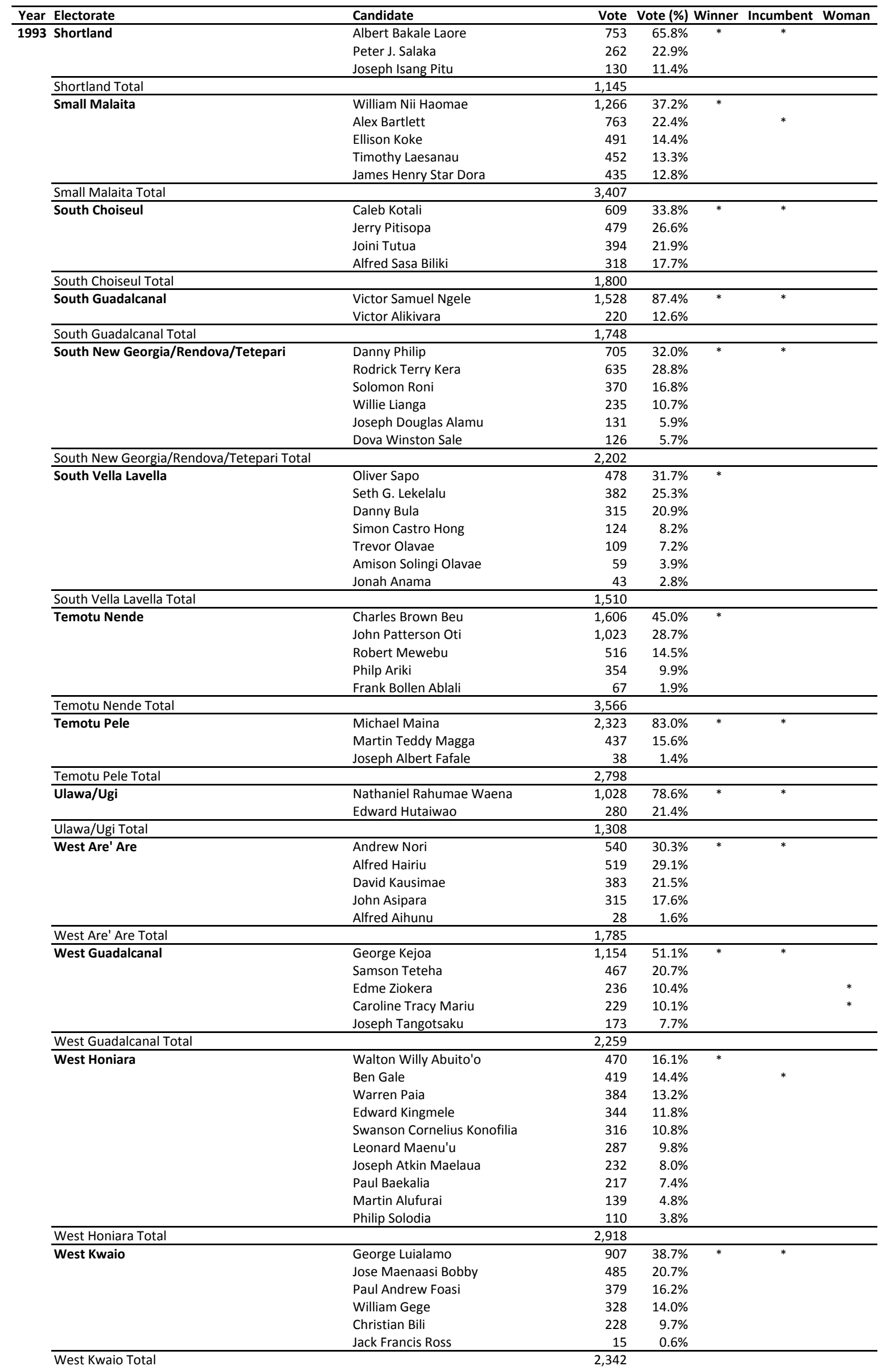


General Election Results

\begin{tabular}{|c|c|c|c|c|c|c|c|}
\hline Year & Electorate & Candidate & Vote & Vote (\%) & Winner & Incumbent & Woman \\
\hline \multirow[t]{22}{*}{1993} & West Kwara'ae & Sam Alasia & 1,356 & $31.6 \%$ & $*$ & $*$ & \\
\hline & & Dioko Funufaka & 742 & $17.3 \%$ & & & \\
\hline & & Stephen Tonafalea & 723 & $16.9 \%$ & & & \\
\hline & & Mathew Edward Maefai & 525 & $12.2 \%$ & & & \\
\hline & & Malcolm Maefilia & 463 & $10.8 \%$ & & & \\
\hline & & Robert Wilson Aioro & 176 & $4.1 \%$ & & & \\
\hline & & Chris Suaga & 166 & $3.9 \%$ & & & \\
\hline & & Collin Gauwane & 135 & $3.1 \%$ & & & \\
\hline & West Kwara'ae Total & & 4,286 & & & & \\
\hline & West Makira & Solomon S. Mamaloni & & $100.0 \%$ & * & * & \\
\hline & West Makira Total & & & & & & \\
\hline & West New Georgia/Vona Vona & Nelson Boso & 516 & $18.9 \%$ & * & & \\
\hline & & David Ernest Kera & 445 & $16.3 \%$ & & & \\
\hline & & Holmes Patao Saeva & 434 & $15.9 \%$ & & & \\
\hline & & Binet Gadebeta & 306 & $11.2 \%$ & & & \\
\hline & & Benjo Patterson Runikera & 248 & $9.1 \%$ & & & \\
\hline & & Ian Kopele Talasasa & 220 & $8.0 \%$ & & & \\
\hline & & Matson Doava Gasimata & 217 & $7.9 \%$ & & & \\
\hline & & Hugh Soakai & 214 & $7.8 \%$ & & & \\
\hline & & John Talasasa & 110 & $4.0 \%$ & & & \\
\hline & & Mark Voda Bisili & 27 & $1.0 \%$ & & & \\
\hline & West New Georgia/Vona Vona T & & 2,737 & & & & \\
\hline
\end{tabular}




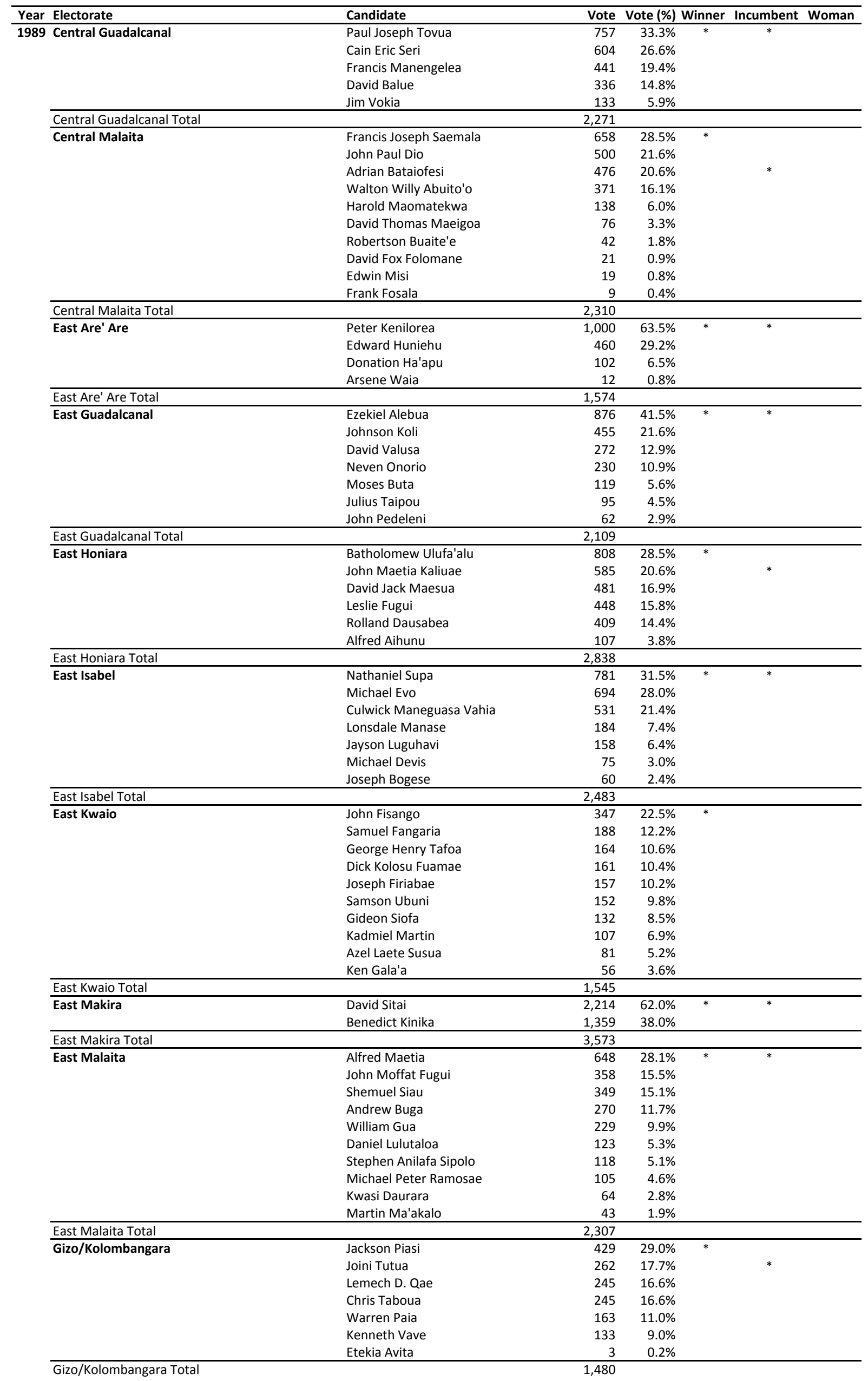




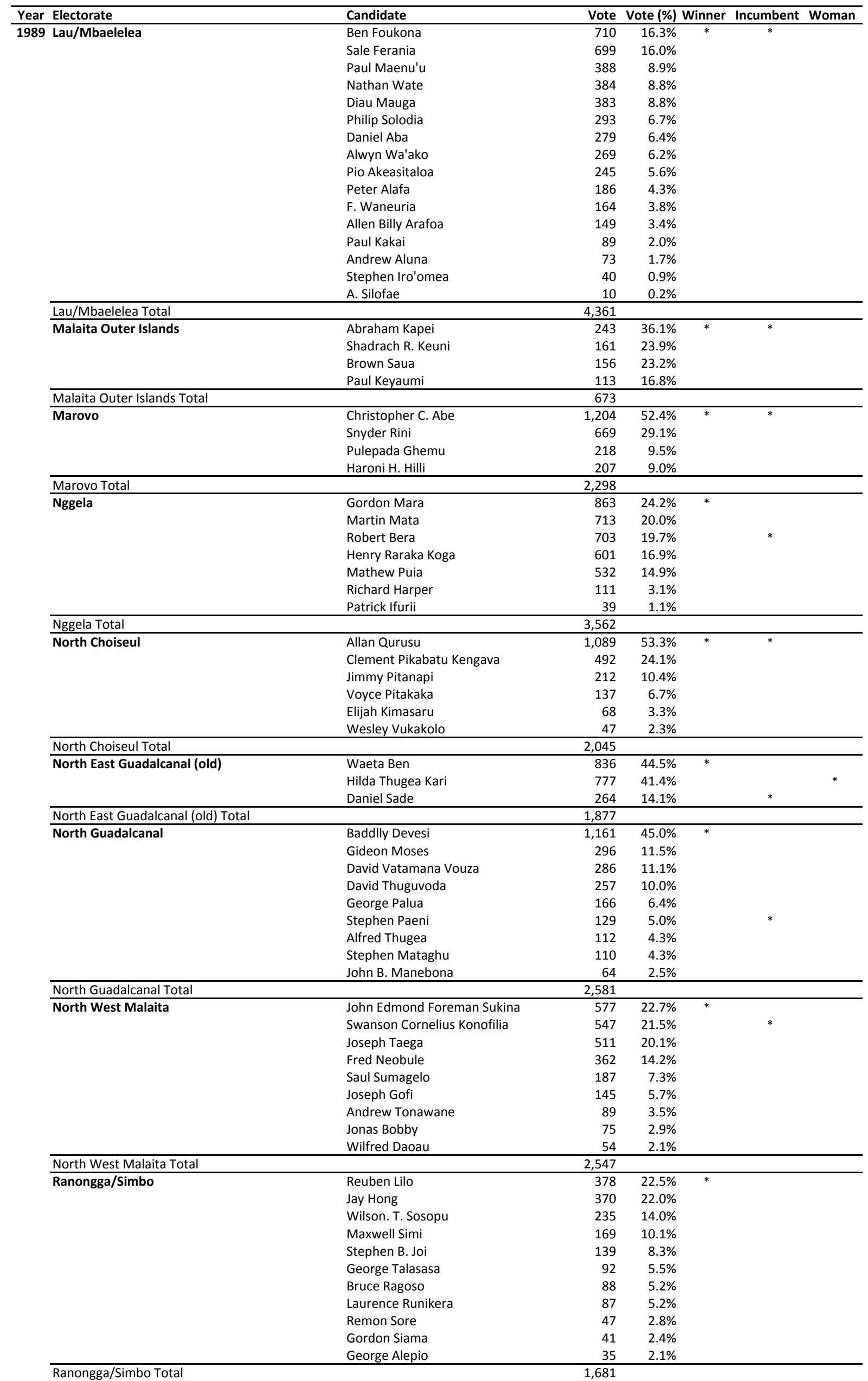


General Election Results

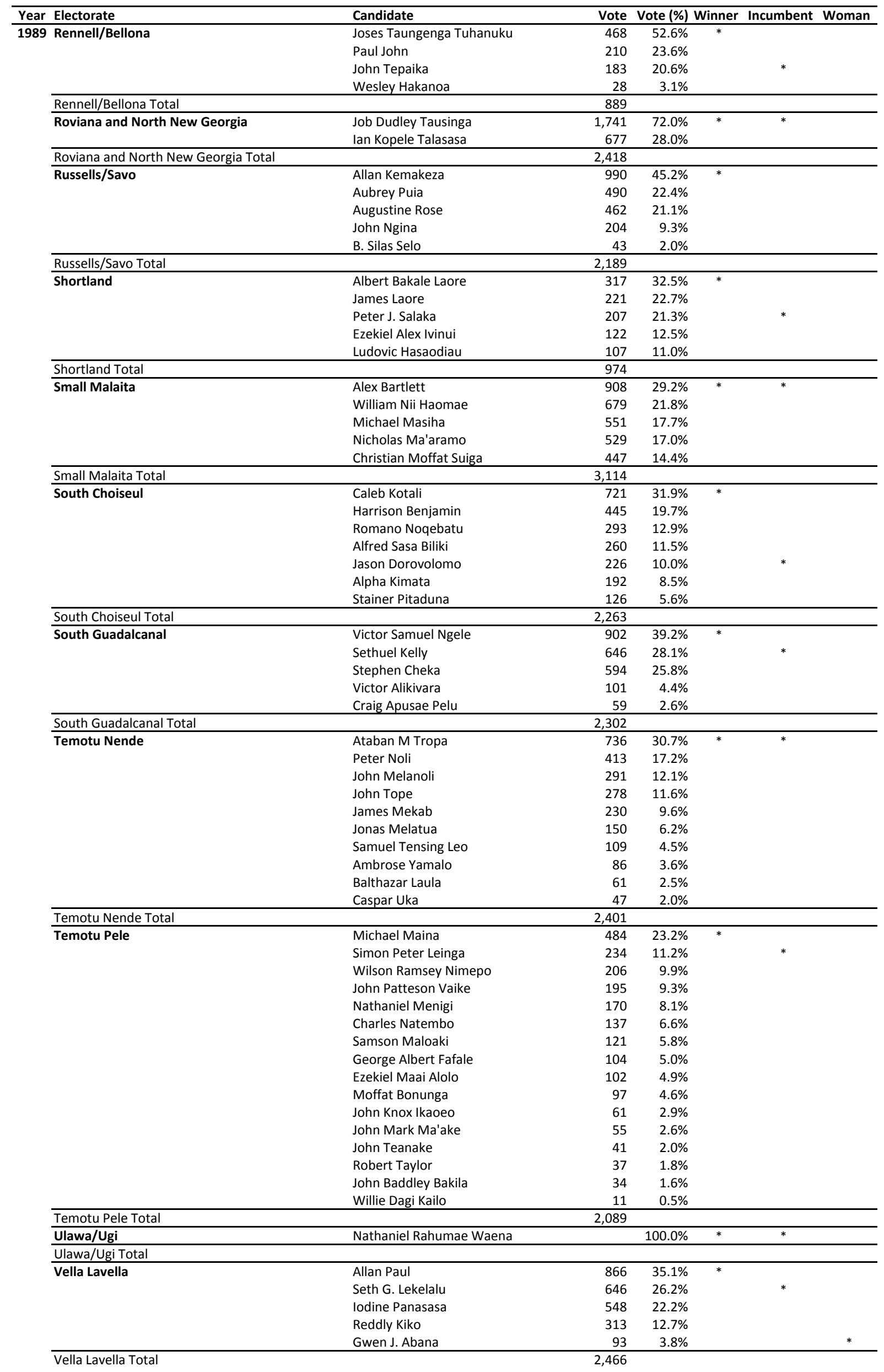


General Election Results

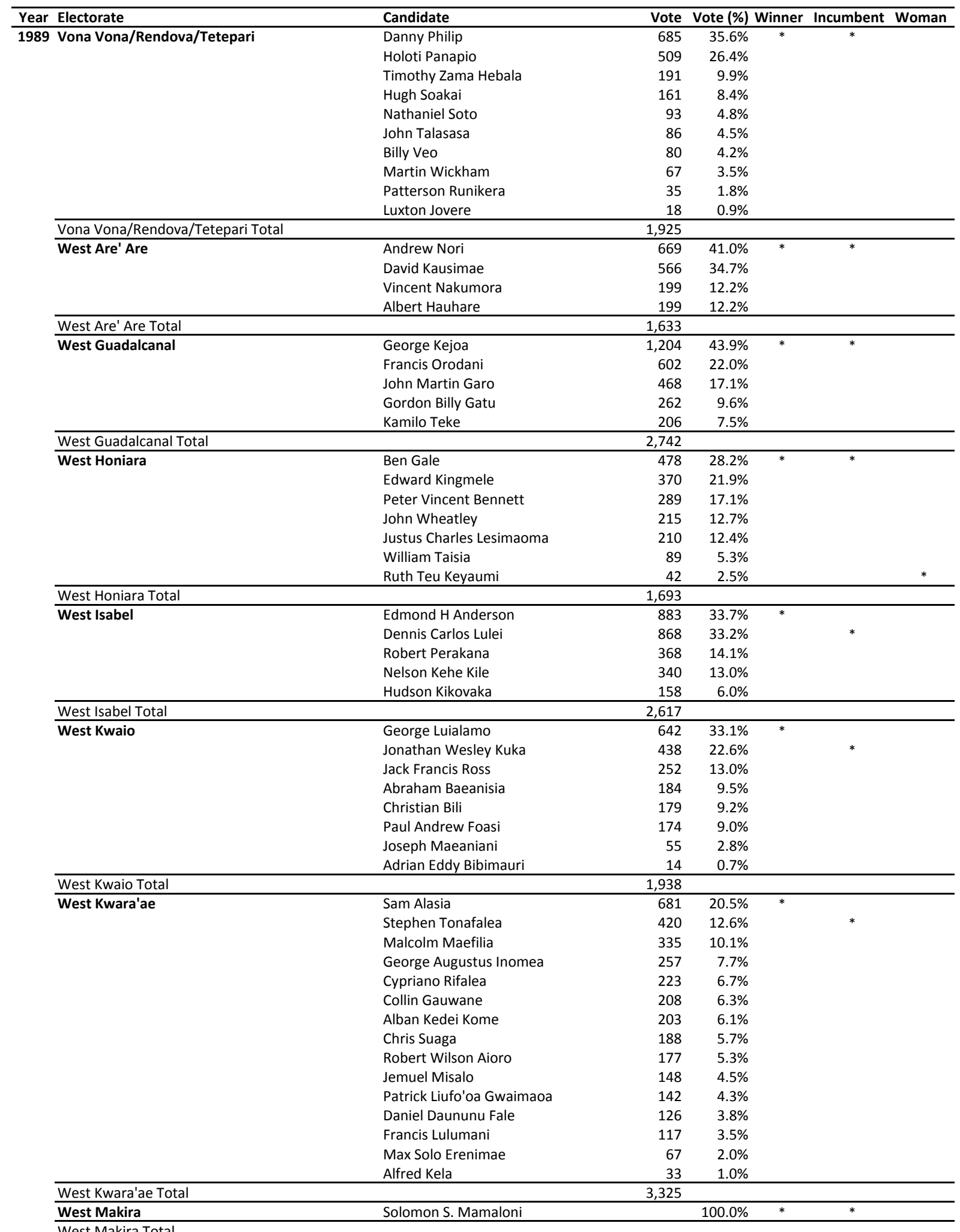




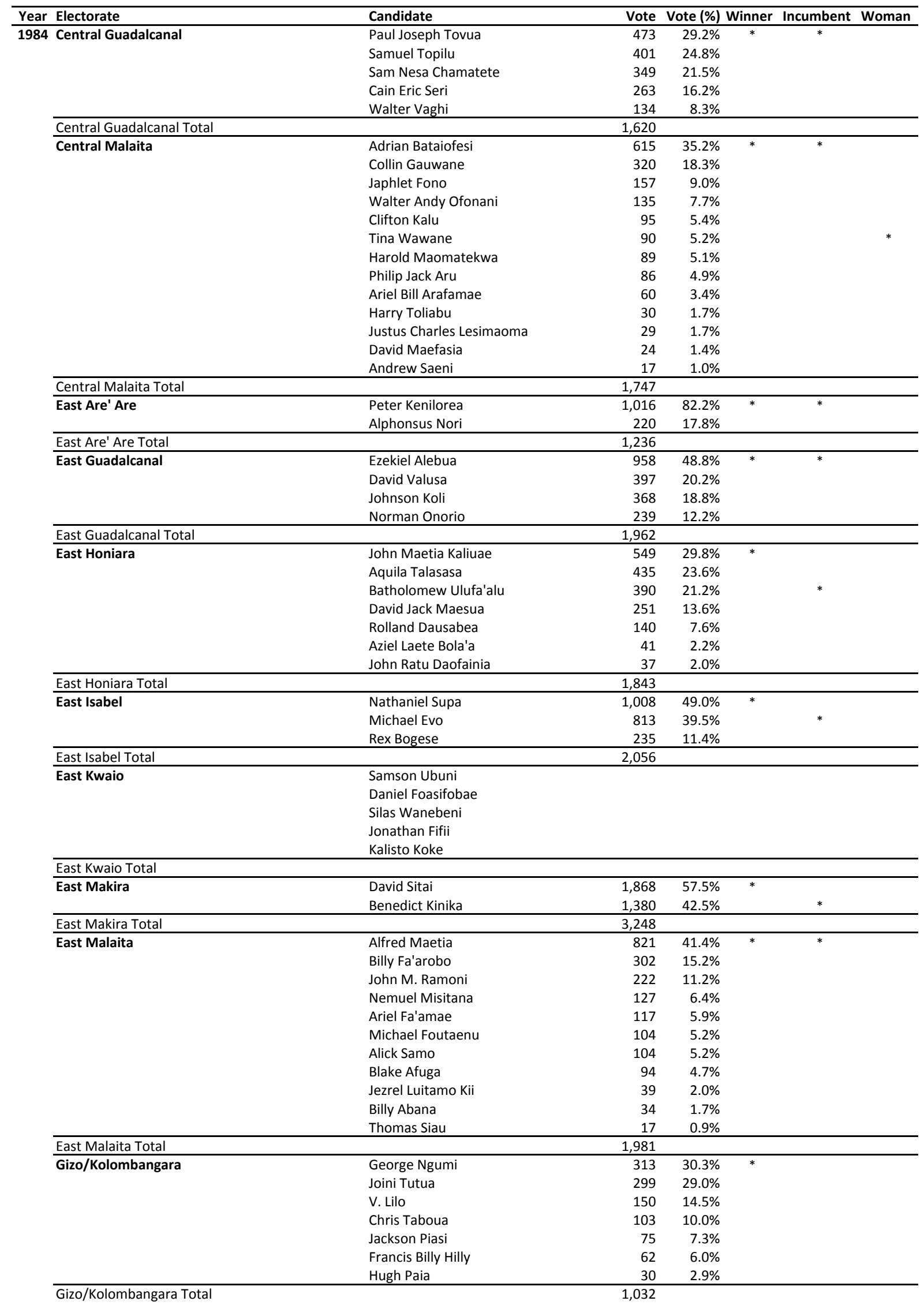


General Election Results

\begin{tabular}{|c|c|c|c|c|c|c|c|}
\hline Year & Electorate & Candidate & Vote & Vote (\%) & Winner & Incumbent & Woman \\
\hline \multirow[t]{18}{*}{$1984 \mathrm{~L}$} & Lau/Mbaelelea & Ben Foukona & 371 & $10.7 \%$ & $*$ & \multirow[t]{18}{*}{ (2) } & \\
\hline & & Paul Maenu'u & 364 & $10.5 \%$ & & & \\
\hline & & Diau Mauga & 351 & $10.1 \%$ & & & \\
\hline & & George Suri Kwanae & 335 & $9.6 \%$ & & & \\
\hline & & Claudio Ganikui & 292 & $8.4 \%$ & & & \\
\hline & & Moses Teteau & 240 & $6.9 \%$ & & & \\
\hline & & Lemuel W. Liobana & 196 & $5.6 \%$ & & & \\
\hline & & Ferania Sale & 184 & $5.3 \%$ & & & \\
\hline & & Bobby Kwaomae & 168 & $4.8 \%$ & & & \\
\hline & & Solomon Beliga Laumae & 160 & $4.6 \%$ & & & \\
\hline & & Selwyn Surimalefo & 155 & $4.5 \%$ & & & \\
\hline & & Texley Fa'asi & 140 & $4.0 \%$ & & & \\
\hline & & Jim Brown Leni & 135 & $3.9 \%$ & & & \\
\hline & & Everest Ega & 129 & $3.7 \%$ & & & \\
\hline & & Saeti Saefafia & 81 & $2.3 \%$ & & & \\
\hline & & Alfred Bouro & 79 & $2.3 \%$ & & & \\
\hline & & Wilfred Ben Kiriau & 69 & $2.0 \%$ & & & \\
\hline & & Jimmy Ngatamae & 25 & $0.7 \%$ & & & \\
\hline & Lau/Mbaelelea Total & & 3,474 & & & & \\
\hline \multirow{5}{*}{\multicolumn{2}{|c|}{ Malaita Outer Islands }} & Abraham Kapei & 216 & $33.8 \%$ & $*$ & \multirow{5}{*}{$*$} & \\
\hline & & Paul Keyaumi & 191 & $29.9 \%$ & & & \\
\hline & & Johnson Kengalu & 163 & $25.5 \%$ & & & \\
\hline & & Mark Etua & 38 & $5.9 \%$ & & & \\
\hline & & Reuben Tenai & 31 & $4.9 \%$ & & & \\
\hline & Malaita Outer Islands Total & & 639 & & & & \\
\hline \multirow{4}{*}{\multicolumn{2}{|c|}{ Marovo }} & Christopher C. Abe & 719 & $38.8 \%$ & * & \multirow{5}{*}{$*$} & \\
\hline & & Snyder Rini & 559 & $30.2 \%$ & & & \\
\hline & & Rodrick Terry Kera & 295 & $15.9 \%$ & & & \\
\hline & & Pulepada Ghemu & 278 & $15.0 \%$ & & & \\
\hline & Marovo Total & & 1,851 & & & & \\
\hline \multirow{7}{*}{\multicolumn{2}{|c|}{ Nggela }} & Robert Bera & 1,022 & $33.1 \%$ & $*$ & & \\
\hline & & Gordon Mara & 903 & $29.2 \%$ & & & \\
\hline & & Henry Raraka Koga & 536 & $17.4 \%$ & & & \\
\hline & & Richard Tinoni & 315 & $10.2 \%$ & & & \\
\hline & & Johnson Soro & 172 & $5.6 \%$ & & & \\
\hline & & Richard Harper & 78 & $2.5 \%$ & & $*$ & \\
\hline & & Ben Tumulima & 62 & $2.0 \%$ & & & \\
\hline & Nggela Total & & 3,088 & & & & \\
\hline & North Choiseul & Allan Qurusu & 904 & $62.8 \%$ & * & * & \\
\hline & & Isaac Koramakolo & 283 & $19.7 \%$ & & & \\
\hline & & Jimmy Pitanapi & 253 & $17.6 \%$ & & & \\
\hline & North Choiseul Total & & 1,440 & & & & \\
\hline & North East Guadalcanal (old) & Daniel Sade & 441 & $32.4 \%$ & * & & \\
\hline & & Waeta Ben & 377 & $27.7 \%$ & & $*$ & \\
\hline & & Nelson Thoa & 239 & $17.6 \%$ & & & \\
\hline & & Billy Tapalia & 124 & $9.1 \%$ & & & \\
\hline & & Reuben Bula & 83 & $6.1 \%$ & & & \\
\hline & & Moses Ghaua & 70 & $5.1 \%$ & & & \\
\hline & & Simon None & 27 & $2.0 \%$ & & & \\
\hline & North East Guadalcanal (old) Total & & 1,361 & & & & \\
\hline & North Guadalcanal & Stephen Paeni & 676 & $31.5 \%$ & $*$ & & \\
\hline & & Alfred Thugea & 531 & $24.7 \%$ & & & \\
\hline & & David Thuguvoda & 361 & $16.8 \%$ & & & \\
\hline & & Samuel Ono & 254 & $11.8 \%$ & & & \\
\hline & & Alfred Maeke & 228 & $10.6 \%$ & & & \\
\hline & & Peter Sesela & 97 & $4.5 \%$ & & & \\
\hline & North Guadalcanal Total & & 2,147 & & & & \\
\hline & North West Malaita & Swanson Cornelius Konofilia & 360 & $22.0 \%$ & * & & \\
\hline & & Bartholomew Leni Olea & 234 & $14.3 \%$ & & $*$ & \\
\hline & & Norman Kwalemanu & 226 & $13.8 \%$ & & & \\
\hline & & Samuel Misitana & 151 & $9.2 \%$ & & & \\
\hline & & Saul Siomagela & 142 & $8.7 \%$ & & & \\
\hline & & Joseph Taega & 141 & $8.6 \%$ & & & \\
\hline & & John Rarangia & 106 & $6.5 \%$ & & & \\
\hline & & James Delamani & 100 & $6.1 \%$ & & & \\
\hline & & Andrew Willis & 72 & $4.4 \%$ & & & \\
\hline & & Leonard Suluala & 49 & $3.0 \%$ & & & \\
\hline & & Felix Laumae & 33 & $2.0 \%$ & & & \\
\hline & & Francis Daukwai & 24 & $1.5 \%$ & & & \\
\hline & North West Malaita Total & & 1,638 & & & & \\
\hline & Ranongga/Simbo & Charlie Panakera & 664 & $47.5 \%$ & * & & \\
\hline & & Peter Beck & 345 & $24.7 \%$ & & & \\
\hline & & Boaz Nagu Eddie & 153 & $11.0 \%$ & & & \\
\hline & & Bruce Ragoso & 147 & $10.5 \%$ & & & \\
\hline & & Patterson Runikera & 88 & $6.3 \%$ & & & \\
\hline & Ranongga/Simbo Total & & 1,397 & & & & \\
\hline
\end{tabular}


General Election Results

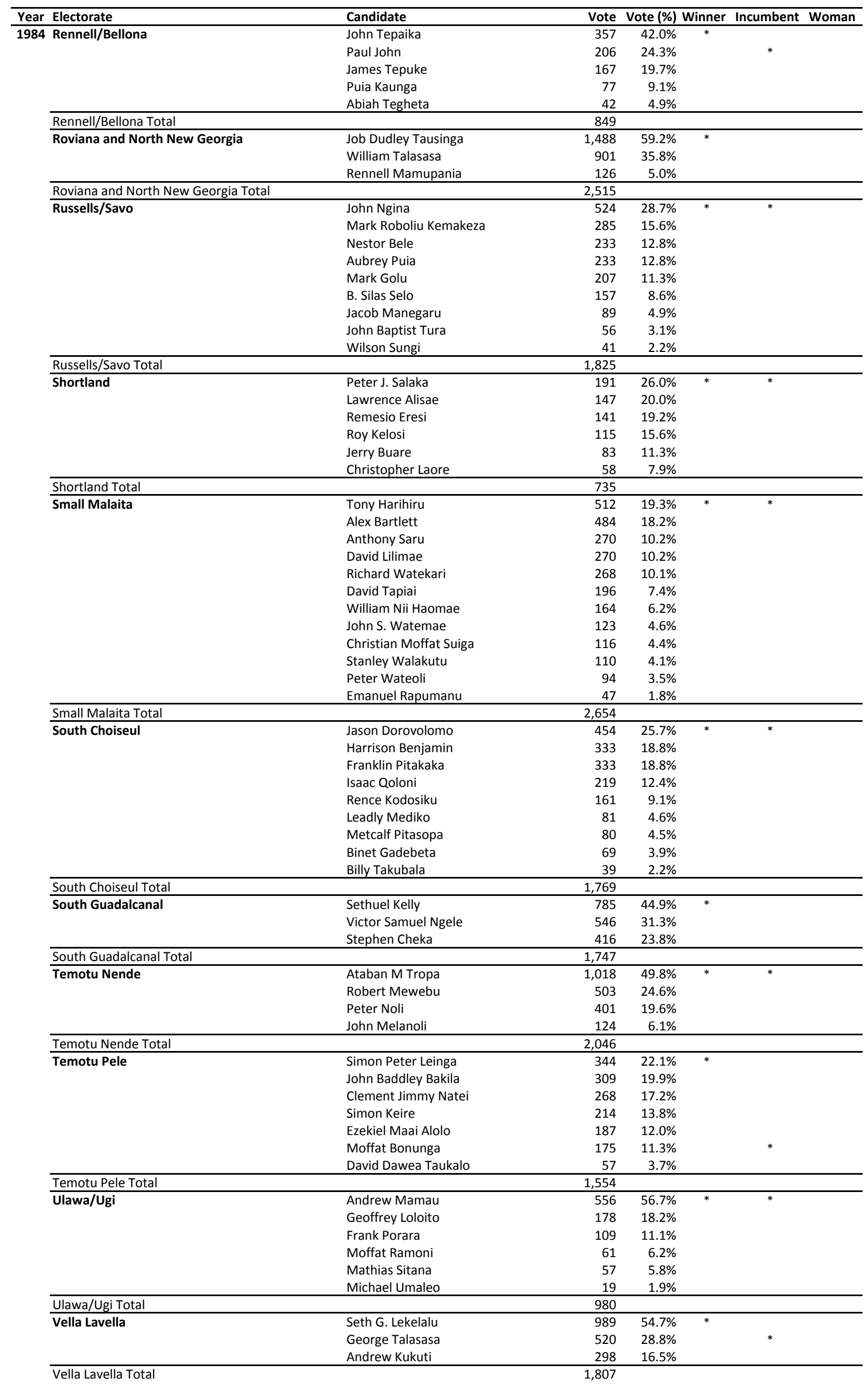


General Election Results

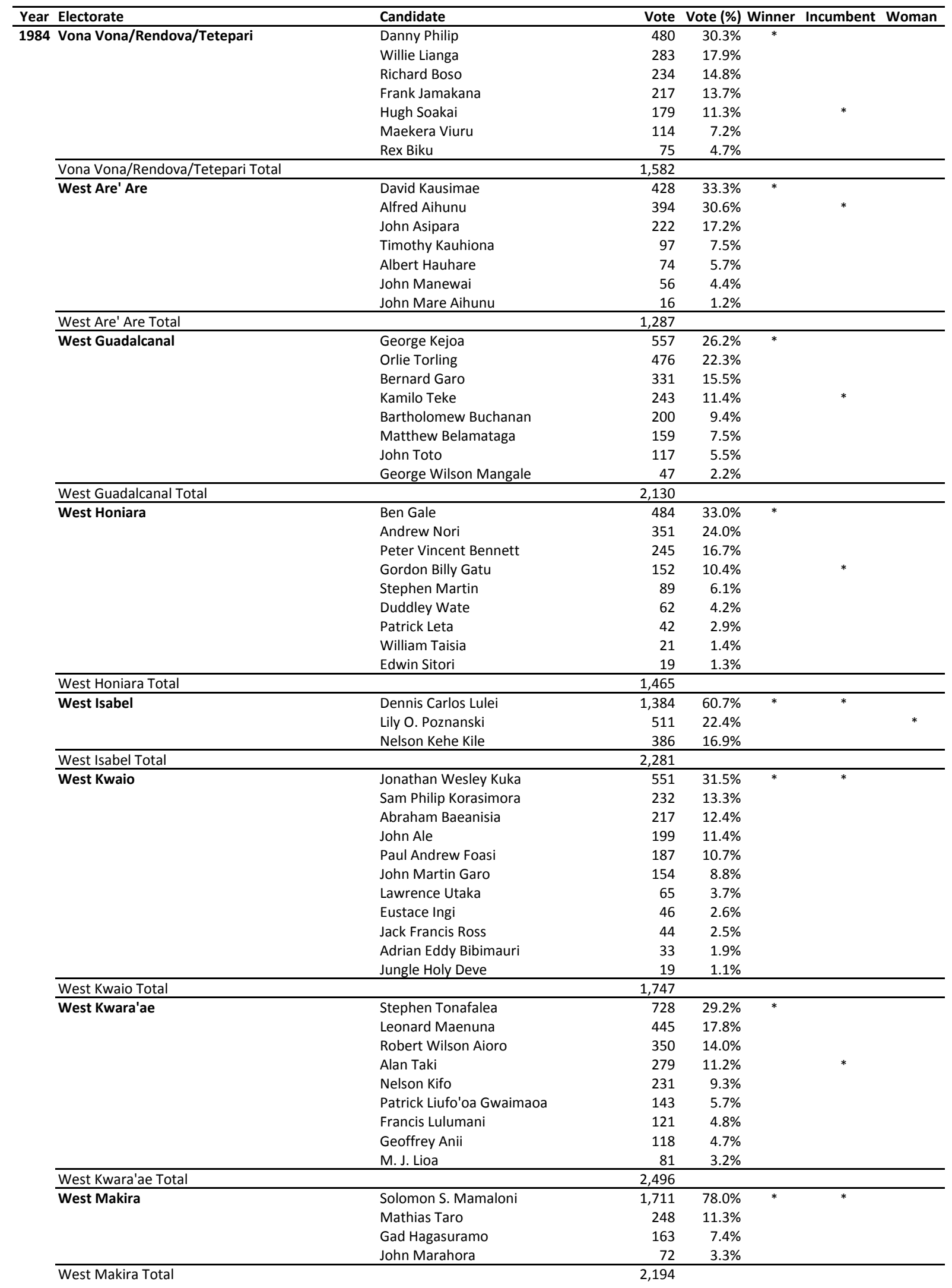




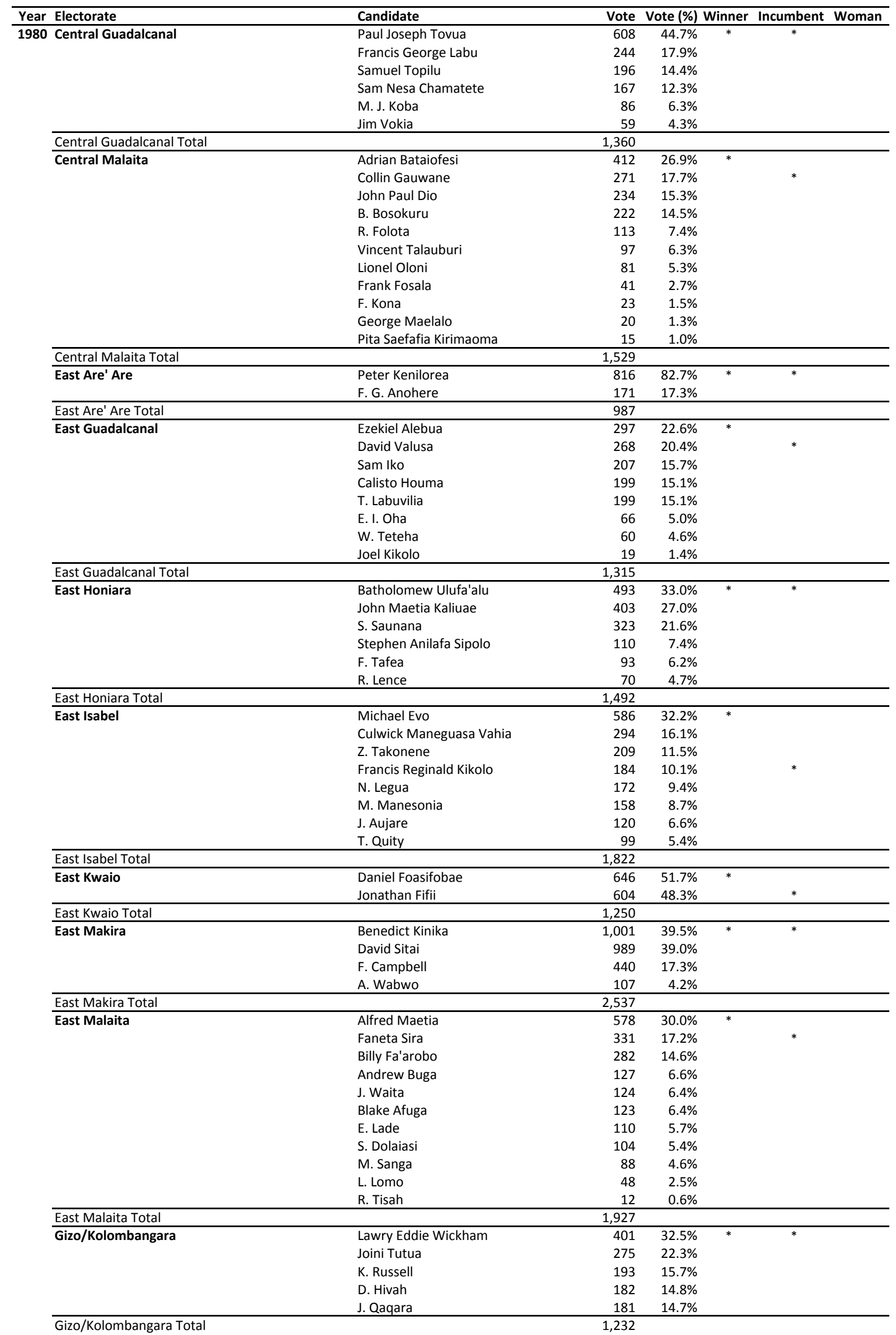




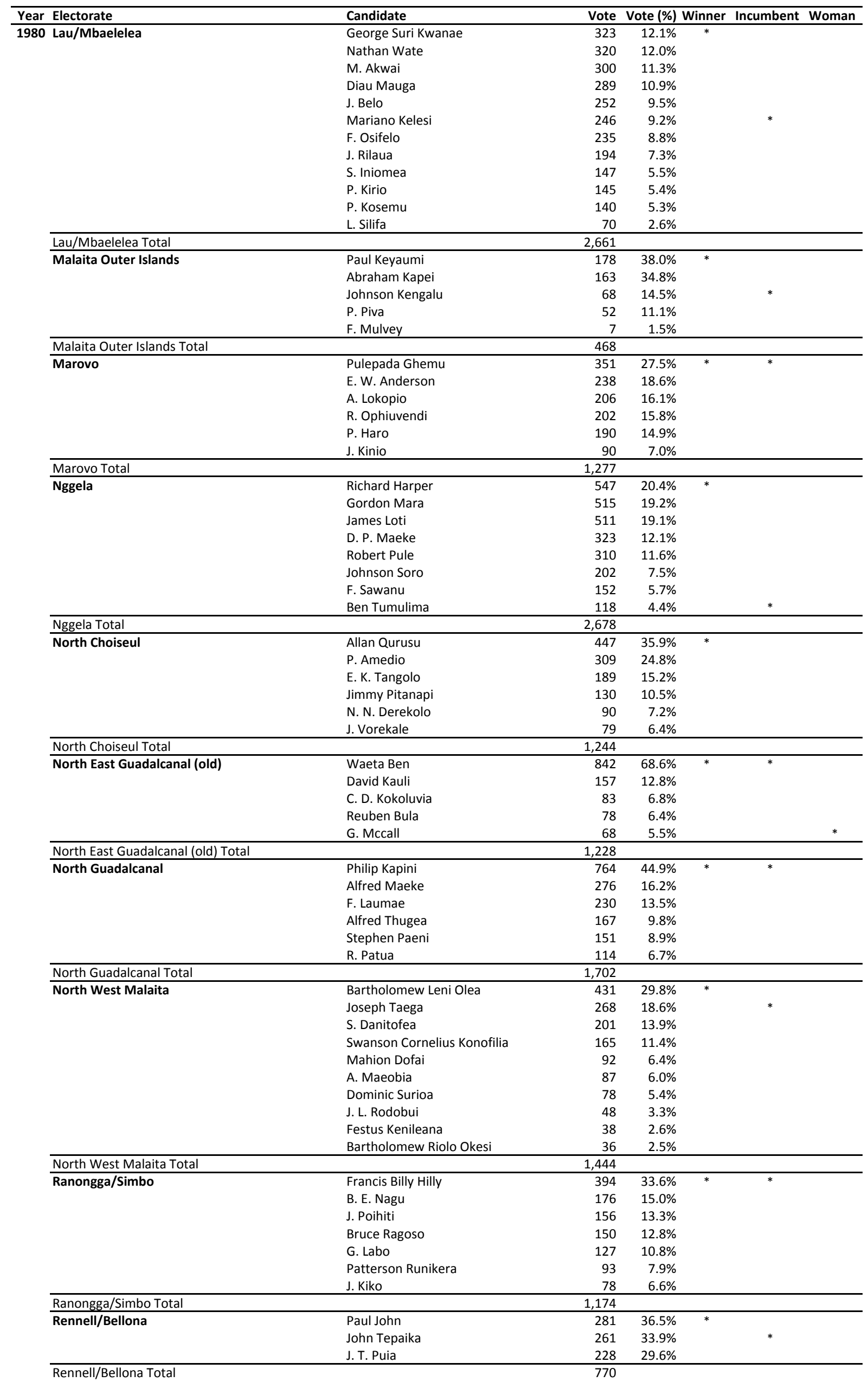




\begin{tabular}{|c|c|c|c|c|c|c|c|}
\hline Year & Electorate & Candidate & Vote & Vote (\%) & Winner & Incumbent & Woman \\
\hline \multirow[t]{13}{*}{1980} & \multirow[t]{5}{*}{ Roviana and North New Georgia } & Geoffrey Opokana Beti & 701 & $46.7 \%$ & \multirow[t]{5}{*}{$*$} & \multirow[t]{5}{*}{$*$} & \\
\hline & & Frank Jamakana & 393 & $26.2 \%$ & & & \\
\hline & & W. Uluilakeba & 240 & $16.0 \%$ & & & \\
\hline & & Luxton Jovere & 90 & $6.0 \%$ & & & \\
\hline & & Alphonse Daga & 76 & $5.1 \%$ & & & \\
\hline & Roviana and North New Georgia Total & & 1,500 & & & & \\
\hline & \multirow[t]{7}{*}{ Russells/Savo } & John Ngina & 395 & $28.6 \%$ & * & \multirow{7}{*}{ * } & \\
\hline & & Peter Manetiva & 335 & $24.2 \%$ & & & \\
\hline & & Mark Vaka & 257 & $18.6 \%$ & & & \\
\hline & & A. Tonezepo & 171 & $12.4 \%$ & & & \\
\hline & & A. Adifaka & 108 & $7.8 \%$ & & & \\
\hline & & S. Timi & 70 & $5.1 \%$ & & & \\
\hline & & G. Tatea & 47 & $3.4 \%$ & & & \\
\hline & Russells/Savo Total & & 1,383 & & & & \\
\hline & \multirow[t]{5}{*}{ Shortland } & Peter J. Salaka & 348 & $54.2 \%$ & * & & \\
\hline & & Roy Kelosi & 110 & $17.1 \%$ & & & \\
\hline & & Remesio Eresi & 103 & $16.0 \%$ & & * & \\
\hline & & R. Kimisi & 50 & $7.8 \%$ & & & \\
\hline & & Edward Kingmele & 31 & $4.8 \%$ & & & \\
\hline & Shortland Total & & 642 & & & & \\
\hline & Small Malaita & Tony Harihiru & 924 & $38.3 \%$ & * & & \\
\hline & & Alex Bartlett & 364 & $15.1 \%$ & & & \\
\hline & & Anthony Saru & 286 & $11.9 \%$ & & & \\
\hline & & Richard Watekari & 205 & $8.5 \%$ & & & \\
\hline & & David Lilimae & 182 & $7.5 \%$ & & & \\
\hline & & Emilio Li'I Ouou & 151 & $6.3 \%$ & & $*$ & \\
\hline & & S. B. Ohanikeni & 123 & $5.1 \%$ & & & \\
\hline & & B. Rilanga & 76 & $3.2 \%$ & & & \\
\hline & & D. L. Uqemane & 51 & $2.1 \%$ & & & \\
\hline & & A. Po'oia & 32 & $1.3 \%$ & & & \\
\hline & & H. Maelasi & 18 & $0.7 \%$ & & & \\
\hline & Small Malaita Total & & 2,412 & & & & \\
\hline & South Choiseul & Jason Dorovolomo & 621 & $45.4 \%$ & * & * & \\
\hline & & Franklin Pitakaka & 318 & $23.3 \%$ & & & \\
\hline & & J. Gaqurae & 268 & $19.6 \%$ & & & \\
\hline & & M. Pitakaka & 160 & $11.7 \%$ & & & \\
\hline & South Choiseul Total & & 1,367 & & & & \\
\hline & South Guadalcanal & George Wilson Mangale & 413 & $26.6 \%$ & * & & \\
\hline & & D. Manea & 390 & $25.1 \%$ & & & \\
\hline & & A. Manakako & 267 & $17.2 \%$ & & & \\
\hline & & Victor Alikivara & 243 & $15.7 \%$ & & & \\
\hline & & S. Sese & 182 & $11.7 \%$ & & & \\
\hline & & P. Manegavai & 56 & $3.6 \%$ & & & \\
\hline & South Guadalcanal Total & & 1,551 & & & & \\
\hline & Temotu Nende & Ataban M Tropa & 499 & $32.5 \%$ & * & & \\
\hline & & Robert Mewebu & 359 & $23.4 \%$ & & & \\
\hline & & Samuel Tensing Leo & 292 & $19.0 \%$ & & & \\
\hline & & John Melanoli & 218 & $14.2 \%$ & & $*$ & \\
\hline & & J. Mekabu & 168 & $10.9 \%$ & & & \\
\hline & Temotu Nende Total & & 1,536 & & & & \\
\hline & Temotu Pele & Moffat Bonunga & 567 & $37.3 \%$ & * & $*$ & \\
\hline & & Matthew Leuba & 268 & $17.6 \%$ & & & \\
\hline & & John Mark Ma'ake & 252 & $16.6 \%$ & & & \\
\hline & & B. Bonie & 228 & $15.0 \%$ & & & \\
\hline & & Santas Paikai & 207 & $13.6 \%$ & & & \\
\hline & Temotu Pele Total & & 1,522 & & & & \\
\hline & Ulawa/Ugi & Andrew Mamau & 542 & $62.2 \%$ & * & & \\
\hline & & Daniel Ho'ota & 282 & $32.3 \%$ & & $*$ & \\
\hline & & B. Tapo'oa & 48 & $5.5 \%$ & & & \\
\hline & Ulawa/Ugi Total & & 872 & & & & \\
\hline & Vella Lavella & George Talasasa & 275 & $17.0 \%$ & * & & \\
\hline & & S. Matluri & 274 & $17.0 \%$ & & & \\
\hline & & C. Dorauvo & 253 & $15.7 \%$ & & & \\
\hline & & Andrew Kukuti & 236 & $14.6 \%$ & & * & \\
\hline & & Seth G. Lekelalu & 222 & $13.7 \%$ & & & \\
\hline & & S. Rausu & 181 & $11.2 \%$ & & & \\
\hline & & C. Piraka & 174 & $10.8 \%$ & & & \\
\hline & Vella Lavella Total & & 1,615 & & & & \\
\hline & Vona Vona/Rendova/Tetepari & Hugh Soakai & 379 & $27.2 \%$ & * & & \\
\hline & & John Talasasa & 272 & $19.5 \%$ & & $*$ & \\
\hline & & J. D. Mare & 247 & $17.7 \%$ & & & \\
\hline & & George Pina Lilo & 198 & $14.2 \%$ & & & \\
\hline & & Patrick Paia & 110 & $7.9 \%$ & & & \\
\hline & & Darcy Everett Lilo & 104 & $7.5 \%$ & & & \\
\hline & & B. Gadepeta & 45 & $3.2 \%$ & & & \\
\hline & & J. I. Sakiri & 38 & $2.7 \%$ & & & \\
\hline
\end{tabular}


General Election Results

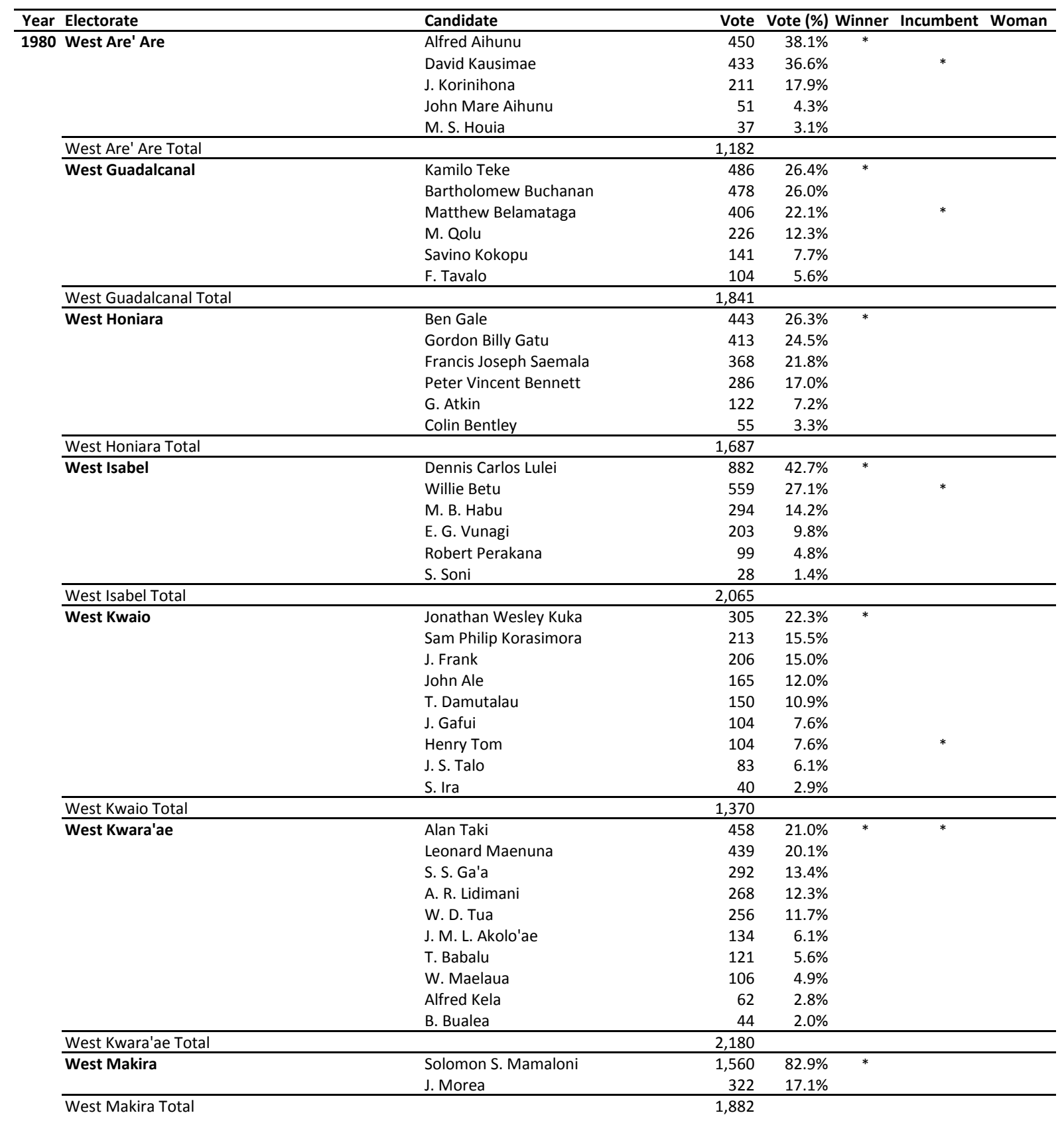




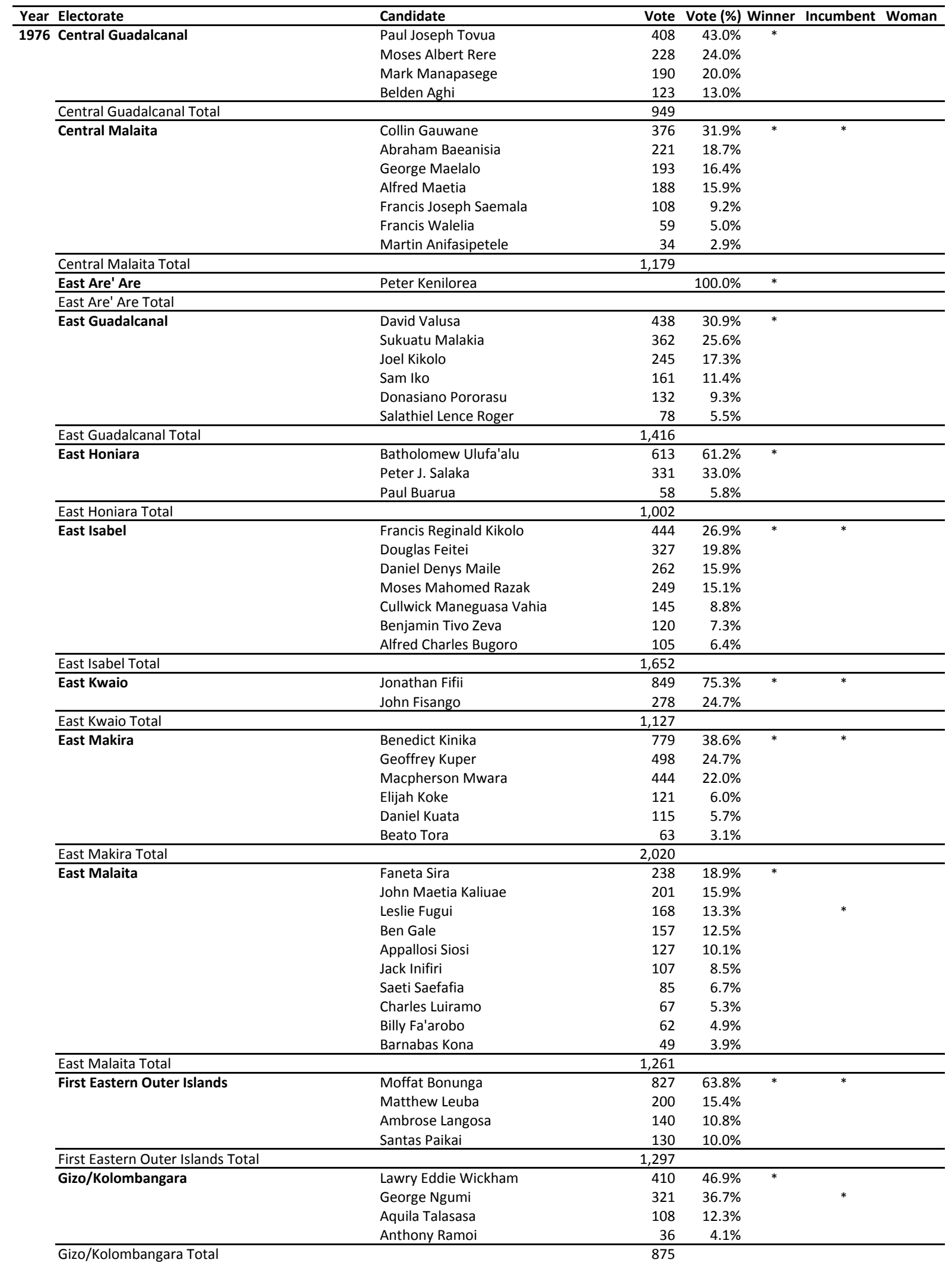




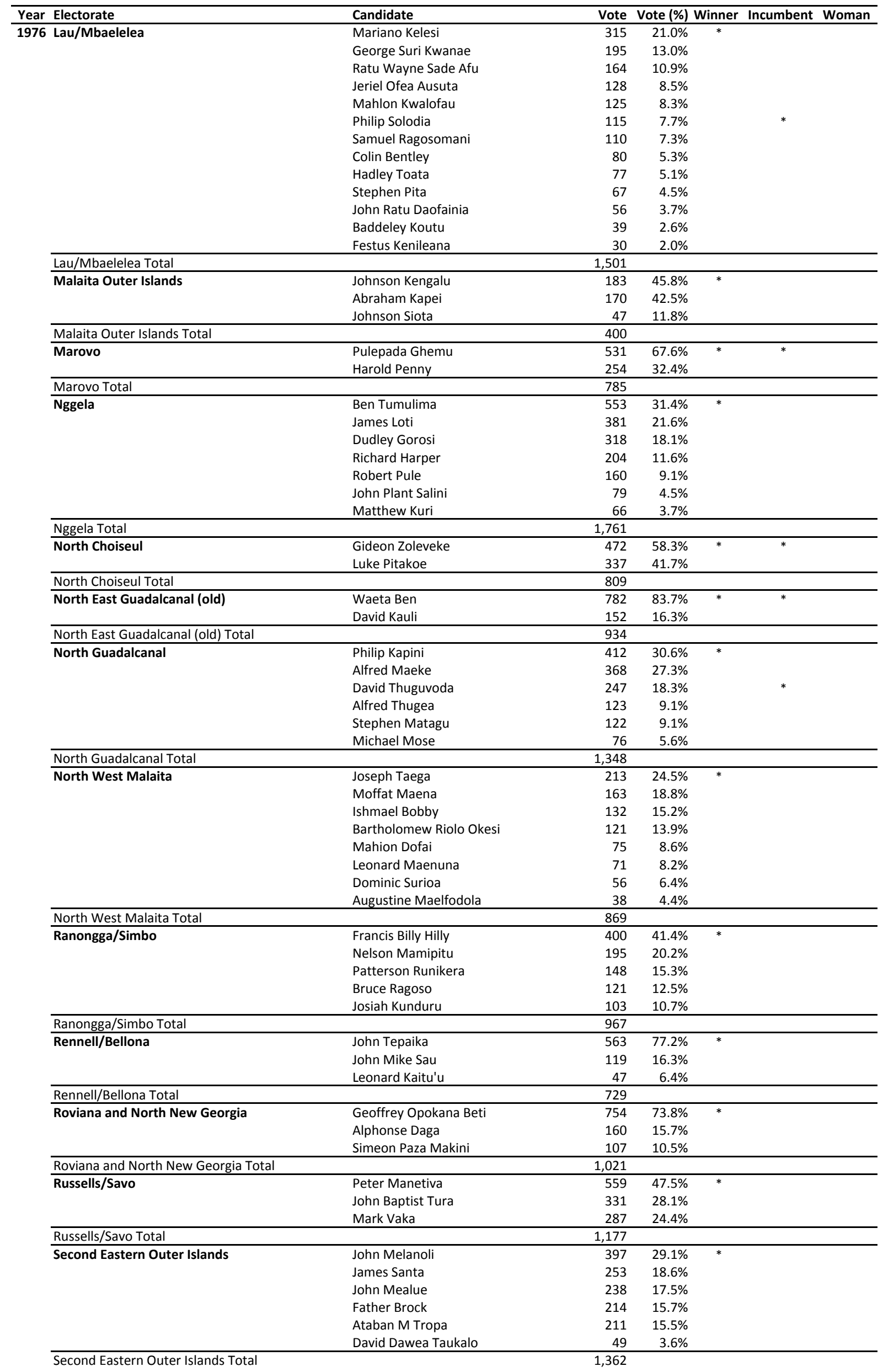


General Election Results

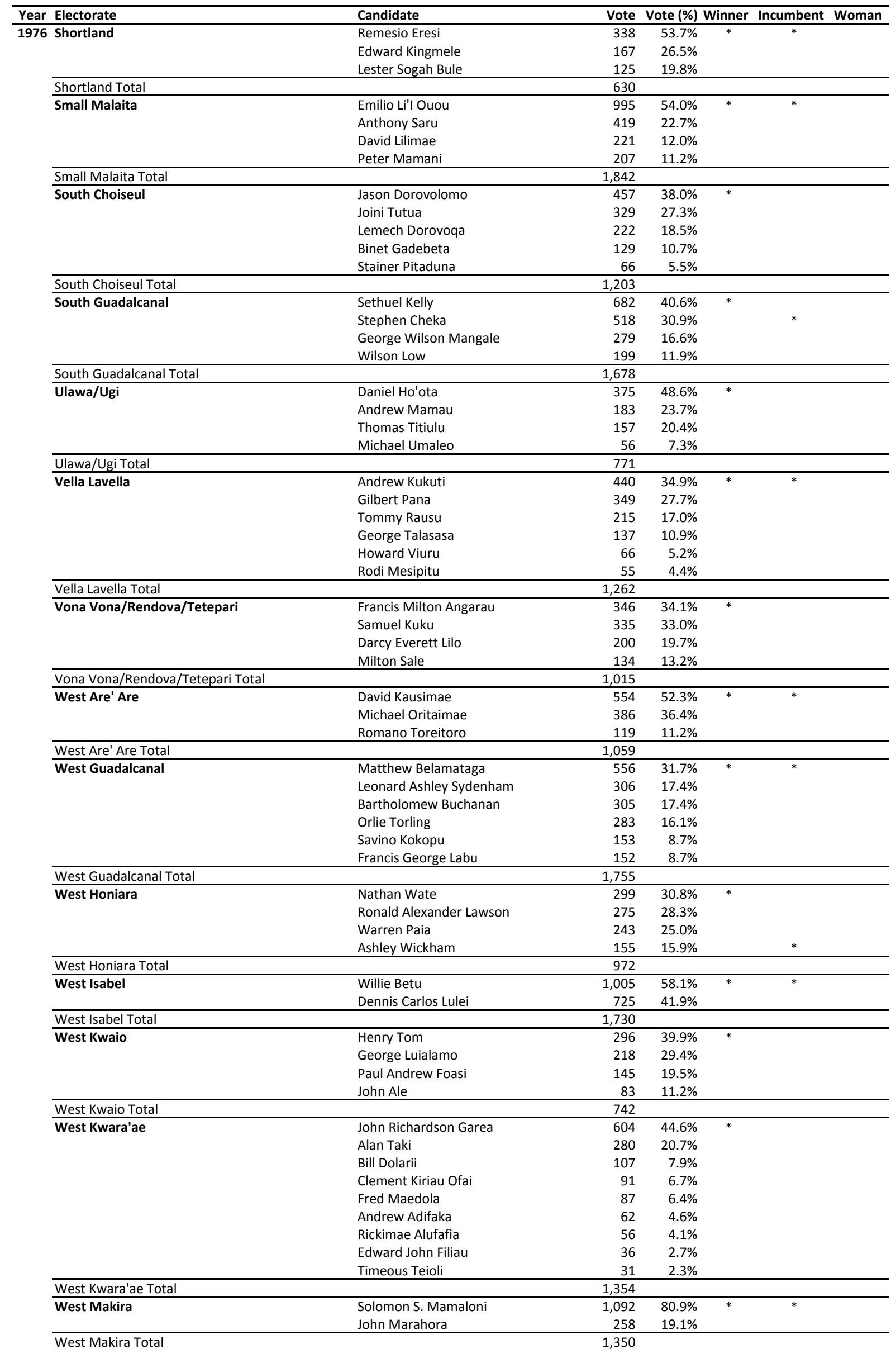




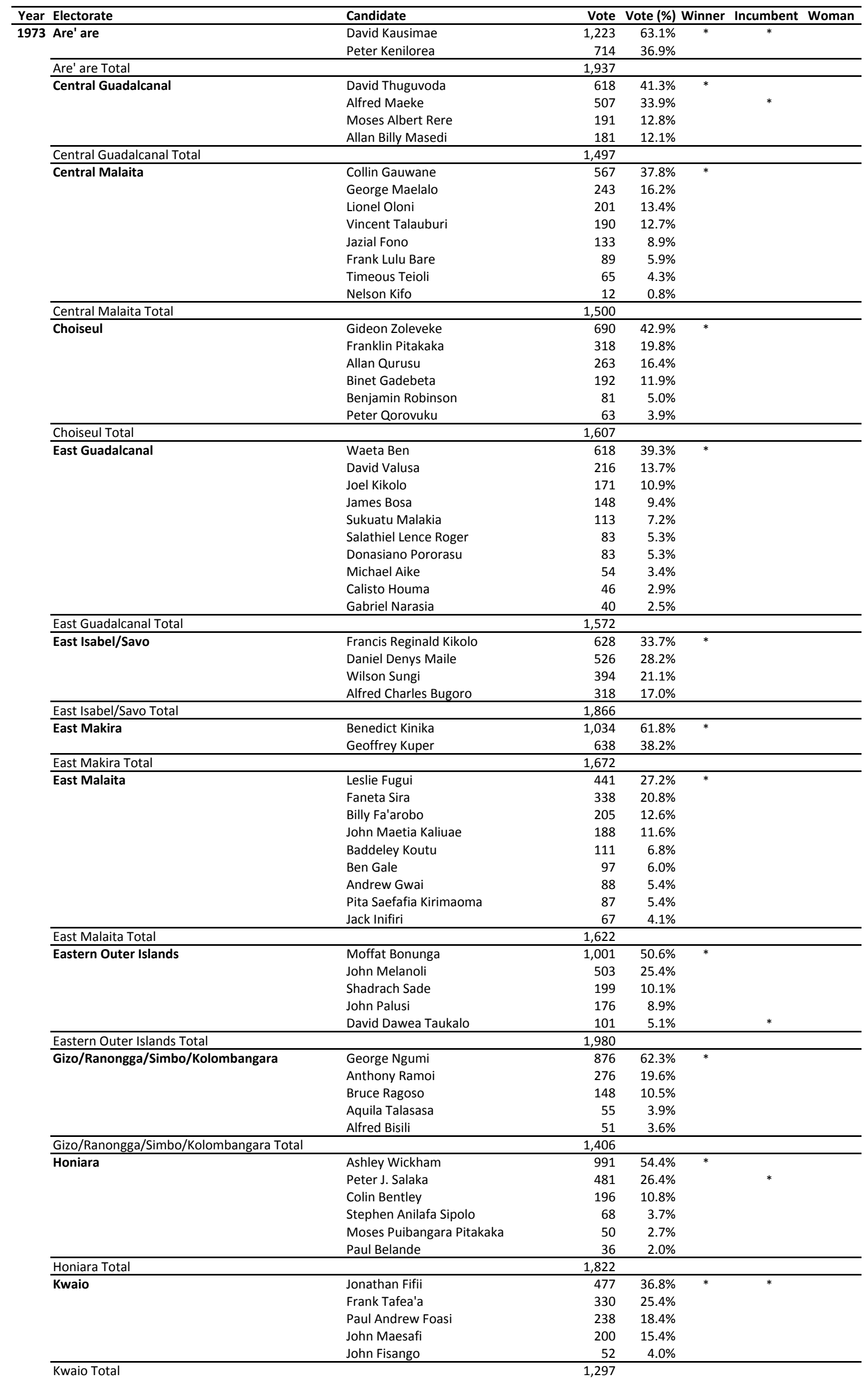


General Election Results

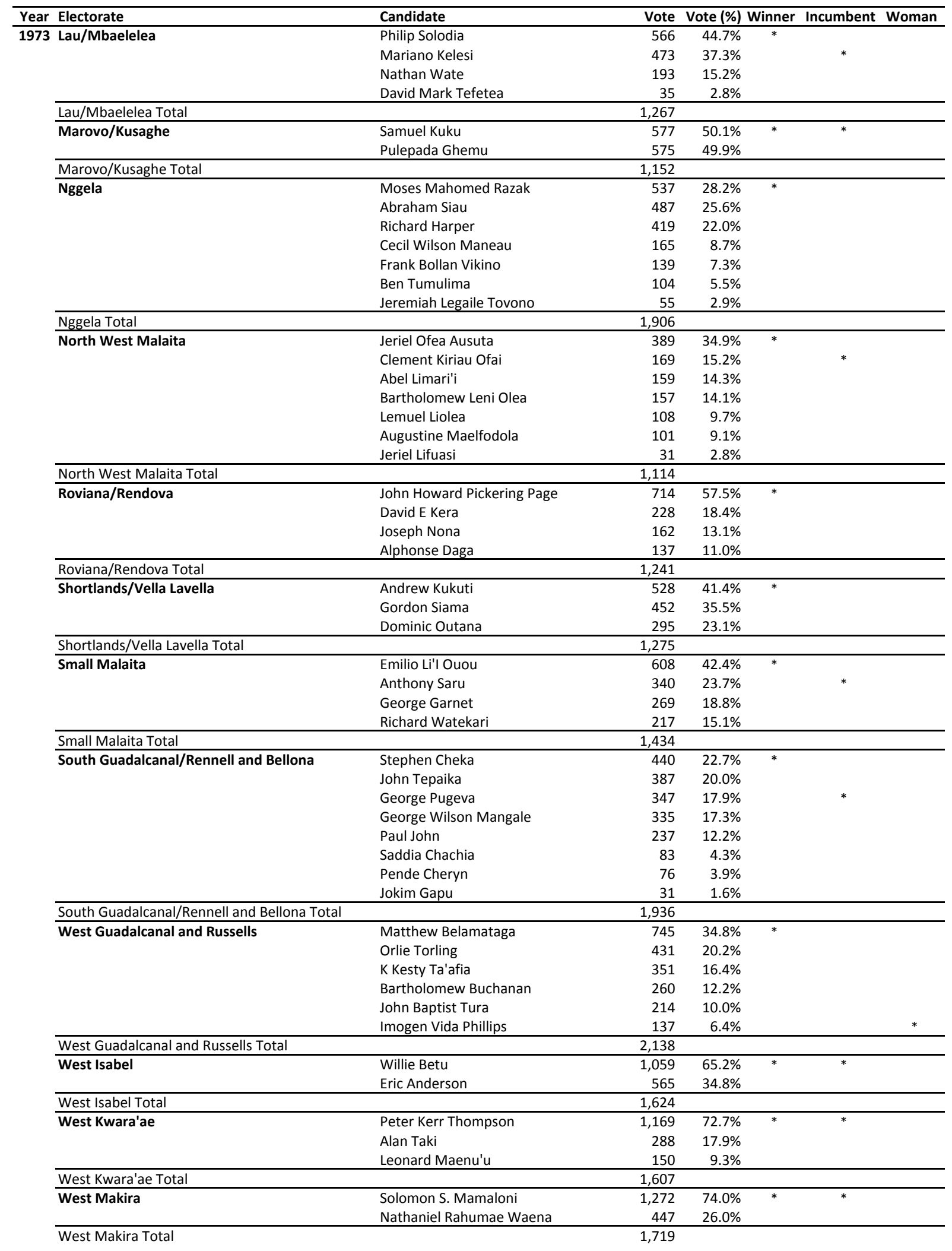


General Election Results

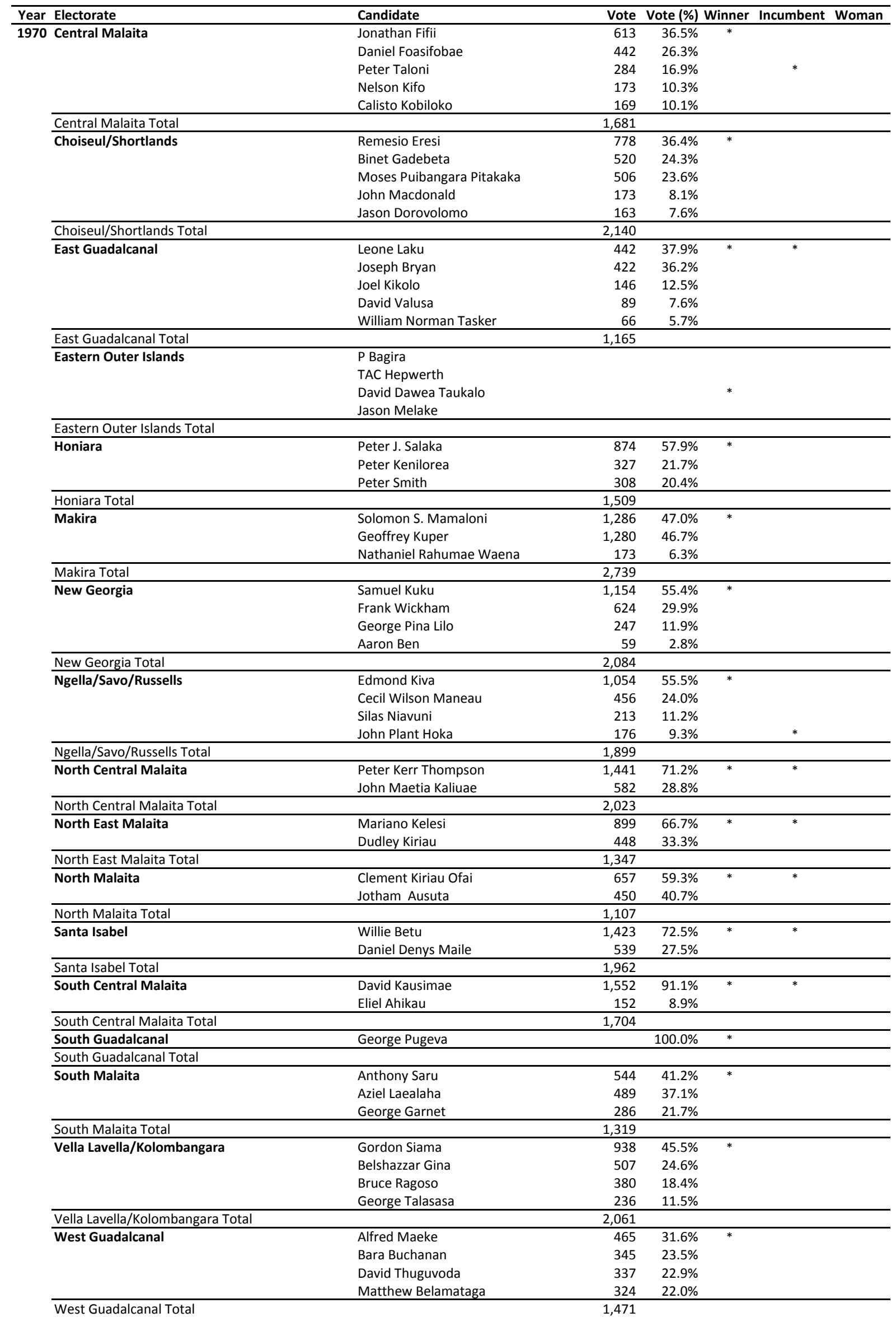


General Election Results

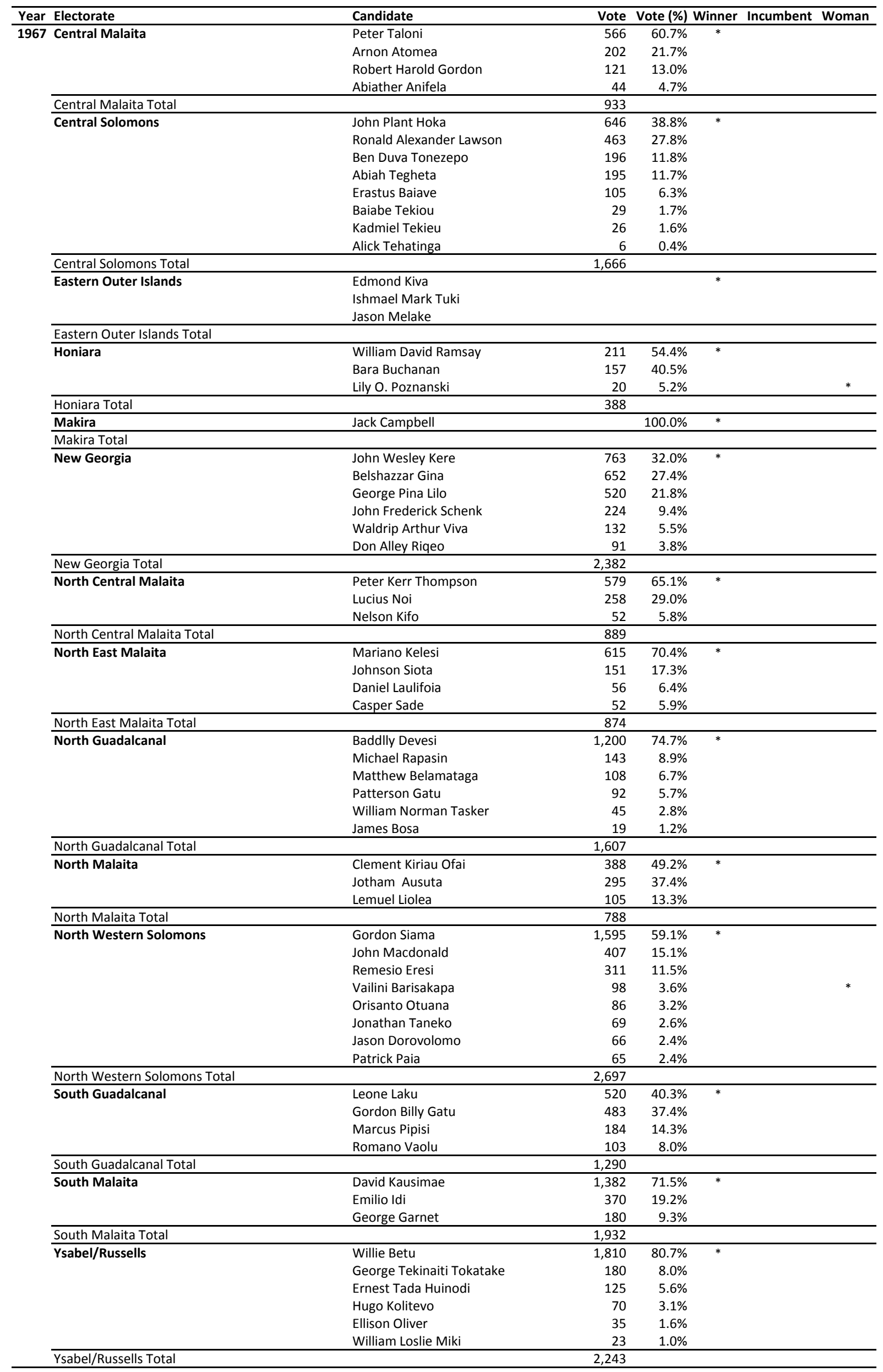




$$
\begin{aligned}
& \text { By-Election Results } \\
& \text { 1967-2013 }
\end{aligned}
$$




\section{Data Notes on By-Elections}

Data are from the following sources:

2013-2008 directly from the Electoral Commission or from the Solomon Islands Gazette 2004 the Solomon Islands Gazette

2003 the Solomon Islands Gazette

1994 the Solomon Islands Gazette

1992 the Solomon Islands Gazette

1990 the Solomon Islands Gazette

1985 the Solomon Star Newspaper

1974 the Solomon Islands Gazette

Refer to general election data notes for other comments 


\begin{tabular}{|c|c|c|c|c|c|c|c|}
\hline Year & Electorate & Candidate & Vote & Vote (\%) & Winner & Incumbent & Woman \\
\hline \multirow[t]{12}{*}{2013} & Nggela & Johnley T. Hatimoana & 2,193 & $28.2 \%$ & $*$ & & \\
\hline & & Bartholomew Parapolo & 1,033 & $13.3 \%$ & & & \\
\hline & & Henry Zimbo & 967 & $12.4 \%$ & & & \\
\hline & & Christian Salini & 761 & $9.8 \%$ & & & \\
\hline & & Cecil Loti & 689 & $8.8 \%$ & & & \\
\hline & & David Harper & 653 & $8.4 \%$ & & & \\
\hline & & Samuel Balea & 638 & $8.2 \%$ & & & \\
\hline & & Janet Baraisi Kemakeza & 531 & $6.8 \%$ & & & $*$ \\
\hline & & Cathy Vuni Roy & 265 & $3.4 \%$ & & & $*$ \\
\hline & & Rejected Votes & 48 & $0.6 \%$ & & & \\
\hline & & Henry Luito'o Fa'arodo & 10 & $0.1 \%$ & & & \\
\hline & Nggela Total & & 7,788 & & & & \\
\hline \multirow[t]{17}{*}{2012} & East Are' Are & Andrew Manepora'a & 2,157 & $54.0 \%$ & $*$ & & \\
\hline & & Aliki Tokii Ha'apio & 1,228 & $30.7 \%$ & & & \\
\hline & & Peter Kenilorea & 460 & $11.5 \%$ & & & \\
\hline & & Claudius Horiwapu & 152 & $3.8 \%$ & & & \\
\hline & East Are' Are Total & & 3,997 & & & & \\
\hline & North Malaita & Vika Lusibaea & 2,802 & $49.2 \%$ & $*$ & & $*$ \\
\hline & & Fredrick Kwanairara & 901 & $15.8 \%$ & & & \\
\hline & & Senley Levi Filualea & 675 & $11.9 \%$ & & & \\
\hline & & Peter Fairamoa & 503 & $8.8 \%$ & & & \\
\hline & & Daniel R Faafunua & 269 & $4.7 \%$ & & & \\
\hline & & Joel Moffat Konofilia & 248 & $4.4 \%$ & & & \\
\hline & & Wilfred Baetalua & 189 & $3.3 \%$ & & & \\
\hline & & Felix Maeli Abuofa & 51 & $0.9 \%$ & & & \\
\hline & & Rejected Votes & 28 & $0.5 \%$ & & & \\
\hline & & Sensie George & 23 & $0.4 \%$ & & & \\
\hline & & Ben Fruits O'Bana & 4 & $0.1 \%$ & & & \\
\hline & North Malaita Total & & 5,693 & & & & \\
\hline \multirow[t]{25}{*}{2011} & Baegu/Asifola & David Tome & 1,366 & $21.3 \%$ & $*$ & & \\
\hline & & Henry Ologa Olobeni & 1,117 & $17.4 \%$ & & & \\
\hline & & Tagini Makario & 1,048 & $16.4 \%$ & & & \\
\hline & & Siau Mana & 855 & $13.3 \%$ & & & \\
\hline & & Martin Saefafia & 521 & $8.1 \%$ & & & \\
\hline & & Edgar Maoma Kaua & 512 & $8.0 \%$ & & & \\
\hline & & Duddley Wate & 411 & $6.4 \%$ & & & \\
\hline & & Robert Dolaiasi Kaua & 177 & $2.8 \%$ & & & \\
\hline & & James Kili & 177 & $2.8 \%$ & & & \\
\hline & & Frederick Waiti & 118 & $1.8 \%$ & & & \\
\hline & & John Maga Falasi & 34 & $0.5 \%$ & & & \\
\hline & & Timothy Amao & 29 & $0.5 \%$ & & & \\
\hline & & Rejected Votes & 28 & $0.4 \%$ & & & \\
\hline & & Duddley lasuri & 16 & $0.2 \%$ & & & \\
\hline & Baegu/Asifola Total & & 6,409 & & & & \\
\hline & Shortland & Christopher Laore & 1,353 & $61.5 \%$ & $*$ & & \\
\hline & & Augustine Taneko & 731 & $33.2 \%$ & & & \\
\hline & & Pellion Buare & 111 & $5.0 \%$ & & & \\
\hline & & Rejected Votes & 4 & $0.2 \%$ & & & \\
\hline & & Joseph Isang Pitu & 1 & $0.0 \%$ & & & \\
\hline & Shortland Total & & 2,200 & & & & \\
\hline & Central Guadalcanal & Peter Shanel Agovaka & 2,089 & $58.0 \%$ & $*$ & $*$ & \\
\hline & & Walton Naezol & 1,291 & $35.9 \%$ & & & \\
\hline & & Elvish Kekegolo & 170 & $4.7 \%$ & & & \\
\hline & & Rejected Votes & 51 & $1.4 \%$ & & & \\
\hline
\end{tabular}




\begin{tabular}{|c|c|c|c|c|c|c|c|}
\hline Year & Electorate & Candidate & Vote & Vote (\%) & Winner & Incumbent & Woman \\
\hline \multirow[t]{10}{*}{2009} & Russells/Savo & Allan Kemakeza & 1,654 & $40.6 \%$ & $*$ & $*$ & \\
\hline & & Reginald Hill Kokili & 957 & $23.5 \%$ & & & \\
\hline & & Henry Zimbo & 399 & $9.8 \%$ & & & \\
\hline & & Charles Mcclean & 364 & $8.9 \%$ & & & \\
\hline & & Donald Vakitaina & 312 & $7.7 \%$ & & & \\
\hline & & Rejected Votes & 154 & $3.8 \%$ & & & \\
\hline & & Francis Moah & 145 & $3.6 \%$ & & & \\
\hline & & Simone Geatavem Lifa & 71 & $1.7 \%$ & & & \\
\hline & & Eddy Grant Suku & 19 & $0.5 \%$ & & & \\
\hline & Russells/Savo Total & & 4,075 & & & & \\
\hline \multirow[t]{51}{*}{2008} & Aoke/Langalanga & Mathew Cooper Wale & 1,608 & $29.9 \%$ & * & & \\
\hline & & Billy A. Manu & 1,022 & $19.0 \%$ & & & \\
\hline & & David Faradatolo & 937 & $17.4 \%$ & & & \\
\hline & & Hellen Osi Huniehu & 672 & $12.5 \%$ & & & $*$ \\
\hline & & Billy Gizo Saenamua & 454 & $8.4 \%$ & & & \\
\hline & & Peter Clyde Mamisau & 311 & $5.8 \%$ & & & \\
\hline & & Abraham Willie Waleualo & 214 & $4.0 \%$ & & & \\
\hline & & Meshach Maebiru Maetoloa & 63 & $1.2 \%$ & & & \\
\hline & & Robert Wales Feraltelia & 51 & $0.9 \%$ & & & \\
\hline & & Rejected Votes & 40 & $0.7 \%$ & & & \\
\hline & & Robert Henry Alufurai & 11 & $0.2 \%$ & & & \\
\hline & Aoke/Langalanga Total & & 5,383 & & & & \\
\hline & East Honiara & Milikada Miller Silas & 3,435 & $32.4 \%$ & $*$ & & \\
\hline & & George Mamimu & 1,071 & $10.1 \%$ & & & \\
\hline & & Edward Jacob Ronia & 973 & $9.2 \%$ & & & \\
\hline & & Tagini Makario & 728 & $6.9 \%$ & & & \\
\hline & & Simeon Bouro & 699 & $6.6 \%$ & & & \\
\hline & & Jack Donga & 626 & $5.9 \%$ & & & \\
\hline & & Alfred Solomon Sasako & 484 & $4.6 \%$ & & & \\
\hline & & Rejected Votes & 339 & $3.2 \%$ & & & \\
\hline & & Robert Gerea & 337 & $3.2 \%$ & & & \\
\hline & & Alfred Maetia & 325 & $3.1 \%$ & & & \\
\hline & & Leslie Winston Kakai & 320 & $3.0 \%$ & & & \\
\hline & & Timothy Omani & 211 & $2.0 \%$ & & & \\
\hline & & Andrew Kuvu & 174 & $1.6 \%$ & & & \\
\hline & & Delmah Lavina Nori & 126 & $1.2 \%$ & & & $*$ \\
\hline & & Peterson Boso & 99 & $0.9 \%$ & & & \\
\hline & & Yukio Sato & 93 & $0.9 \%$ & & & \\
\hline & & Joseph Baetolingia & 87 & $0.8 \%$ & & & \\
\hline & & Moses Ramo & 71 & $0.7 \%$ & & & \\
\hline & & Charles Aiwosuga Cheka'a & 70 & $0.7 \%$ & & & \\
\hline & & John Ashley & 51 & $0.5 \%$ & & & \\
\hline & & Ramon Quitales & 48 & $0.5 \%$ & & & \\
\hline & & Ellison Ryan Sade & 46 & $0.4 \%$ & & & \\
\hline & & Kerry Wate & 45 & $0.4 \%$ & & & \\
\hline & & Damien James Teobasi & 42 & $0.4 \%$ & & & \\
\hline & & David Dausabea & 39 & $0.4 \%$ & & & \\
\hline & & Collin Bentley & 31 & $0.3 \%$ & & & \\
\hline & & Wilfred Bello Faari & 27 & $0.3 \%$ & & & \\
\hline & East Honiara Total & & 10,597 & & & & \\
\hline & East Malaita & Manasseh Maelanga & 1,106 & $24.1 \%$ & $*$ & & \\
\hline & & David Toifai Misitomu & 748 & $16.3 \%$ & & & \\
\hline & & Taeasi Sanga & 678 & $14.8 \%$ & & & $*$ \\
\hline & & Alfred Maetia & 642 & $14.0 \%$ & & & \\
\hline & & Chris Maebiru & 346 & $7.5 \%$ & & & \\
\hline & & Tony Maega'asia & 260 & $5.7 \%$ & & & \\
\hline & & Billy Fa'arobo & 218 & $4.7 \%$ & & & \\
\hline & & Elwyn Maetia Rea & 216 & $4.7 \%$ & & & \\
\hline & & David Ganifiri & 199 & $4.3 \%$ & & & \\
\hline & & David Mani Manusau & 155 & $3.4 \%$ & & & \\
\hline & & Wilfred Bello Faari & 25 & $0.5 \%$ & & & \\
\hline
\end{tabular}




\begin{tabular}{|c|c|c|c|c|c|c|c|}
\hline Year & Electorate & Candidate & Vote & Vote (\%) & Winner & Incumbent & Woman \\
\hline \multirow[t]{19}{*}{2008} & Lau/Mbaelelea & Walter Folotalu & 1,092 & $11.8 \%$ & $*$ & & \\
\hline & & Charles Ferania Sale & 933 & $10.1 \%$ & & & \\
\hline & & Judson Lee Leafasia & 839 & $9.1 \%$ & & & \\
\hline & & Toata Molea & 802 & $8.7 \%$ & & & \\
\hline & & Eric George & 782 & $8.5 \%$ & & & \\
\hline & & Paul Maenu'u & 756 & $8.2 \%$ & & & \\
\hline & & Francis Kairi & 685 & $7.4 \%$ & & & \\
\hline & & John Meke & 640 & $6.9 \%$ & & & \\
\hline & & William Ramo & 583 & $6.3 \%$ & & & \\
\hline & & Francis Maaka & 523 & $5.7 \%$ & & & \\
\hline & & Allan Arofoa & 416 & $4.5 \%$ & & & \\
\hline & & Kelesi Robu & 333 & $3.6 \%$ & & & \\
\hline & & Rejected Votes & 292 & $3.2 \%$ & & & \\
\hline & & Robert Mark & 219 & $2.4 \%$ & & & \\
\hline & & Ronald Unga & 150 & $1.6 \%$ & & & \\
\hline & & Philip Jionesi & 133 & $1.4 \%$ & & & \\
\hline & & Ben Foukona & 34 & $0.4 \%$ & & & \\
\hline & & Luke Tome & 12 & $0.1 \%$ & & & \\
\hline & Lau/Mbaelelea Total & & 9,224 & & & & \\
\hline \multirow[t]{15}{*}{2004} & North Malaita & Daniel E. Kwanairara & 1,741 & $34.5 \%$ & $*$ & & \\
\hline & & Michael Maeliau & 1,425 & $28.3 \%$ & & & \\
\hline & & Leliana D Firisua & 617 & $12.2 \%$ & & & \\
\hline & & George Walenenea & 525 & $10.4 \%$ & & & \\
\hline & & George Mamimu & 488 & $9.7 \%$ & & & \\
\hline & & Peter Satu & 247 & $4.9 \%$ & & & \\
\hline & North Malaita Total & & 5,043 & & & & \\
\hline & Ulawa/Ugi & James Tora & 614 & $29.1 \%$ & * & & \\
\hline & & Andrew Mamau & 416 & $19.7 \%$ & & & \\
\hline & & Meffrey Awao & 269 & $12.8 \%$ & & & \\
\hline & & Moffat Marita & 257 & $12.2 \%$ & & & \\
\hline & & Rolland Waenaouou Titiulu & 223 & $10.6 \%$ & & & \\
\hline & & Noel Mamau & 221 & $10.5 \%$ & & & \\
\hline & & Michael Ben Walahoula & 109 & $5.2 \%$ & & & \\
\hline & Ulawa/Ugi Total & & 2,109 & & & & \\
\hline \multirow[t]{7}{*}{2003} & South Guadalcanal & Victor Totu & 728 & $30.1 \%$ & * & & \\
\hline & & Rollen Seleso & 587 & $24.3 \%$ & & & \\
\hline & & Sethuel Kelly & 454 & $18.8 \%$ & & & \\
\hline & & Stephen Noel Ngele & 335 & $13.9 \%$ & & & \\
\hline & & Joshua Karichi & 248 & $10.3 \%$ & & & \\
\hline & & Shadrack Sese & 66 & $2.7 \%$ & & & \\
\hline & South Guadalcanal Total & & 2,418 & & & & \\
\hline \multirow[t]{5}{*}{1994} & East Honiara & John Maetia Kaliuae & 1,558 & $42.3 \%$ & $*$ & & \\
\hline & & Charles Dausabea & 1,401 & $38.1 \%$ & & $*$ & \\
\hline & & Christina Garo & 419 & $11.4 \%$ & & & $*$ \\
\hline & & Ronald Kuba Ziru & 302 & $8.2 \%$ & & & \\
\hline & East Honiara Total & & 3,680 & & & & \\
\hline \multirow[t]{6}{*}{1992} & East Are' Are & Edward Huniehu & 558 & $46.0 \%$ & $*$ & & \\
\hline & & Joash Ridley Waihura & 237 & $19.5 \%$ & & & \\
\hline & & Solomon Manata & 213 & $17.5 \%$ & & & \\
\hline & & Arsene Waia & 160 & $13.2 \%$ & & & \\
\hline & & Haniel Omokirio & 46 & $3.8 \%$ & & & \\
\hline & East Are' Are Total & & 1,214 & & & & \\
\hline \multirow[t]{7}{*}{1990} & East Honiara & Charles Dausabea & 424 & $41.8 \%$ & * & & \\
\hline & & David Jack Maesua & 217 & $21.4 \%$ & & & \\
\hline & & George Suri Kwanae & 88 & $8.7 \%$ & & & \\
\hline & & Ronald Ila Fugui & 87 & $8.6 \%$ & & & \\
\hline & & Alfred Aihunu & 72 & $7.1 \%$ & & & \\
\hline & & Joseph Firiabae & 67 & $6.6 \%$ & & & \\
\hline & & John Ratu Daofainia & 59 & $5.8 \%$ & & & \\
\hline
\end{tabular}


By-Election Results

\begin{tabular}{|c|c|c|c|c|c|c|c|}
\hline Year & Electorate & Candidate & Vote & Vote (\%) & Winner & Incumbent & Woman \\
\hline \multirow[t]{20}{*}{1985} & Gizo/Kolombangara & Joini Tutua & 521 & $27.4 \%$ & $*$ & & \\
\hline & & George Ngumi & 505 & $26.6 \%$ & & $*$ & \\
\hline & & Chris Taboua & 316 & $16.6 \%$ & & & \\
\hline & & Aquila Talasasa & 227 & $12.0 \%$ & & & \\
\hline & & Franklin Pitakaka & 147 & $7.7 \%$ & & & \\
\hline & & Jackson Piasi & 143 & $7.5 \%$ & & & \\
\hline & & A. Bilikiki & 38 & $2.0 \%$ & & & \\
\hline & & Rejected Votes & 1 & $0.1 \%$ & & & \\
\hline & Gizo/Kolombangara Total & & 1,898 & & & & \\
\hline & West Are' Are & Andrew Nori & 537 & $41.3 \%$ & $*$ & & \\
\hline & & Alfred Aihunu & 470 & $36.2 \%$ & & & \\
\hline & & John Asipara & 292 & $22.5 \%$ & & & \\
\hline & & Rejected Votes & 1 & $0.1 \%$ & & & \\
\hline & West Are' Are Total & & 1,300 & & & & \\
\hline & West Guadalcanal & George Kejoa & 1,655 & $62.7 \%$ & $*$ & $*$ & \\
\hline & & Orlie Torling & 826 & $31.3 \%$ & & & \\
\hline & & Bernard Garo & 110 & $4.2 \%$ & & & \\
\hline & & B. Bara & 46 & $1.7 \%$ & & & \\
\hline & & Rejected Votes & 3 & $0.1 \%$ & & & \\
\hline & West Guadalcanal Total & & 2,640 & & & & \\
\hline \multirow[t]{4}{*}{1974} & Marovo/Kusaghe & Pulepada Ghemu & 755 & $55.1 \%$ & $*$ & & \\
\hline & & Samuel Kuku & 508 & $37.1 \%$ & & $*$ & \\
\hline & & John Wesley Kere & 107 & $7.8 \%$ & & & \\
\hline & Marovo/Kusaghe Total & & 1,370 & & & & \\
\hline
\end{tabular}




\section{Appendix 1 - List of 2010 Electorates}

\begin{tabular}{|c|c|c|c|c|}
\hline Province & Electorate & $\begin{array}{l}\text { Electorate } \\
\text { Code }\end{array}$ & $\begin{array}{r}\text { Total Valid } \\
\text { Votes Cast } \\
\text { in } 2010\end{array}$ & $\begin{array}{r}\text { Registered } \\
\text { voters } 2010\end{array}$ \\
\hline \multirow[t]{2}{*}{ Central } & Nggela & $\mathrm{Ngl}$ & 8,009 & 10,868 \\
\hline & Russells/Savo & RS & 4,306 & 6,892 \\
\hline \multirow[t]{3}{*}{ Choiseul } & East Choiseul & EC & 2,645 & 4,000 \\
\hline & North West Choiseul & NWC & 4,680 & 6,208 \\
\hline & South Choiseul & SC & 3,595 & 5,581 \\
\hline \multirow[t]{8}{*}{ Guadalcanal } & Central Guadalcanal & CG & 4,551 & 6,829 \\
\hline & East Central Guadalcanal & ECG & 4,474 & 7,458 \\
\hline & East Guadalcanal & EG & 4,192 & 7,318 \\
\hline & North East Guadalcanal & NEG & 4,406 & 7,763 \\
\hline & North Guadalcanal & NG & 4,741 & 8,484 \\
\hline & North West Guadalcanal & NWG & 5,361 & 8,238 \\
\hline & South Guadalcanal & SG & 3,876 & 6,131 \\
\hline & West Guadalcanal & WG & 4,274 & 5,652 \\
\hline \multirow[t]{3}{*}{ Honiara } & Central Honiara & $\mathrm{CH}$ & 8,297 & 37,885 \\
\hline & East Honiara & $\mathrm{EH}$ & 8,204 & 39,985 \\
\hline & West Honiara & WH & 7,861 & 32,702 \\
\hline \multirow[t]{3}{*}{ Isabel } & Gao/Bugotu & GB & 3,705 & 5,531 \\
\hline & Hograno/Kia/Havulei & $\mathrm{HKH}$ & 4,133 & 5,749 \\
\hline & Maringe/Kokota & MK & 4,231 & 5,665 \\
\hline \multirow[t]{4}{*}{ Makira/Ulawa } & Central Makira & CMk & 4,007 & 5,510 \\
\hline & East Makira & EMk & 6,436 & 8,473 \\
\hline & Ulawa/Ugi & UU & 2,457 & 3,664 \\
\hline & West Makira & WMk & 4,683 & 6,425 \\
\hline \multirow[t]{14}{*}{ Malaita } & Aoke/Langalanga & $\mathrm{AL}$ & 4,505 & 8,791 \\
\hline & Baegu/Asifola & BA & 4,384 & 10,173 \\
\hline & Central Kwara'ae & $\mathrm{CKe}$ & 6,699 & 9,955 \\
\hline & East Are' Are & EA & 4,601 & 6,651 \\
\hline & East Kwaio & EKo & 5,764 & 10,448 \\
\hline & East Malaita & EMI & 3,977 & 8,231 \\
\hline & Fataleka & $\mathrm{Fa}$ & 5,346 & 10,166 \\
\hline & Lau/Mbaelelea & LM & 9,137 & 16,740 \\
\hline & Malaita Outer Islands & $\mathrm{MOI}$ & 1,615 & 2,913 \\
\hline & North Malaita & NM & 6,211 & 9,188 \\
\hline & Small Malaita & SM & 6,745 & 11,774 \\
\hline & West Are' Are & WA & 3,960 & 6,209 \\
\hline & West Kwaio & WKo & 4,433 & 6,382 \\
\hline & West Kwara'ae & WKe & 7,864 & 13,993 \\
\hline Rennell and Bellona & Rennell/Bellona & RB & 1,840 & 3,386 \\
\hline \multirow[t]{3}{*}{ Temotu } & Temotu Nende & TN & 4,907 & 6,720 \\
\hline & Temotu Pele & TP & 2,914 & 4,512 \\
\hline & Temotu Vatud & TV & 2,382 & 3,830 \\
\hline \multirow[t]{10}{*}{ Western } & Gizo/Kolombangara & GK & 4,782 & 9,078 \\
\hline & Marovo & $\mathrm{Ma}$ & 6,776 & 10,361 \\
\hline & North New Georgia & NNG & 1,913 & 2,705 \\
\hline & North Vella Lavella & NVL & 2,715 & 3,764 \\
\hline & Ranongga/Simbo & RaS & 3,831 & 5,730 \\
\hline & Shortland & Sh & 2,133 & 2,939 \\
\hline & South Vella Lavella & SVL & 3,767 & 5,160 \\
\hline & West New Georgia/Vona Vona & WNG & 5,363 & 9,241 \\
\hline & South New Georgia/Rendova/Tetepari & SNG & 4,006 & 6,138 \\
\hline & Total Solomon Islands & & 235,694 & 448,189 \\
\hline
\end{tabular}


Appendix 2 -Map of Solomon Islands Electorates as of 2010

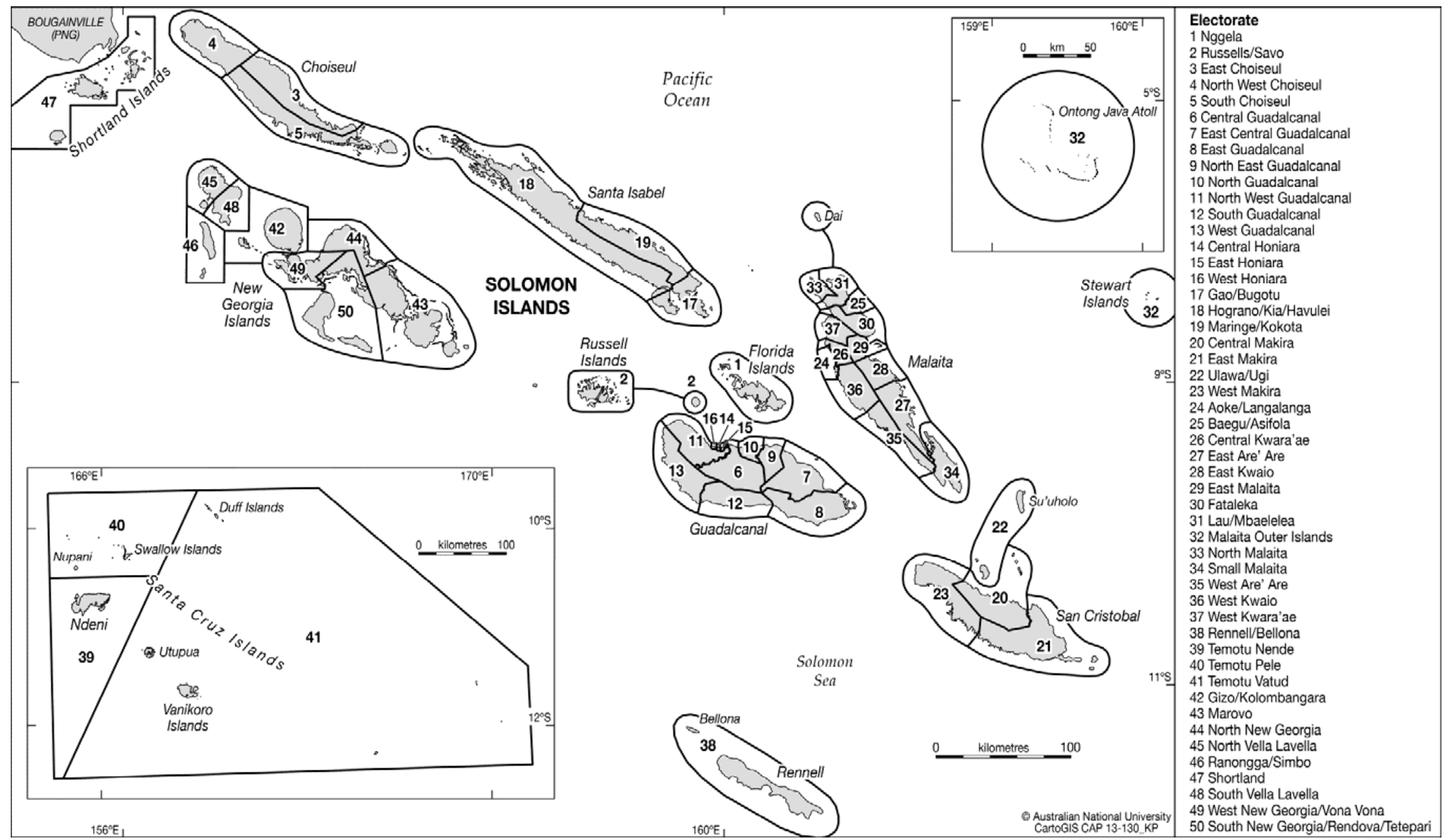

Boundaries changed prior to the 1997 election and before the 1993 election. Download a PDF file mapping older electorates to current ones from: http://wp.me/aSqRs-zC 
